PNL-10592

UC-500

\title{
Hanford 300 Area Steam Transition Preliminary Utility Options Study
}

\section{DISCLAIMER}

N. J. Olson

S. A. Weakley

This report was prepared as an account of work sponsored by an agency of the United States M. J. Berman Government. Neither the United States Government nor any agency thereof, nor any of their employees, makes any warranty, express or implied, or assumes any legal liability or responsibility for the accuracy, completeness, or usefulness of any information, apparatus, product, or process disclosed, or represents that its use would not infringe privately owned rights. Reference herein to any specific commercial product, process, or service by trade name, trademark, manufacturer, or otherwise does not necessarily constitute or imply its endorsement, recommendation, or favoring by the United States Government or any agency thereof. The views and opinions of authors expressed herein do not necessarily state or reflect those of the

June 1995 United States Government or any agency thereof.

Prepared for

the U.S. Department of Energy

under Contract DE-AC06-76RLO 1830

Pacific Northwest Laboratory .

Richland, Washington 99352 


\section{DISCLAIMER}

Portions of this document may be illegible in electronic image products. Images are produced from the best available original document. 


\section{Executive Summary}

The cost of steam in the Hanford 300 Area is approaching $\$ 60$ per million Btu; the cost in industry is $\approx \$ 10$ per million Btu. The cost of steam in the 300 Area is expected to continue to increase because of the age of the central steam system, load decreases, safety requirements, and environmental regulations. The intent of this report is to evaluate options that would more cost-effectively meet the future heating needs of the buildings in the 300 Area. In general, the options fall into two categories: central systems and distributed systems.

A representative option from each category was analyzed using the life-cycle cost analysis (LCCA) techniques mandated by the federal government. The central plant option chosen for evaluation was the existing central steam plant modified to allow continued operation. The distributed option chosen was a dedicated heating system for each building.

Table S.1 is a summary comparison of the quantitative and qualitative features of the two options. The first three quantitative factors were inputs to the LCCA. The total costs shown are the result (output) of the LCCA for each option. The difference between these total costs indicates that a distributed

Table S.1. Summary of Utility Options Analysis

\begin{tabular}{|c|c|c|}
\hline$=$ & $\begin{array}{c}\text { Existing Central } \\
\text { Steam Plant }\end{array}$ & $\begin{array}{c}\text { New Distributed } \\
\text { System }\end{array}$ \\
\hline \multicolumn{3}{|l|}{ Quantitative Factors ${ }^{(2)}$ (\$ millions) } \\
\hline \multicolumn{3}{|l|}{ LCCA Inputs: } \\
\hline - Cost of Capital Improvements ${ }^{(b)}$ & 47.3 & 16.0 \\
\hline - Annual O\&M Cost & 8.3 & 0.8 \\
\hline - Annual Fuel Cost & 1.3 & 1.1 \\
\hline \multicolumn{3}{|l|}{ LCCA Output } \\
\hline - Total Cost ${ }^{(b)}$ & 240.7 & 81.3 \\
\hline \multicolumn{3}{|l|}{ Qualitative Factors } \\
\hline Safety & Marginal & Good \\
\hline Reliability & Marginal & Excellent \\
\hline Flexibility & Poor & Excellent \\
\hline Environmental & Poor & Good \\
\hline Accountability & Marginal & Excellent \\
\hline \multicolumn{3}{|c|}{$\begin{array}{l}\text { (a) For this summary, results are from the 28-yr LCCA study with a 3-yr loan } \\
\text { repayment period for the new distributed system. } \\
\text { (b) These numbers are the LCCA present values. }\end{array}$} \\
\hline
\end{tabular}


system offers a potential savings of $\$ 157$ million. As shown in Table S.1, a distributed system is also superior based on the following five qualitative factors: safety, reliability, flexibility, environmental, and accountability.

To implement the distributed system, an Energy Savings Performance Contract (ESPC) is recommended. This innovative contracting method, which requires no government capital, is quicker than the normal government budgeting cycle and will achieve results.at reduced cost. The competitive ESPC process will also result in the selection of the best distributed system option. 


\section{Contents}

Executive Summary $\ldots \ldots \ldots \ldots \ldots \ldots \ldots \ldots \ldots \ldots \ldots \ldots \ldots \ldots \ldots \ldots$ iii

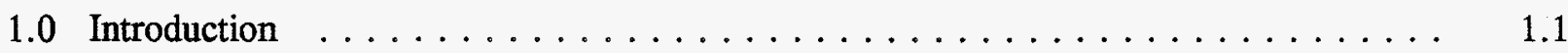

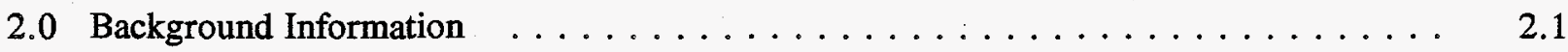

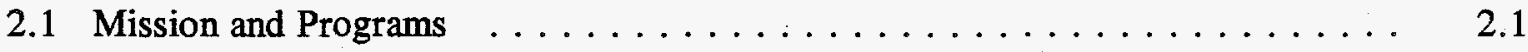

2.2 History of the 300 Area Buildings and Steam Supply $\ldots \ldots \ldots \ldots \ldots \ldots 2.1$

2.3 Historical Supply Arrangements and Problems $\ldots \ldots \ldots \ldots \ldots \ldots .2 .4$

2.4 Utility Supply Objectives $\ldots \ldots \ldots \ldots \ldots \ldots \ldots \ldots \ldots \ldots \ldots \ldots$

3.0 Existing Service Requirements and Supply Arrangements $\ldots \ldots \ldots \ldots \ldots \ldots . .1$

3.1 Current and Past Loads $\ldots \ldots \ldots \ldots \ldots \ldots \ldots \ldots \ldots \ldots \ldots \ldots \ldots \ldots$

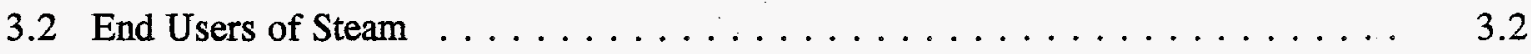

3.3 Existing Supply Arrangement $\ldots \ldots \ldots \ldots \ldots \ldots \ldots \ldots \ldots \ldots \ldots \ldots \ldots$

4.0 Future Service Requirements $\ldots \ldots \ldots \ldots \ldots \ldots \ldots \ldots \ldots \ldots \ldots . \ldots \ldots$

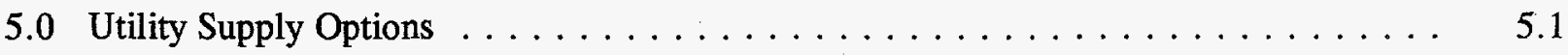

5.1 Identification and Screening of Potential Options $\ldots \ldots \ldots \ldots \ldots \ldots .2$

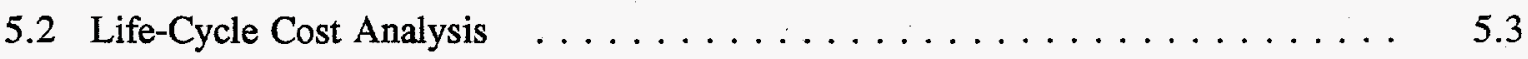

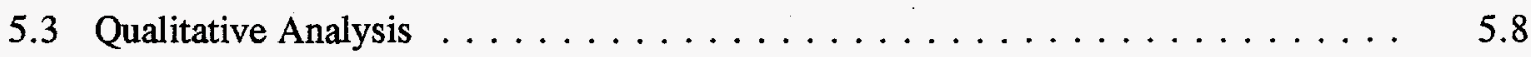

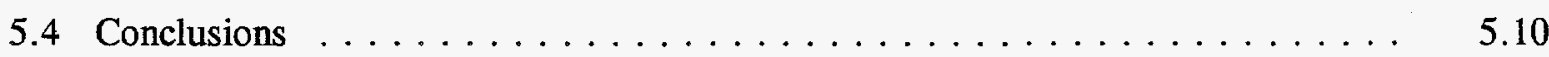

6.0 References $\ldots \ldots \ldots \ldots \ldots \ldots \ldots \ldots \ldots \ldots \ldots \ldots \ldots \ldots \ldots \ldots \ldots \ldots \ldots \ldots .1$

Appendix A: Environmental Considerations $\ldots \ldots \ldots \ldots \ldots \ldots \ldots \ldots \ldots$ A.1

Appendix B: LCCA Assumptions $\ldots \ldots \ldots \ldots \ldots \ldots \ldots \ldots \ldots \ldots \ldots \ldots$ B.1

Appendix C: Life-Cycle Cost Analysis for Existing Central Steam Plant, 13-Year

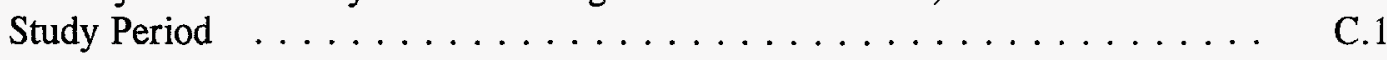


Appendix D: Life-Cycle Cost Analysis for New Distributed Heating System, 13-Year

Study Period and $3-$ Year Loan Repayment Period . . . . . . . . . . . . . D.1

Appendix E: LIfe-Cycle Cost Analysis for New Distributed Heating System, 13-Year

Study Period and 10 -Year Loan Repayment Period $\ldots \ldots \ldots \ldots \ldots$. . . . . . .

Appendix F: Life-Cycle Cost Analysis for Existing Central Steam Plant, 28-Year

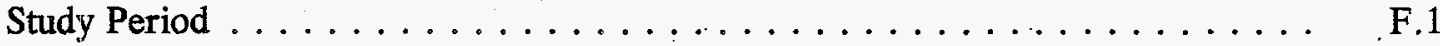

Appendix G: Life-Cycle Cost Analysis for New Distributed Heating System, 28-Year

Study Period and $3-Y e a r$ Loan Repayment Period . . . . . . . . . . . . . . G.1

Appendix H: Life-Cycle Cost Analysis for New Distributed Heating System, 28-Year

Study Period and 10-Year Loan Repayment Period . . . . . . . . . . . . . H 


\section{Figures}

2.1 Locations of Hanford Site Steam Generation Systems $\quad \ldots \ldots \ldots \ldots \ldots \ldots$

2.2300 Area Steam Distribution System $\ldots \ldots \ldots \ldots \ldots \ldots \ldots \ldots \ldots \ldots$

3.1 300 Area Steam - Central Plant Production and O\&M Cost per Delivered MMBtu

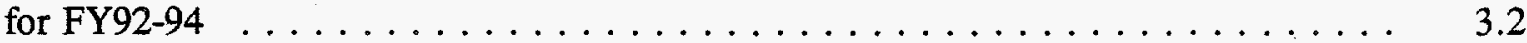

3.2300 Area Steam Production for FY93 $\ldots \ldots \ldots \ldots \ldots \ldots \ldots \ldots \ldots \ldots$

3.3300 Area Average Hourly Steam Production for FY93 $\ldots \ldots \ldots \ldots \ldots$

4.1 300 Area Steam - Central Plant Actual and Projected Production and O\&M Cost per Delivered MMBtu $\ldots \ldots \ldots \ldots \ldots \ldots \ldots \ldots \ldots \ldots \ldots \ldots \ldots$

\section{Tables}

S.1 Summary of Utility Options Analysis $\ldots \ldots \ldots \ldots \ldots \ldots \ldots$ iii

2.1300 Area Steam-Heated Buildings - FY95 $\ldots \ldots \ldots \ldots \ldots \ldots \ldots \ldots \ldots$

3.1300 Area Steam Production - FY92-FY94 $\ldots \ldots \ldots \ldots \ldots \ldots \ldots \ldots \ldots$

4.1300 Area Steam-Heated Buildings - FY97 $\ldots \ldots \ldots \ldots \ldots \ldots \ldots \ldots \ldots$

4.2 Future Steam Requirements $\ldots \ldots \ldots \ldots \ldots \ldots \ldots \ldots \ldots \ldots$

5.1 Comparison of Costs for the $13-$ Year Study $\ldots \ldots \ldots \ldots \ldots \ldots \ldots$

5.2 Comparison of Costs for the $28-Y e a r$ Study $\ldots \ldots \ldots \ldots \ldots \ldots$

5.3 Summary of Utility Options Analysis $\ldots \ldots \ldots \ldots \ldots \ldots \ldots \ldots$ 


\subsection{Introduction}

The purpose of this preliminary options study is to examine various options for providing costeffective heat and process steam to 300 Area facilities. Department of Energy (DOE) Order 4540.1C Utility Acquisition and Management, calls for the "... review of all utility service options available to the Site for better terms and conditions of service, lower rates, or other cost-saving measures." An options study is the beginning of this review process and would provide the basis for developing the Utility Procurement Plan.

The steam infrastructure in the Hanford 300 Area is 50 years old, has reached the end of its useful life, and will require large capital investments over the next decade to continue satisfactory operation. Total operation and maintenance (O\&M) cost (fuel, operations, maintenance, and overhead charges) for the existing central steam system was $\$ 9.01$ million in fiscal year 1994 (FY94) or \$51 per delivered million Btu (\$51/MMBtu) and is projected to be $\$ 9.59$ million (\$58/MMBtu) in FY95. By comparison, the industrial average is less than $\$ 10 / \mathrm{MMBtu}$. In addition to cost-effectiveness, the other driving forces for modernization are safety, environmental compliance, reliability, and the need for increased flexibility because of declining steam loads.

This preliminary utility options study, which was conducted by Pacific Northwest Laboratory (PNL), examines the potential of alternative systems and financing approaches to undertake this modernization. This study is preliminary; the final evaluation of life-cycle cost savings will be completed after the detailed engineering evaluation is conducted.

This preliminary utility options study follows the format identified in Appendix $\mathrm{H}$ of DOE Order 4540.1C, Planning and Preparing a Utilities Options Study of the Utilities Planning and Management manual for DOE facilities. The background information for the current 300 Area situation, including the steam system, is given in Section 2. The existing situation in terms of problems with the steam supply, cost of the steam, and baseline steam production/consumption data is described in Section 3. Forecasted needs for the next few years and changes that may impact the loads in the future are discussed in Section 4. Utility supply options that could meet future loads are evaluated in Section 5. 


\subsection{Background Information}

Background information in this section is presented in the following areas: mission and programs, history of the 300 Area buildings and steam supply, historical supply arrangements and problems, and utility supply objectives.

\subsection{Mission and Programs}

The Hanford site occupies 560 square miles of desert in southeastern Washington State. Shut down in 1989 as a nuclear production site, Hanford has become the DOE complex flagship site for environmental cleanup and restoration. In May 1989, the U.S. Department of Energy, Richland Operations Office (DOE-RL), the State of Washington, and the U.S. Environmental Protection Agency (EPA) signed the Hanford Federal Facility Agreement and Consent Order (known as the Tri-Party Agreement) establishing a 30-year timetable for cleaning up the site.

Because of the change in mission, many of the production facilities have been closed, and more of these buildings are scheduled to be deactivated in the future. The facilities that remain use steam primarily for heating needs.

\subsection{History of the 300 Area Buildings and Steam Supply}

The location of all of the Hanford steam generating systems in relation to the 300 Area is shown in Figure 2.1. The 300 Area steam system boiler plant is located in the 384 Building and is operated by Kaiser-Hanford (ICF-KH), a subcontractor to Westinghouse Hanford Company (WHC). The 300 Area central steam plant is composed of six boilers: three oil-fired (with capacities of $60,000,80,000$ and $100,000 \mathrm{lb} / \mathrm{hr}$ ) and three coal-fired (each $40,000 \mathrm{lb} / \mathrm{hr}$ capacity). The three coal-fired boilers and a coal-handling system were installed in 1986; however, satisfactory operation was not achieved after startup. The coal boilers were shut down and placed in cold standby in March 1989. The oil-fired boilers are currently being used to generate steam and are burning \#6 fuel oil.

A map of the primary steam distribution system in the 300 Area is shown in Figure 2.2. The existing central steam system exports steam at approximately 100 psig to provide space heating, process steam, and hot water to 57 buildings managed by PNL and WHC, the two primary DOE contractors operating in the 300 Area. Steam is the primary heating source for these buildings; most space heating uses 15 psig steam. Steam is required to keep the central steam plant operating, but is not required for emergency loads. 


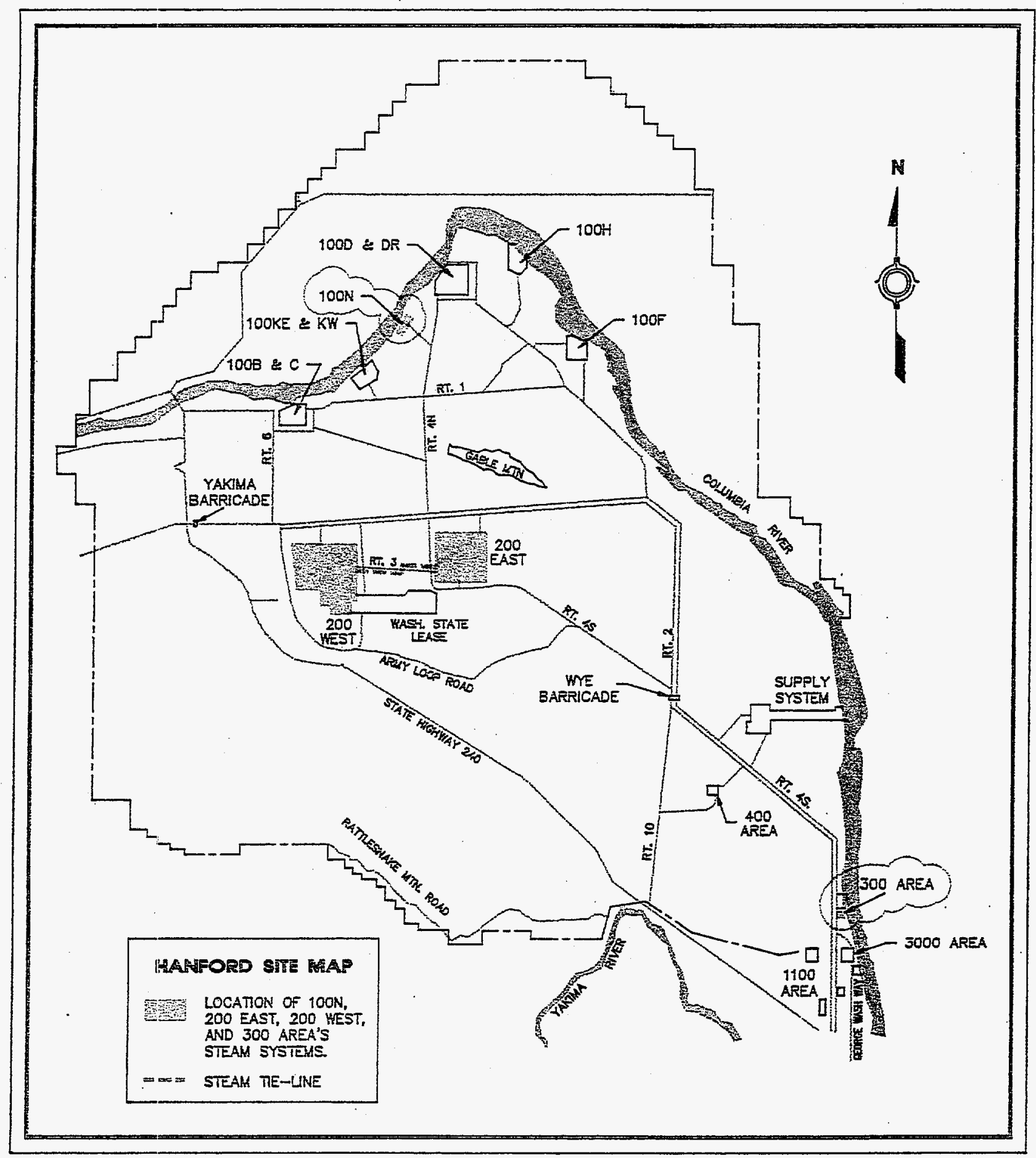

CADFIL: HIP \YOOAREA

Figure 2.1. Locations of Hanford Site Steam Generation Systems 


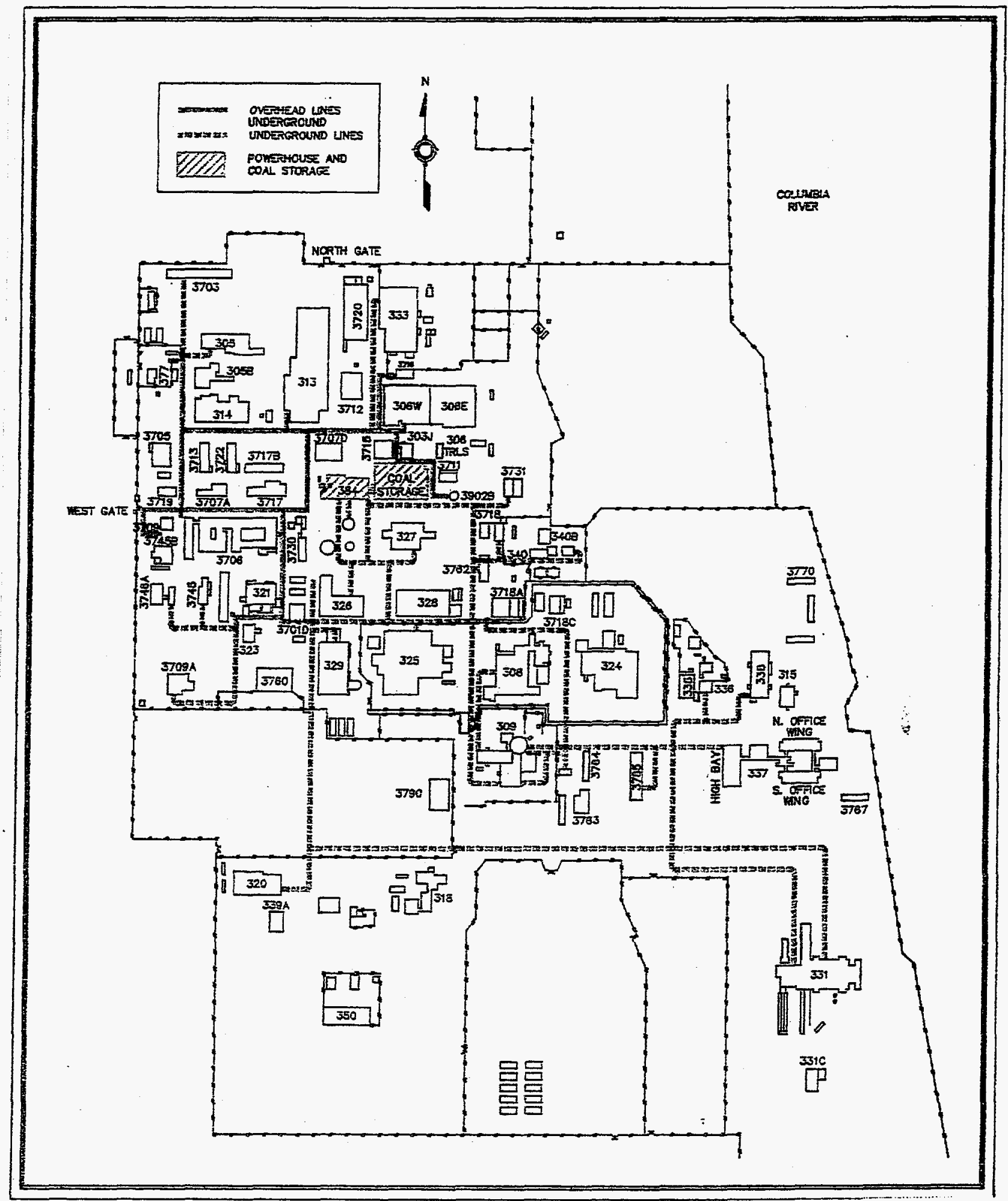

CADFLE: HIP JCOSTEAH(STEAA)

Figure 2.2. 300 Area Steam Distribution System 
A listing of the buildings and contractor occupant (PNL or WHC) currently using central plant steam is given in Table 2.1. PNL currently occupies 26 buildings (64\% of the steam-heated floor space) and WHC occupies 31 buildings (36\%). These buildings include major laboratories and supporting facilities. The buildings range in age from 1943 construction to the present time. The functions performed in these buildings have changed over time, and the buildings were continually retrofitted as needed. Many of the buildings are multi-purpose (i.e., laboratory, office, warehouse, etc.). Many of the buildings use single-pass ventilation systems because activities within the buildings involve radioactive material. In addition, numerous nonsteam heating, ventilating, and air-conditioning (HVAC) systems have been added.

\subsection{Historical Supply Arrangements and Problems}

ICF-KH operates the central steam plant for WHC. Bills for the steam are based on square footage heated, rather than on metered data. Each fiscal year WHC/ICF-KH requests and DOE-RL approves a steam pool budget for operating and maintaining the central steam plant and main distribution system. In FY95, the total charges to the steam system will be $\$ 9.59$ million. This $\$ 9.59$ million is divided into the following three categories: $\$ 3.87$ million for labor; $\$ 1.28$ million for fuel and materials; and $\$ 4.44$ million for various support services and overhead charges. This amount is an increase of $6 \%$ over the $\$ 9.01$ million charged in FY94.

Because of the age of the distribution system and parts of the power plant, system losses are estimated to exceed $42 \%$ and are composed of power plant, distribution system, and condensate return losses. Power plant losses are estimated to be $22 \%$ (based on steam plant records) and do not include combustion losses. Distribution losses from leaks and thermal condensation were estimated at $10 \%$ (ICF-KH 1993). Condensate return losses are $10 \%$ and are due to the fact that only $25 \%$ of the condensate is returned to the central boiler plant (ICF-KH 1993). Thus the entire system currently runs at less then $60 \%$ efficiency.

Steam loads are declining; thus, the existing oil boilers are oversized for current use. According to 1993 steam plant records, there were four months in which the average steam load was below $20 \%$ of the rated load for the smallest oil boiler (as described further in Section 3.1). In the summer, when loads are minimal, the entire system remains pressurized with steam in order to serve any user; as a result, overall efficiency is extremely low.

In the past when outages have occurred, package boilers were brought in to provide back-up steam. The need for back-up steam has occurred more frequently in the last few years as the plant has aged, when safety concerns have shut the plant down for extended periods of time, and when the coal-handling system was shut down.

To sum up, the steam system is $\mathbf{5 0}$ years old, is costly to operate and maintain, is oversized for current uses (and thus is even more inefficient), and has safety liabilities. 
Table 2.1. 300 Area Steam-Heated Buildings - FY95

\begin{tabular}{|c|c|}
\hline $\begin{array}{l}\text { Building } \\
\text { Number }\end{array}$ & Name: \\
\hline $303 \mathrm{~J}$ & Material Storage Building \\
\hline 305 & Hot Cell Verification \\
\hline $306 \mathrm{E}$ & Development, Fab., and Testing Lab. \\
\hline $306 \mathrm{~W}$ & Materials Development Lab. \\
\hline 309 & Office, Shops, Computer Systems \\
\hline 314 & Engineering Devel. Lab. \\
\hline 318 & Radiological Calibrations Lab. \\
\hline 320 & Physical Sciences Lab. \\
\hline 321 & Engineering Develop Lab. \\
\hline 323 & Mechanical Properties Lab. \\
\hline 324 & Waste Tech Engineering Lab. \\
\hline 325 & Applied Chemistry Lab. \\
\hline 326 & Materials Sciences Lab. \\
\hline 327 & Post Irradiation Test Lab. \\
\hline 328 & Plant Operations \\
\hline 329 & Chemical Sciences Lab. \\
\hline 331 & Life Sciences Laboratory I \\
\hline $331 \mathrm{~A}$ & Virology Laboratory \\
\hline $331 \mathrm{~B}$ & Dog Kennel \\
\hline 333 & N-Fuel Manufacturing \\
\hline 337 & Tech. Management Center \\
\hline $337 \mathrm{~B}$ & Concrete/Steel \\
\hline 340 & Waste Retent. Neutral. and Load Out \\
\hline $340 \mathrm{~A}$ & Waste Retent. Neutral. and Load Out \\
\hline 377 & Steam Generator Exam Facility \\
\hline 382 & Pumphouse (Fire/Water) \\
\hline $382 \mathrm{~B}$ & Pumphouse \\
\hline 384 & 300 Area Steam Plant $t^{(a)}$ \\
\hline $3506 \mathrm{~A}$ & Powerhouse Maint. Shop \\
\hline 3702 & Offices \\
\hline 3703 & Offices \\
\hline 3705 & Photography \\
\hline 3706 & Information Services \\
\hline $3707 \mathrm{~B}$ & Power House Offices \\
\hline $3707 \mathrm{C}$ & Safeguards \& Security Maint. Shop \\
\hline 3708 & Radioanalytical Lab. \\
\hline 3709 & Paint and Sign Shop \\
\hline $3709 \mathrm{~A}$ & Fire Station \\
\hline $3710 \mathrm{~A}$ & Oil/Solvent Storage \\
\hline 3711 & Maintenance Storage \\
\hline 3715 & Carpenter Shop \\
\hline 3717 & Equipment Warehouse \\
\hline $3717 \mathrm{~B}$ & Standards Lab. \\
\hline 3718 & Mechanical Support \\
\hline 3718 A\&B & Lab Equip. Central Pool \\
\hline 3720 & Environmental Sciences Lab. \\
\hline 3722 & Carpenter Shop \\
\hline 3730 & Gamma Irradiation Fac. \\
\hline 3731 & Lab Equipment Central Pool \\
\hline $3731 \mathrm{~A}$ & Graphite Machine Shop \\
\hline $3734 \mathrm{~A}$ & Paint \& Solvent Storage \\
\hline 3745 & Radiological Sciences Lab \\
\hline $3745 \mathrm{~B}$ & Positive Ion Accelerator Fac. \\
\hline 3760 & Technical Library \\
\hline 3762 & Technical Security \\
\hline 3764 & Office Building \\
\hline 3765 & Office \\
\hline
\end{tabular}

$\begin{array}{r}\text { Steam-Heated } \\ \text { Area }\left(\mathrm{ft}^{2}\right) \\ \hline 3,652 \\ 13,800 \\ 46,303 \\ 36,531 \\ 46,708 \\ 28,192 \\ 17,441 \\ 25,515 \\ 25,515 \\ 4,150 \\ 91,481 \\ 144,092 \\ 63,101 \\ 26,925 \\ 38,556 \\ 39,420 \\ 110,000 \\ 2,800 \\ 4,225 \\ 45,420 \\ 70,424 \\ 35,326 \\ 3,570 \\ 1,366 \\ 3,610 \\ 1,151 \\ 1,181 \\ 17,160 \\ 1,700 \\ 8,640 \\ 11,040 \\ 6,971 \\ 184,160 \\ 40,300 \\ 6,030 \\ 6,700 \\ 7,040 \\ 4,027 \\ 3,051 \\ 8,960 \\ 280 \\ 3,200 \\ 4,800 \\ 9,657 \\ 6,972 \\ 3,722 \\ 9,600 \\ 29,030 \\ 5,000 \\ 3,637 \\ 3,200 \\ 3,200 \\ 780 \\ 6,152 \\ 1,740 \\ \hline\end{array}$

(a) 384 Building uses approximately $22 \%$ of the total steam produced.
IFC-KH Steam Study 1993

Estimated Steam Use

\begin{tabular}{|c|c|c|}
\hline Peak (lb/hr) & Total $(1000 \mathrm{lb} / \mathrm{yr})$ & Occupan \\
\hline 159 & 231 & PNL \\
\hline 760 & 1,690 & WHC \\
\hline 2,708 & 6,800 & WHC \\
\hline 3,260 & 8,320 & PNL \\
\hline 1,600 & 4,320 & WHC \\
\hline 838 & 1,240 & PNL \\
\hline 1,567 & 3,780 & PNL \\
\hline 4,158 & 6,690 & PNL \\
\hline 394 & 519 & WHC \\
\hline 522 & 1,900 & PNL \\
\hline 11,361 & 29,100 & PNL \\
\hline 8,290 & 13,300 & PNL \\
\hline 5,418 & 14,200 & PNL \\
\hline 6,890 & 14,800 & PNL \\
\hline 1,717 & 5,810 & WHC \\
\hline 5,100 & 7,500 & PNL \\
\hline 19,900 & 30,100 & PNL \\
\hline 389 & 684 & PNL \\
\hline 358 & 191 & PNL \\
\hline 5,980 & 7,550 & WHC \\
\hline 3,430 & 4,342 & PNL \\
\hline 1,720 & 2,178 & WHC \\
\hline 115 & 166 & WHC \\
\hline 301 & 438 & WHC \\
\hline 700 & 2,970 & WHC \\
\hline 2,930 & 13,650 & WHC \\
\hline 56 & 81 & WHC \\
\hline & & WHC \\
\hline 70 & 102 & WHC \\
\hline 313 & 269 & WHC \\
\hline 295 & 271 & WHC \\
\hline 440 & 1,220 & WHC \\
\hline 1,240 & 1,060 & WHC \\
\hline 46 & 40 & WHC \\
\hline 290 & 249 & WHC \\
\hline 681 & 1,072 & PNL \\
\hline 335 & 487 & WHC \\
\hline 462 & 672 & WHC \\
\hline 15 & 21 & WHC \\
\hline 62 & 90 & WHC \\
\hline 255 & 370 & WHC \\
\hline 841 & 1,688 & WHC \\
\hline 1,307 & 552 & WHC \\
\hline 120 & 174 & WHC \\
\hline 571 & 831 & PNL \\
\hline 3,316 & 8,535 & PNL \\
\hline 231 & 336 & WHC \\
\hline 257 & 373 & PNL \\
\hline 943 & 2,370 & PNL \\
\hline 943 & 2,370 & PNL \\
\hline 53 & 77 & WHC \\
\hline 443 & 645 & PNL \\
\hline 340 & 487 & PNL \\
\hline 973 & 3,320 & PNL \\
\hline 324 & 349 & PNL \\
\hline 334 & 486 & PNL \\
\hline 931 & 1,360 & WHC \\
\hline & & \\
\hline
\end{tabular}




\subsection{Utility Supply Objectives}

The utility supply objectives should be to ensure utility supplies, at the lowest possible cost and at minimal risk of inadequate supply. Minimizing this risk will usually increase the cost of the utilities. Further compounding the risks are factors that influence supply requirements (e.g., mission changes), adequacy, and costs that may change over time.

To analyze the costs associated with utility decisions, one must evaluate the utility service costs over the entire period or life-cycle during which the utility service arrangements will be affected by the decision. All costs (both capital and operating) should be accounted for and discounted using government-approved guidelines established for life-cycle costing. This approach was used in this study and is described in Section 5.

The first step is to analyze the risk of inadequate supply or excessive cost for each alternative. After this analysis, program staff and management must select among the alternatives by evaluating the trade-offs between lower costs and the risks of adverse outcomes, either in the form of supply risks or the risk of incurring much higher costs in the future.

To summarize, the planner's objective must be one of minimizing the risk of adverse outcomes by improving flexibility while still obtaining an adequate and reliable utility supply at reasonable cost. A comprehensive cost/risk analysis cannot be performed until a detailed engineering study is completed, the best system option chosen, and fuel options and potential suppliers identified. 


\subsection{Existing Service Requirements and Supply Arrangements}

Past and current use of central plant steam in the 300 Area is addressed in this section. Included in this discussion is information on demand and consumption, end users, costs of the service, and the overall assessment of the current service.

\subsection{Current and Past Loads}

Actual steam production records for FY92-94 and projected steam production and steam plant cost for FY95 are shown in Table 3.1. Examining steam loads earlier than FY92 is not useful because the loads have been decreasing, and comparing between nontypical years (e.g., nontypical heating degree days) is inappropriate. The last typical year in terms of average degree days was FY93. A fatal steam accident in June 1993 caused an extended shutdown period during the low summer load months, but this did not appear to have a significant impact on total steam production.

Table 3.1. 300 Area Steam Production - FY92-FY94

\begin{tabular}{|c|c|c|c|c|}
\hline Production Facts for the Central Plant & $\begin{array}{l}\text { Actual } \\
\text { FY92 }\end{array}$ & $\begin{array}{l}\text { Actual } \\
\text { FY93 }\end{array}$ & $\begin{array}{l}\text { Actual } \\
\text { FY94 }\end{array}$ & $\begin{array}{l}\text { Est. } \\
\text { FY95 }\end{array}$ \\
\hline Annual Heating Degree Days ${ }^{(a)}$ & 4,331 & 5,571 & 4,589 & - \\
\hline Produced (1000 lbs@120 psig) & 252,196 & 271,486 & 256,404 & 241,000 \\
\hline Exported (1000 lbs@120 psig) & 213,369 & 210,064 & 198,394 & 187,000 \\
\hline Delivered (1000 lbs @15 psig) & 192,032 & 189,058 & 178,555 & 168,000 \\
\hline Delivered (MMBtu @15 psig) $)^{(b)}$ & 188,960 & 186,033 & 175,698 & 165,000 \\
\hline Total O\&M Cost of Steam Delivered (\$ Million) & 5.81 & 6.11 & 9.01 & 9.59 \\
\hline Cost of Steam to Customers ( $\$ / M M B t u)$ & 31 & 33 & 51 & 58 \\
\hline \multicolumn{5}{|c|}{$\begin{array}{l}\text { (a) Hanford 30-Year Average Annual Heating Degree Days }=5461 \text {. Definition of Heating } \\
\text { Degree Day is }\left[\Sigma\left(65^{\circ} \mathrm{F}-\mathrm{T}\right)\right] \text { for temperatures }<65^{\circ} \mathrm{F} \text {. } \\
\text { (b) Assuming } 984 \mathrm{Btu} / \mathrm{lb} \text { of steam @ } 15 \text { psig. }\end{array}$} \\
\hline
\end{tabular}

The cost of steam to customers for FY94 of $\$ 9.01$ million (\$51/MMBtu delivered) did not include approximately $\$ 5.3$ million spent to improve operational procedures after a fatal accident in June of 1993. The impact of this accident on total O\&M cost and cost per delivered Btu is shown in Figure 3.1 with the jump in cost between FY93 and FY94. In addition, the $\$ 9.01$ million does not include costs of other capital improvements to the steam system because they are not directly charged to the steam users, but are paid for out of various DOE capital accounts. 


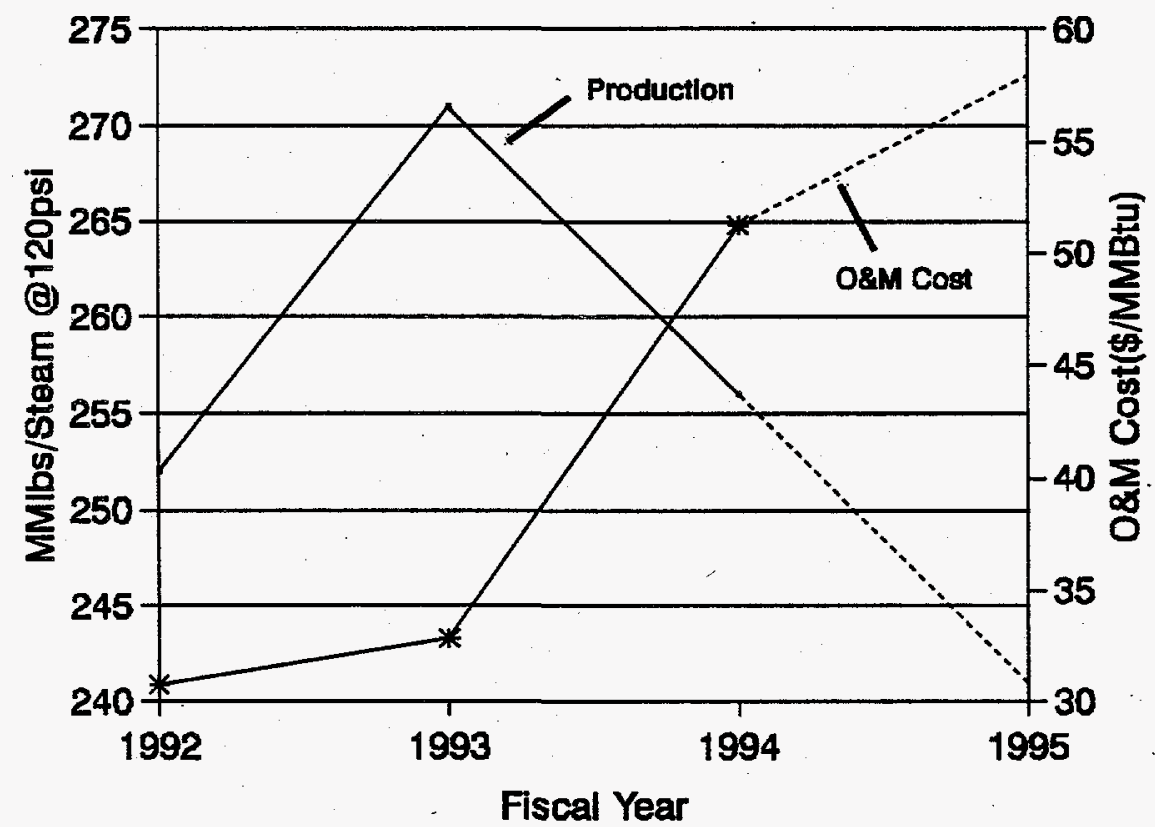

\section{Production * OdM Cost}

Figure 3.1. 300 Area Steam - Central Plant Production and O\&M Cost per Delivered MMBtu for FY92-94

For relative comparisons in Table 3.1, the amount of steam delivered in FY93 and FY94, respectively, was 189 million pounds and 179 million pounds, a decline of $6 \%$. This decline is due to buildings being deactivated and closed down (e.g., the 308 Building), the decline in process steam use in the WHC/ICF-KH buildings, and fewer heating degree days. The decline is expected to continue as buildings are closed and personnel moved from the 300 Area to other facilities or as the building heating systems are removed from central steam to other heating sources.

The use of steam in the 300 Area is seasonal, with peak usage occurring in the December to February time frame. In the summer, parts of the system are taken out of service to fix the steam leaks, and production drops below 6 million pounds per month. The monthly steam production profile for FY93 is shown in Figure 3.2. The average hourly steam production load for FY93 is shown in Figure 3.3. The peak demand for the last few years has been very consistent, with only slight variations because of changes in the outside ambient temperature. The peak demand was estimated to be $\sim 110,000$ pounds of steam per hour (ICF-KH 1993). The ICF-KH study also estimated the peak demands on a building-bybuilding basis as shown in Table 2.1 .

\subsection{End Users of Steam}

Because steam use is not metered at the facilities, there are no historical consumption data for each building. The 1993 ICF-KH study contains an engineering estimate of each building's annual 


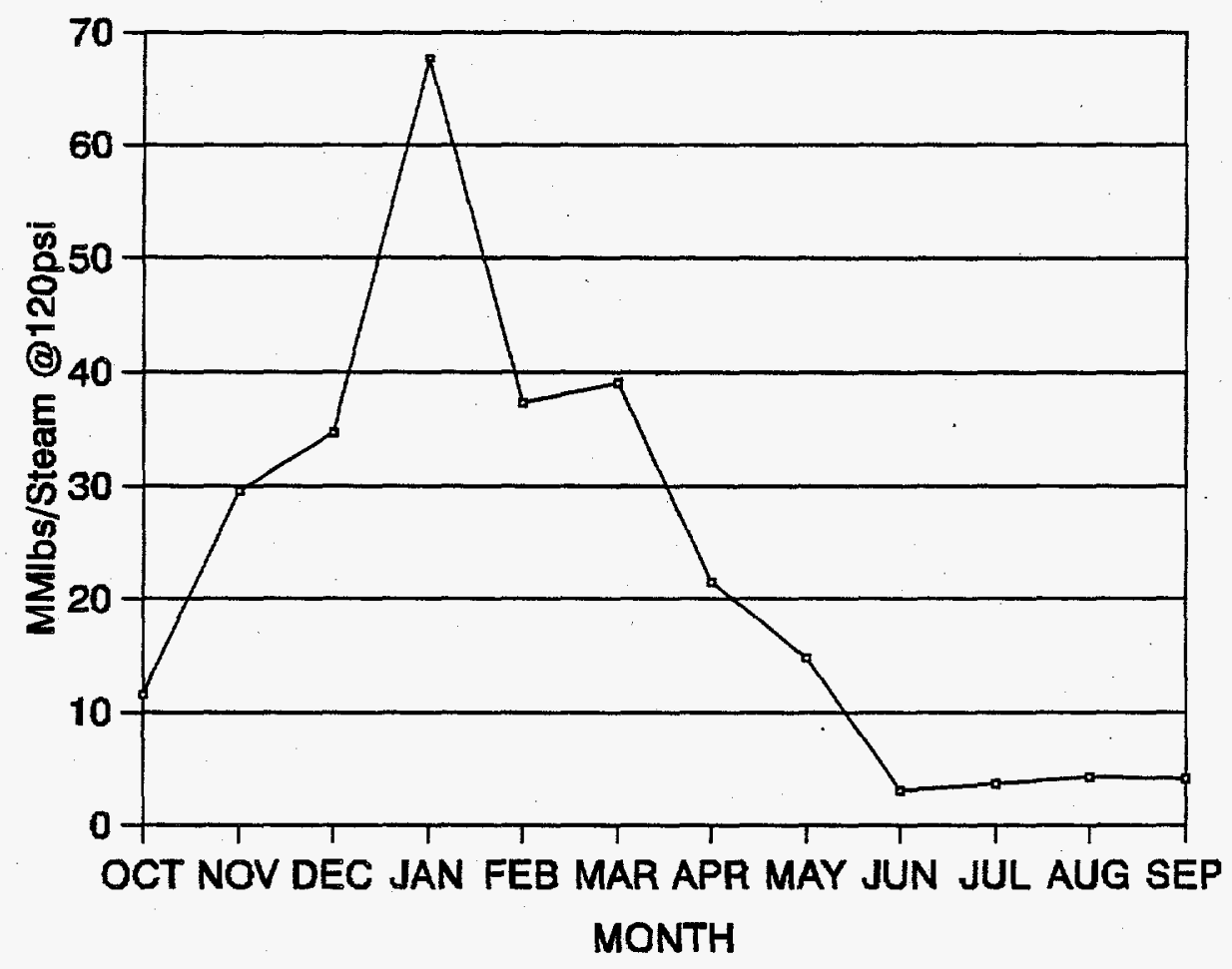

Figure 3.2. 300 Area Steam Production for FY93

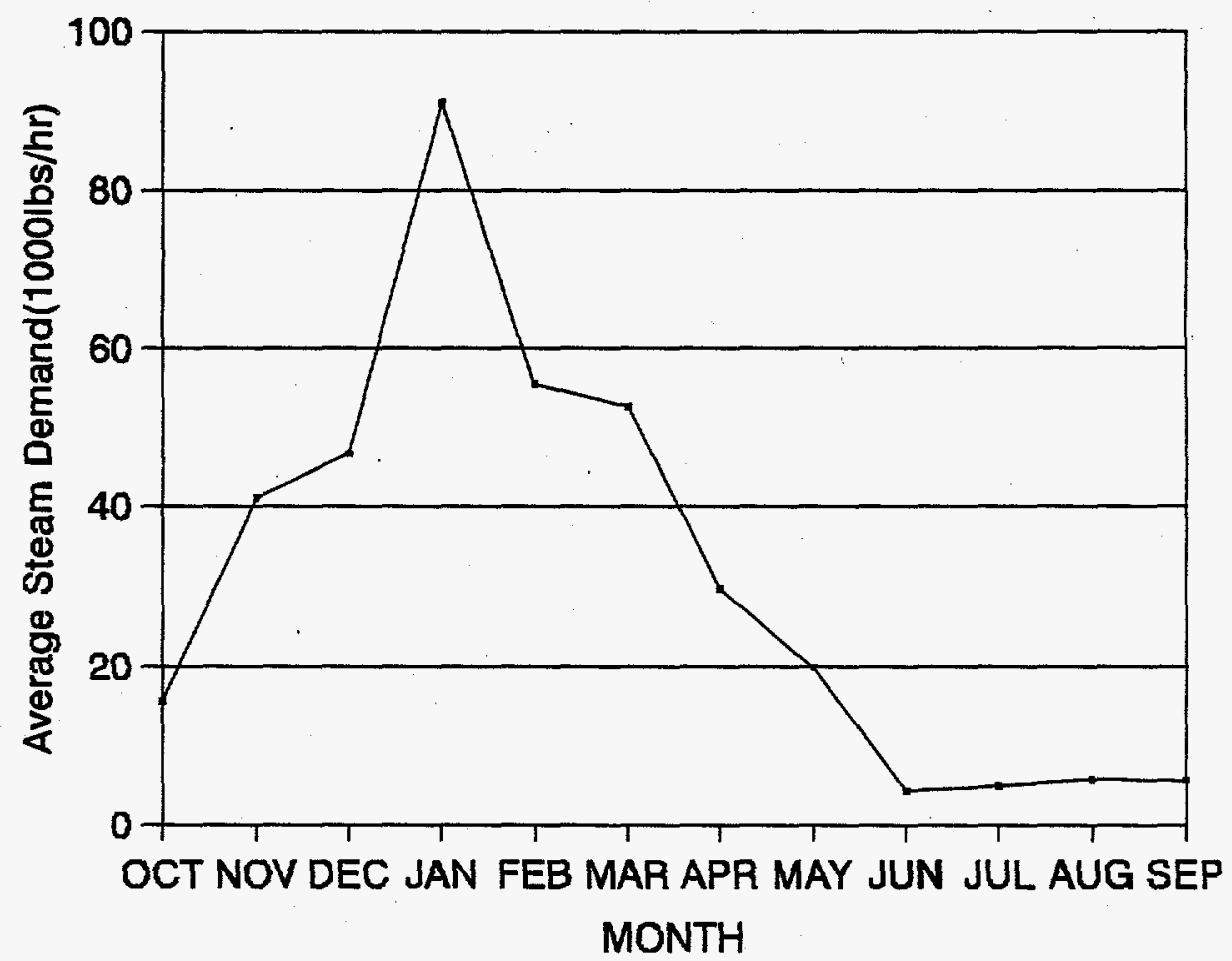

Figure 3.3. 300 Area Average Hourly Steam Production for FY93 
consumption and peak demand. As discussed in Section 2.3, system losses were estimated at $42 \%$ of the steam produced. Of the remaining 58\%, more than $80 \%$ is used for space or building heating needs.

Process uses of steam are not expected to change in the near future, but any changes to the steam supply system need to consider the programmatic requirements for process steam.

\subsection{Existing Supply Arrangement}

The existing supply arrangement is the same as described in the Historical Supply Arrangement and Problems (Section 2.3). 


\subsection{Future Service Requirements}

The current usage pattern of steam is not expected to change in the future. Steam would continue to be used primarily to heat buildings, with a small percentage for process and hot water uses. The usage would peak in the winter and drop off dramatically in the summer.

Although the usage pattern will remain the same, the actual steam consumption is projected to continue to decline. A review was conducted to determine which of the 57 buildings currently using steam (those shown in Table 2.1) will still need steam at the end of FY97. According to the review, 22 PNL and $23 \mathrm{WHC} / \mathrm{ICF}-\mathrm{KH}$ buildings will need heating for the foreseeable future. Thus, the 57 buildings currently using actual plant steam will be reduced to 45 buildings by the end of FY97 (see Table 4.1). This planned reduction will reduce required total steam loads by 17\% (FY97 versus FY93), as shown in Table 4.2 and Figure 4.1.

One effect of this steam load reduction would be to further decrease the efficiency of the boiler plant since the boilers are sized to handle much larger loads. In addition, as the total load declines, the transmission losses also become an ever-increasing percentage of losses because the steam lines must be charged at the same pressure no matter what size load. Given this reduction in steam load and the potential impact of budget reductions causing more facilities to be closed and/or taken off the central steam transmission system, it is safe to assume the decline in steam requirements may be larger than estimated in this section.

Another impact of the decreasing load and efficiency is that the unit cost of steam (\$/MMBtu) will continue to increase. This increase occurs because the variable fuel cost is relatively small compared with the total fixed O\&M cost. This is an example of the existing steam system's inability to costeffectively provide steam in the future. Based on problems with the existing steam system identified in this study, future requirements, not necessarily in order of importance, should include

- Flexibility - meet a changing load without increasing the cost of steam to the user

- Safety - improve the inherent safety of the system

- Reliability - minimize impact due to equipment failure

- Cost - lower the cost of steam to users to be closer to industrial average

- Environmental Impacts - minimize emissions and effluents. 
Table 4.1. 300 Area Steam-Heated Buildings - FY97

\begin{tabular}{|c|c|}
\hline $\begin{array}{l}\text { Building } \\
\text { Number }\end{array}$ & Name \\
\hline $303 \mathrm{~J}$ & Material Storage Building \\
\hline 305 & Hot Cell Verification \\
\hline $306 \mathrm{E}$ & Development, Fab., and Testing Lab \\
\hline $306 \mathrm{~W}$ & Materials Development Lab. \\
\hline 309 & Office, Shops, Computer Systems \\
\hline 314 & Engineering Devel. Lab. \\
\hline 318 & Radiological Calibrations Lab. \\
\hline 320 & Physical Sciences Lab. \\
\hline 323 & Mechanical Properties Lab. \\
\hline 324 & Waste Tech. Engineering Lab. \\
\hline 325 & Applied Chemistry Lab. \\
\hline 326 & Materials Sciences Lab. \\
\hline 327 & Post Irradiation Test Lab. \\
\hline 328 & Plant Operations \\
\hline 329 & Chemical Sciences Lab. 1 \\
\hline 331 & Life Sciences Laboratory I \\
\hline 337 & Tech. Management Center \\
\hline $337 \mathrm{~B}$ & Concrete/Steel \\
\hline 340 & Waste Retent. Neutral. and Load Ou \\
\hline $340 \mathrm{~A}$ & Waste Retent. Neutral. and Load Ou \\
\hline 377 & Steam Generator Exam Facility \\
\hline 382 & Pumphouse (Fire/Water) \\
\hline $382 \mathrm{~B}$ & Pumphouse \\
\hline $3506 \mathrm{~A}$ & Powerhouse Maint. Shop \\
\hline 3705 & Photography \\
\hline $3707 \mathrm{C}$ & Safeguards \& Security Maint. Shop \\
\hline 3708 & Radioanalytical Lab. \\
\hline 3709 & Paint and Sign Shop \\
\hline $3709 \mathrm{~A}$ & Fire Station \\
\hline $3710 \mathrm{~A}$ & Oil/Solvent Storage \\
\hline 3711 & Maintenance Storage \\
\hline 3713 & Carpenter Shop \\
\hline 3717 & Equipment Warehouse \\
\hline $3717 \mathrm{~B}$ & Standards Lab. \\
\hline 3718 & Mechanical Support \\
\hline 3718 A\&B & Lab Equip. Central Pool \\
\hline 3720 & Environmental Sciences Lab. \\
\hline 3730 & Gamma Irradiation Fac. \\
\hline $3734 \mathrm{~A}$ & Paint \& Solvent Storage \\
\hline 3745 & Radiological Sciences Lab. \\
\hline $3745 \mathrm{~B}$ & Positive Ion Accelerator Fac. \\
\hline 3760 & Technical Library \\
\hline 3762 & Technical Security \\
\hline 3764 & Office Building \\
\hline 3765 & Office \\
\hline \multicolumn{2}{|c|}{ Totals Number of Buildings $=45$ ) } \\
\hline
\end{tabular}

Steam Heated Area $\left(\mathrm{ft}^{2}\right)$

3,652

13,800

46,303

36,531

46,708

28,192

17,441

25,515

4,150

91,481

144,092

63,101

26,925

38,556

39,420

110,000

70,424

35,326

3,570

1,366

3,610

1,151

1,181

1,700

6,971

7,040

4,027

3,051

8,960

280

3,200

4,800

9,657

6,972

3,722

9,600

29,030

3,637

780

5,152

6,744

21,700

8,030

8,030

12,160

$1,017,738$
IFC-KH Steam Study 1993

Estimated Steam Use

\begin{tabular}{|c|c|c|}
\hline Peak (lb/hr) & Total $(1000 \mathrm{lb} / \mathrm{yr})$ & Occupant \\
\hline 159 & 231 & PNL \\
\hline 760 & 1,690 & WHC \\
\hline 2,708 & 6,800 & WHC \\
\hline 3,260 & 8,320 & PNL \\
\hline 1,600 & 4,320 & WHC \\
\hline 838 & 1,240 & PNL \\
\hline 1,567 & 3,780 & PNL \\
\hline 4,158 & 6,690 & PNL, \\
\hline 522 & 1,900 & PNL \\
\hline 11,361 & 29,100 & PNL \\
\hline 8,290 & 13,300 & PNL \\
\hline 5,418 & 14,200 & PNL \\
\hline 6,890 & 14,800 & PNL \\
\hline 1,717 & 5,810 & WHC \\
\hline 5,100 & 7,500 & PNL \\
\hline 19,900 & 30,100 & PNL \\
\hline 3,430 & 4,342 & PNL \\
\hline 1,720 & 2,178 & WHC \\
\hline 115 & 166 & WHC \\
\hline 301 & 438 & WHC \\
\hline 700 & 2,970 & WHC \\
\hline 2,930 & 13,650 & WHC \\
\hline 56 & 81 & WHC \\
\hline 70 & 102 & WHC \\
\hline 440 & 1,220 & WHC \\
\hline 290 & 249 & WHC \\
\hline 681 & 1,072 & PNL \\
\hline 335 & 487 & WHC \\
\hline 462 & 672 & WHC \\
\hline 15 & 21 & WHC \\
\hline 62 & 90 & WHC \\
\hline 255 & 370 & WHC \\
\hline 841 & 1,688 & WHC \\
\hline 1,307 & 552 & WHC \\
\hline 120 & 174 & WHC \\
\hline 571 & 831 & PNL \\
\hline 3,316 & 8,535 & PNL \\
\hline 257 & 373 & PNL \\
\hline 53 & 77 & WHC \\
\hline 443 & 645 & PNL \\
\hline 340 & 487 & PNL \\
\hline 973 & 3,320 & PNL \\
\hline 324 & 349 & PNL \\
\hline 334 & 486 & PNL \\
\hline 931 & 1,360 & WHC \\
\hline
\end{tabular}


Table 4.2. Future Steam Requirements

\begin{tabular}{|c|c|c|c|c|c|}
\hline & PNL & WHC & Total & Reduction from FY93 & $\%$ Reduction from FY93 \\
\hline FY93 & & & & - & - \\
\hline No. of Bldgs. & 26 & 40 & 66 & - & - \\
\hline Heated Area $\left(\mathrm{ft}^{2}\right)$ & 770,299 & 544,033 & $1,314,332$ & - & - \\
\hline lbs/hr Peak & 80,765 & 35,324 & 116,089 & - & - \\
\hline $1000 \mathrm{lbs} / \mathrm{yr}$ & 157,216 & 81,690 & 238,906 & - & - \\
\hline \multicolumn{6}{|l|}{ FY95 } \\
\hline No. of Bldgs. & 26 & 31 & 57 & 9 & 13.6 \\
\hline Heated area $\left(\mathrm{ft}^{2}\right)$ & 770,299 & 414,630 & $1,184,929$ & 129,403 & 9.8 \\
\hline lbs/hr Peak & 80,765 & 26,287 & 107,052 & 9,037 & 7.8 \\
\hline $1000 \mathrm{lbs} / \mathrm{yr}$ & 157,216 & 55,210 & 212,426 & 26,480 & 11.1 \\
\hline \multicolumn{6}{|l|}{ FY97 } \\
\hline No. of Bldgs. & 22 & 23 & 45 & 21 & 31.8 \\
\hline Heated area $\left(\mathrm{ft}^{2}\right)$ & 756,874 & 260,864 & $1,017,738$ & 296,594 & 22.6 \\
\hline lbs/hr Peak & 78,132 & 17,788 & 95,920 & 20,169 & 17.4 \\
\hline $1000 \mathrm{lbs} / \mathrm{yr}$ & 151,601 & 45,166 & 196,767 & 42,139 & 17.6 \\
\hline
\end{tabular}

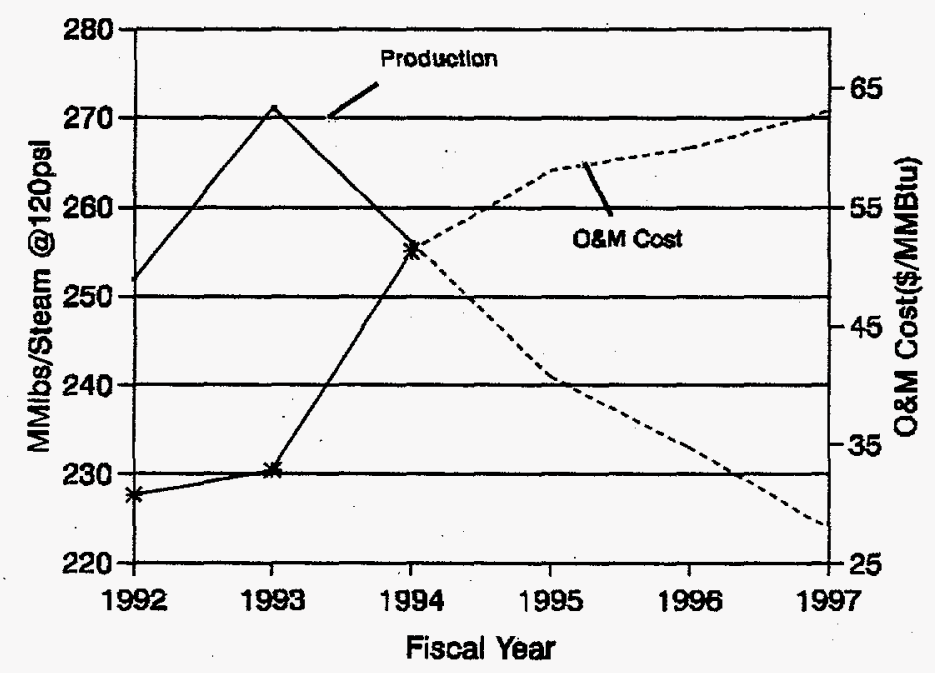

\section{Production *osm cost}

Figure 4.1. 300 Area Steam - Central Plant Actual and Projected Production and O\&M Cost per Delivered MMBtu 


\subsection{Utility Supply Options}

This section identifies and evaluates various system and fuel options to compare with the existing 300 Area central steam system. Because this utility option study is preliminary, the time and cost of identifying all potential alternatives, developing detailed cost estimates, and identifying the very best option through life-cycle cost analysis (LCCA) and qualitative factor analysis were avoided by use of a preferred method: classify the possible options into categories, choose a representative option from each category, and analyze the representative options in detail.

One of the purposes of this chapter is to show the potential cost savings that a distributed system has in the 300 Area. To do so requires the use of LCCA to compare the cost of the operation of the existing system versus a distributed one. The LCCA was performed using the National Institute of Standards and Technology Building Life-Cycle Cost (BLCC) computer program (NIST 1994b) in accordance with the energy price indices and discount factors in the 1995 edition of the federal methodology for LCCA (NIST 1994a) and following the methodology for LCCA in 10 CFR 436. The LCCA used a real discount rate (not including general inflation) of $3 \%$ per year (per the NIST report for 1995) and constant 1995 dollars. This discount rate was used to convert all future costs into an equivalent present value in 1995 dollars.

Section 155 of the Energy Policy Act of 1992 (Public Law 102-486) authorizes the federal government to enter into Energy Saving Performance Contracts (ESPC). ESPCs allow the government to enter into partnerships with industrial companies who use their own capital to install equipment that reduces their customer's energy and O\&M costs. The government pays the ESPC contractor back over time by using part of the savings. This arrangement saves the government money by decreasing costs and allows the government to upgrade the plant without expending capital funds.

The ESPC process is quicker than the normal government budgeting cycle and achieves results at reduced cost without requiring government capital. The ESPC contractor provides the capital, engineering, analysis, construction labor, materials, equipment, and project management, and, many times, the O\&M labor and materials as well. The ESPC contractor guarantees that a certain amount of savings will be achieved annually. Thus, by pursuing a competitive ESPC contract, DOE can have confidence that cost-effective alternatives will be evaluated. At that point, a final utility option study could be done to document the decision-making process.

Regardless of the system and fuel choices ultimately made, several environmental requirements. have to be met. These requirements include the revised Washington Administrative Code (WAC) 173-400 dealing with air emissions of $\mathrm{NO}_{x}, \mathrm{SO}_{2}$, particulates, etc., and WAC 173-401 dealing with enhanced monitoring of stack emissions. These regulations implement the Federal Clean Air Act (see Appendix A). A requirement of connecting the 300 Area sanitary sewer system to the City of Richland 
is that the existing noncontact cooling water and condensate discharges must be eliminated from the sanitary effluent stream to meet EPA regulations. If the State of Washington denies Hanford's application for a soil discharge permit, facilities in the 300 Area will not be allowed to discharge condensate to the soil.

\subsection{Identification and Screening of Potential Options}

The options for supplying heating and process needs in the 300 Area fall into two basic categories: central plant options and decentralized or distributed system options. Each system option has variations depending on which fuel and back-up fuel is chosen. Options in each of these categories are discussed below in more detail. As a result of the analysis in this section, a representative option will be chosen from both the central plant and distributed systems options discussed below.

\section{Central Plant Options}

The central steam plant category has basically three systems options:

- overhaul and upgrade the existing system

- build a.new central plant and upgrade or replace the existing steam supply system

- install a cogeneration plant and upgrade or replace the steam supply system.

All three options will require upgrading or replacing the existing steam supply system. This system is nearly fifty years old, is plagued by steam leaks and $75 \%$ condensate loss, and has reached the end of its design life.

The 1993 Kaiser steam study (ICF-KH 1993) estimated that replacing and burying the aboveground overhead steam supply piping in the north part of the 300 Area (approximately $25 \%$ of the steam supply piping) would cost approximately $\$ 20.5$ million. In addition, the study notes that the condensate return system is in a constant state of repair, is well beyond its design life, and is in extremely poor condition. The estimated cost to upgrade and expand the condensate system to recover up to $90 \%$ of the condensate from the buildings is $\$ 12.9$ million (ICF-KH 1993). As noted previously in Section 2 of this study, the existing boilers are old. Continued operation with either coal or oil will require the use of low-sulphur coal or oil, thus greatly increasing the annual fuel cost, or will require the installation of sulphur scrubbers, at a cost ICF-KH estimates to be $\$ 15$ million (see Appendix A for a more detailed discussion of environmental considerations). Thus, major capital expenditures will be required to enable any central system to meet current environmental and safety standards.

Improvements to the existing system can be made incrementally over time. This method would require careful technical planning and budgeting to minimize the risk of system shutdown or failure. 
Replacement of the entire central steam plant and steam distribution system would have a higher capital cost but could reduce the annual $O \& M$ cost, depending on how the new plant is operated.

The cogeneration option would generate both electricity and steam. According to the Electric Power Research Institute (EPRI 1991), cogeneration is a good candidate only if the marginal price of electricity is higher than 6 cents $/ \mathrm{kWh}$ (Hanford's BPA rate is 2.6 cents $/ \mathrm{kWh}$ ) and thermal loads are constant throughout the year (the 300 Area's thermal loads are highly variable). Thus, cogeneration does not appear to be a viable alternative for providing low-cost steam in the 300 Area.

To meet the Clean Air Act requirements and to obtain an operating permit from the State of Washington, any of the above central plant options would require use of higher cost low-sulphur oil or coal, installation of sulphur scrubbers, or use of natural gas. Based on its lower estimated capital cost, the existing steam plant upgrade/system replacement option will be analyzed in detail as the representative central steam plant option and will also serve as the base case to compare against a distributed system option.

\section{Distributed System Options}

There are numerous distributed system options. Using the ESPC approach, private industry may propose various types of distributed systems. PNL contracted with Johnson Controls, Inc. (JCI) to provide an energy assessment of the buildings in Table 4.1 (JCI 1994).

Given the cost of steam from the existing central plant, JCI concluded that a far more cost-effective option would be a distributed boiler system. JCI recommended either two or three low-pressure natural gas boilers (with propane backup if necessary) located in or next to each of the larger buildings, and conversion to direct gas-fired unit heaters or, in some cases, electrical heating for some of the smaller outlying buildings. High-pressure process steam loads would be met using small spot-boilers installed where needed. Cost estimates for conversion and projected transition schedules were also included. JCl also indicated that the most cost-effective system would probably be some type of distributed boiler system supplying small groups of buildings and, in some cases, converting buildings to hot water rather than steam. According to JCI, this option would require a detailed engineering assessment. The completely distributed boiler system is probably not the most cost-effective solution. However, because it provides an indication of the potential cost savings, this system was chosen to represent the distributed system option.

\subsection{Life-Cycle Cost Analysis}

The two representative options were analyzed using the federal LCCA methodology. Two study periods were chosen: 10 years and 25 years as short- and long-term operational periods, respectively. It was assumed that three years would be required (1995-1997) to transition to a new distributed system using the ESPC approach, giving a total study length of 13 and 28 years. The LCCA methodology requires that financial comparisons between the base case and the alternatives be over the same length 
of time; thus, the central steam plant and the distributed system were each analyzed for 13 and 28 years. It is extremely important that the results of the 13-year studies not be compared with the 28year studies.

For these periods, it was assumed that no major mission changes occur, i.e., building heating needs stay roughly the same. It was also assumed that the 45 buildings shown in Table 4.1 would remain active and heated and that the square footage would remain at approximately $1,018,000 \mathrm{ft}^{2}$. These 45 buildings will require heating, hot water, or process steam in FY97 and would be converted under an ESPC. Details of the cost assumptions for each option are discussed in Appendix B. The inputs and results of each LCCA computer run are shown in Appendices $\mathrm{C}$ through $\mathrm{H}$.

\section{Assumptions and Results for the Existing Central Steam Plant LCCA}

The existing central steam generation and distribution system is assumed to continue to operate over the two study periods (13 and 28 years), given the following major capital upgrades and/or replacements are made. The largest capital project was assumed to be the $\$ 20.5$ million replacement of $25 \%$ of the steam distribution piping in FY2004. The addition of $\mathrm{SO}_{2}$ stack scrubbers in FY98 was assumed to cost $\$ 15$ million. Two condensate return piping projects were assumed: $\$ 3$ million in FY97 and \$12.9 million in FY99. In addition, miscellaneous capital expenses of $\$ 5.8$ million for the 13 -year study or $\$ 14.3$ million for the 28 -year study were assumed.

The annual cost of operation was assumed to remain the same as the estimated FY95 cost. The annual O\&M costs are $\$ 9.59$ million, with a direct labor charge of $\$ 3.87$ million, fuel costs of $\$ 1.28$ million, and other costs of $\$ 4.44$ million (other support and G\&A fees). The $\$ 1.28$ million is for \#6 residual fuel oil ( $\approx 2.5$ million gallons per year); in the BLCC program, this cost is escalated per the DOE fuel price indices for industrial residual oil in the 1995 NIST annual supplement.

The above assumptions were input to the BLCC program, with January 1995 to December 2007 as the study period. All costs were discounted at a $3 \%$ real rate, using end-of-year discounting. The result for the 13-year study was a present value cost of $\$ 130$ million. Of the $\$ 130$ million, $70 \%$ is operating, maintenance, and repair costs; $12 \%$ fuel costs; and $18 \%$ capital replacement costs. For the 28 -year study, the result was a present value cost of $\$ 241$ million, made up of $66 \%$ O\&M, $14 \%$ fuel, and $20 \%$ capital costs.

\section{Assumptions and Results for the Distributed System LCCA}

This alternative case is based on the JCI report that describes a distributed system for the 22 PNL buildings (JCI 1994). The cost of capital and the annual fuel costs for the new system were also derived from the JCI report.

The alternative system that JCI proposed was based on walk-through audits of all the PNL buildings. JCI proposed a mix of gas-fired steam boilers, electric steam boilers, gas-fired duct furnaces, 
gas-fired air-handling units, heat pumps, electric unit heaters, and electric duct coils. The backup fuel for natural gas was propane, and each building had its own heating system. The total cost to design and construct the JCI system was estimated to be $\$ 7.7$ million for the $756,874 \mathrm{ft}^{2}$ of PNL buildings. Applying the same ratio of dollars per heated square foot to the WHC facilities results in a total cost of $\$ 10.3$ million to design and install a distributed system in the 45 buildings. The time required to compete the contract as a DOE procurement was estimated to be one year (FY95). The time needed to install the system was estimated to be two summer seasons (FY96-97). During this time (FY95-97), the existing central plant would be in operation, but would be closed at the beginning of FY98 or earlier.

It was assumed that the increased electricity load could be met by the existing electrical transmission and distribution (T\&D) system in the 300 Area. Cascade Natural Gas, Inc., the local distribution company estimated the cost of extending a natural gas pipeline into the 300 Area to be $\$ 2.5$ million. In addition to the above costs, a contingency equal to $20 \%$ of the $\$ 12.8$ million capital cost was added (\$2.6 million).

In addition to the total implementation cost of $\$ 15.4$ million (including $20 \%$ contingency), there will be finance charges until the capital is paid off. A real interest rate of $8.1 \%$ for this charge was assumed. Higher or lower interest rates simply extend or decrease the payoff period. The entire amount is assumed to be needed at the start of construction, and no payments are made until the new system is operational in its entirety (1998). It was also assumed that the entire implementation cost is carried for one year (FY97) before the central steam plant is terminated and actual savings begin. Two loan repayment cases were calculated. The first was that the new system is paid off over the next 3 years in annual installments. Hence, the interest is applied to the full amount for one year (FY97) and to a declining balance for the next three years (FY98-2000) during the repayment period. The second case was for a repayment period of 10 years (FY98-2007).

The operational scenario assumed for the LCCA is detailed in Appendix B. A total O\&M cost (excluding fuel) of $\$ 802,000 /$ year was assumed for the whole 300 Area; this assumption is based on JCI's estimates. This figure is expected to decrease when more information about future requirements is received from ICF-KH. Our objective at this point is to estimate costs conservatively and then improve the estimates when the detailed engineering analysis is completed for all buildings.

The annual cost of fuel for the distributed system was also based on the JCI report. JCI estimated that 1.9 million therms of natural gas and $730,000 \mathrm{kWh}$ of electricity would be needed annually to heat the PNL buildings. Applying this same ratio over the entire 300 Area results in an annual need for 2.54 million therms of natural gas and $985,000 \mathrm{kWh}$ of electricity. Using Cascade's estimate of $\$ 0.42 /$ therm for natural gas, the cost of natural gas per year is estimated at $\$ 1.067$ million. Using the current BPA electricity rate in the 300 Area of $\$ 0.026 / \mathrm{kWh}$, the annual cost of electricity is estimated to be $\$ 26,000$. Over the study period, the fuel costs were escalated using the indices for natural gas and electricity in the NIST annual supplement. 
The above assumptions for the operating scenario were input to the BLCC program with January 1995 as the start date. In FY98, the central steam plant is terminated and new (distributed) system costs are incurred over the next 10 or 25 years. All costs were discounted at a $3 \%$ real rate using endof-year discounting.

The result for the 13-year study and the 3-year loan repayment case was a present value of $\$ 55.9$ million. Of the $\$ 55.9$ million, $50 \%$ is the cost to operate and maintain (including fuel costs) the existing central steam plant for the first 3 years of the study period; $30 \%$ is the cost of operating and maintaining the new system (including fuel costs); and $20 \%$ is the cost of capital payments. The result for the 13-year study and the 10-year loan repayment case was a present value of $\$ 58.6$ million. Of the $\$ 58.6$ million, $48 \%$ is the cost to operate and maintain the existing plant; $28 \%$ is the cost of operating and maintaining the new system; and $24 \%$ is the cost of capital payments.

The result for the 28-year study and the 3-year loan repayment case was a present value of $\$ 81.3$ million. Of the $\$ 81.3$ million, $35 \%$ is O\&M costs for the existing steam plant for 3 years; $45 \%$ is the O\&M cost of the new system; and $20 \%$ is the cost of capital payments. The result for the 28 -year study and the 10-year loan repayment case was a present value of $\$ 84.1$ million. Of the $\$ 84.1$ million, $33 \%$ is O\&M costs for the existing steam plant; $45 \%$ is the O\&M cost of the new system; and $22 \%$ is the cost of capital payments.

\section{Summary of LCCA Results}

Table 5.1 is a detailed comparison of the present value (PV) costs for the existing steam plant and the distributed system options for the 13-year study. Note that most of the savings (81\% of the savings for the 3-year repayment case and $84 \%$ for the 10-year repayment case) is due to reduced O\&M cost for the new system.

Table 5.1. Comparison of Costs (Present Value based on LCCA) for the 13-Year Study

\begin{tabular}{||l|c|c|c|c|c||}
\hline \multirow{2}{*}{ Cost Categories } & & \multicolumn{2}{|c|}{$\begin{array}{c}\text { Distributed System } \\
\text { (\$million) }\end{array}$} & \multicolumn{2}{c|}{$\begin{array}{c}\text { Savings from Distributed } \\
\text { System (\$million) }\end{array}$} \\
\cline { 3 - 6 } & Existing Plant & $\begin{array}{c}\text { 3-Year } \\
\text { (\$million) }\end{array}$ & $\begin{array}{c}10 \text {-Year } \\
\text { Repayment }\end{array}$ & $\begin{array}{c}\text { 3-Year } \\
\text { Repayment }\end{array}$ & $\begin{array}{c}10 \text {-Year } \\
\text { Repayment }\end{array}$ \\
\hline Operation and Maintenance & 90.5 & 30.8 & 30.8 & 59.7 & 59.7 \\
\hline Fuel & 16.3 & 13.9 & 13.9 & 2.4 & 2.4 \\
\hline Capital & 23.1 & 11.2 & 13.9 & 11.9 & 9.2 \\
\hline Total & 129.9 & 55.9 & 58.6 & 74.0 & 71.3 \\
\hline \hline
\end{tabular}


Of the $\$ 44.7$ million in O\&M and fuel costs for the new distributed system, $\$ 28.2$ million (63\%) is incurred in the first 3 years when the existing central plant is still operating. Therefore, it would be prudent to install the new distributed system as soon as possible to begin accruing the cost savings from closing the central plant.

A similar analysis of Table 5.2 for the 28 -year study also shows that most of the savings (77\% of the savings for the 3 -year repayment case and $78 \%$ for the 10 -year repayment case) is again due to reduced O\&M costs for the new system. Of the $\$ 65.3$ million in O\&M and fuel costs for the new distributed system, $\$ 28.2$ million (43\%) is incurred in the first 3 years when the existing central plant is still operating. Regardless of the study length, a significant amount of savings will result if the central steam plant is shut down as soon as possible.

As shown in Tables 5.1 and 5.2, the choice of a 10-year loan repayment period versus a 3-year loan repayment period would add $\$ 2.8$ million to the total present value cost regardless of the length of the study period. As can also be seen in both tables, the total present value saving is greater than the total present value cost of installing and operating the new distributed systems, regardless of the loan repayment length or study period. An ESPC would allow the transition to a new distributed system much faster than is possible under the normal government budgeting/procurement cycle. As noted above, it was assumed that under an ESPC the total design/build cycle will result in an operating system within 3 years. This cycle compares to a 7- to 10-year cycle under the normal DOE budgeting/ procurement system. Even though DOE will have to pay the ESPC contractor/financier's interest on the capital invested, this cost is more than offset by the $\approx \$ 7.7$ million reduction in annual O\&M costs after the existing central steam system is shut down.

Table 5.2. Comparison of Costs (Present Value based on LCCA) for the 28-Year Study

\begin{tabular}{||l|c|c|c|c|c||}
\hline \multirow{2}{*}{ Cost Categories } & \multirow{2}{*}{$\begin{array}{c}\text { Existing } \\
\text { Plant } \\
\text { (\$million) }\end{array}$} & \multicolumn{2}{|c|}{$\begin{array}{c}\text { Distributed System } \\
\text { (\$million) }\end{array}$} & \multicolumn{2}{c|}{$\begin{array}{c}\text { Savings from Distributed } \\
\text { System (\$million) }\end{array}$} \\
\cline { 3 - 6 } & $\begin{array}{c}\text { 3-Year } \\
\text { Repayment }\end{array}$ & $\begin{array}{c}\text { 10-Year } \\
\text { Repayment }\end{array}$ & $\begin{array}{c}\text { 3-Year } \\
\text { Repayment }\end{array}$ & $\begin{array}{c}\text { 10-Year } \\
\text { Repayment }\end{array}$ \\
\hline Operation and Maintenance & 159.7 & 37.4 & 37.4 & 122.3 & 122.3 \\
\hline Fuel & 33.7 & 27.9 & 27.9 & 5.8 & 5.8 \\
\hline Capital & 47.3 & 16.0 & 18.8 & 31.3 & 28.5 \\
\hline Total & 240.7 & 81.3 & 84.1 & 159.4 & 156.6 \\
\hline
\end{tabular}




\subsection{Qualitative Analysis}

In addition to the quantitative analysis shown in Table 5.1 and 5.2, five qualitative factors were compared for the two options. An analysis for each qualitative factor is discussed below. The qualitative factors and the comparison are not affected by which study or payback period scenario is used for the distributed system.

\section{Safety}

The existing central steam plant is a medium-pressure generation system $(\approx 120 \mathrm{psig})$, while the alternative would be a combination of new low-pressure (15 psig) steam boilers in the new system and some nonsteam heating systems. The use of low-pressure steam boilers decreases the risk of harmful accidents. The existing distribution system is also very old, operates at the same high pressure as the steam plant, and is very long. In addition, it has multiple steam traps, valves, fittings, etc. The new systems are located next to or in the buildings being supplied with heat, thus reducing the size of the distribution system. The low pressure of the steam lines, as well as the fact that some systems do not use steam at all, reduces not only the probability, but the consequences, of an accident.

The safety of the existing system was determined to be marginal because of its use of mediumpressure steam, its age and condition, and its safety history. The new distributed system should have a good safety rating because of its use of low-pressure steam, greatly reduced distribution piping, and newness. An excellent safety rating could only be achieved by eliminating the use of steam.

\section{Reliability}

The existing steam generation system has back-up boilers in place, but they too are old and oversized for the loads required and are therefore inefficient to operate. The distribution system is 50 years old. It has some redundant loops in case certain parts of the system are out of service; other critical parts of the distribution system have no back-up or redundancy. If these fail, no heat will be sent to the buildings on that portion of the line. The distribution system has back-up systems (propane for natural gas systems and redundant electrical service for electrical systems) that are properly sized for the loads to be served. Each of the boiler systems that $\mathrm{JCI}$ costed in its estimate has two boilers per building, with each boiler capable of providing $60 \%$ of the heating load. Under most weather conditions, building comfort could be maintained should one boiler fail. The physical proximity of the boilers and other heating systems to the end users greatly reduces the length of the distribution system needed, thus increasing the system's reliability.

The reliability of the existing system was determined to be marginal because a problem in the central boiler plant or in the main distribution system would affect all user facilities. The new distributed system has back-up boilers; thus, an equipment problem would only affect a single facility. Therefore the new system's reliability was rated excellent. 


\section{Flexibility}

The existing steam plant boilers are oversized for the current steam loads. Given the projected declining loads (discussed in Section 4), the boilers will become even more oversized and inefficient. Thus the existing system is not able to efficiently match steam production to demand. In fact, during four months of the year, the steam losses in the system are more than $80 \%$ of the total steam produced. In contrast, the distributed system will have multiple boilers, sized for each building's actual load, and controlled by energy management systems that monitor changes in building loads as they occur. The distributed system will have only a minimum of distribution losses. Also, if buildings are shut down or modified, the remaining buildings will continue to operate efficiently without absorbing a large share of fixed costs. Thus, the flexibility of the existing system was rated poor, while the new distributed system was rated excellent.

\section{Environmental}

At the present time, \#6 residual fuel oil is being used in the central steam plant. As mentioned earlier, the use of this oil in the future would incur a cost of $\approx \$ 15$ million to install scrubbers to remove sulphur. For energy security reasons, i.e., dependence on foreign sources, the federal government discourages the use of oil.

The existing system requires copious amounts of water due to the small amount of condensate returned to the boiler plant. The majority of the condensate is sent to the drain, which results in a disposal problem for the sewer system.

The JCI report estimated the distributed system would reduce the emission of carbon monoxide by $69.2 \%$, sulphur oxides by $99.95 \%$, and particulates by $98.5 \%$. These reductions are due to switching from oil to natural gas for most of the heating needs. The installation of electrical heating systems in a few buildings also reduces environmental emissions. The increase in overall heating system efficiency of about $30 \%$, due to eliminating the current distribution system losses, also results in less emissions. The distributed systems will be closed-loop systems, thus eliminating most condensate discharge to the sewer.

The existing system was rated poor for environmental impacts from high air emissions, high water consumption, and large quantities of liquid effluent. The new natural-gas-fired system was rated good because it greatly reduces the above environmental problems.

\section{Accountability}

The existing system has inadequate or nonexistent metering at the building level. Customers are billed on a per square foot of heated space basis, rather than on their actual steam usage. This system offers the users no incentive to conserve energy. In fact, those that do conserve are not rewarded at all; hence, the accountability was rated marginal. By generating heat locally, the distributed system 
would allow each building to be billed for exactly what it uses. Therefore, any conservation efforts undertaken in the building would be credited on the bill for that building. The new system makes each building accountable for its own heating needs and encourages energy conservation; it was rated excellent as compared with the existing system.

\subsection{Conclusions}

The results of the quantitative and qualitative analysis of the existing central steam plant and a new distributed system are presented in Table 5.3. The present value of the capital investment for the new distributed system is only $34 \%$ of that required to keep the existing steam plant operational for the next 28 years. The annual O\&M cost for the new system would be only one-tenth of the present O\&M cost. This savings is the largest obtained from installing the new distributed system, even through the annual fuel costs are similar. The present value of the total cost of the distributed system over 28 years is only

Table 5.3. Summary of Utility Options Analysis

\begin{tabular}{|l|c|c||}
\hline & $\begin{array}{c}\text { Existing Central } \\
\text { Steam Plant }\end{array}$ & $\begin{array}{c}\text { New Distributed } \\
\text { System }\end{array}$ \\
\hline Quantitative Factors ${ }^{(\mathbf{a})}$ (\$ millions) & & \\
\hline LCCA Inputs: & & \\
\hline - Cost of Capital Improvements & \\
\hline$\bullet$ Annual O\&M Cost & 47.3 & 16.0 \\
\hline$\bullet$ Annual Fuel Cost & 8.3 & 0.8 \\
\hline LCCA Outputs: & 1.3 & 1.1 \\
\hline- Total Cost ${ }^{(\mathbf{b})}$ & & \\
\hline Qualitative Factors & 240.7 & 81.3 \\
\hline Safety & & \\
\hline Reliability & Marginal & Good \\
\hline Flexibility & Marginal & Excellent \\
\hline Environmental & Poor & Excellent \\
\hline Accountability & Poor & Good \\
\hline (a) For this summary, results are from the 28-yr LCCA study with a \\
3-year loan repayment period for the new distributed system. \\
(b) These numbers are the LCCA present values. & \\
\hline
\end{tabular}


one-third of the cost of the existing steam plant. As previously discussed, $35 \%$ of the total present value cost of the distributed system is due to the cost of operating the existing steam plant for the first 3 years while transitioning to the new system.

The results of the qualitative analysis are also shown in Table 5.3. The existing central steam plant had ratings of either marginal or poor for all five qualitative factors. The new distributed system had ratings of either good or excellent for the same five factors.

The results of this preliminary utility options study show a large potential for cost savings if a distributed heating system is installed in the 300 Area and the existing central steam plant shut down. This option can be most quickly and cost-effectively implemented by issuing a Request For Proposals (RFP) for an ESPC as soon as possible. In addition to offering larger cost savings, the new distributed system is superior to the existing system based on the five qualitative factors considered. 


\subsection{References}

U.S. Department of Energy (DOE). DOE Order 4540.1C, Utility Acquisition and Management, June 8, 1992.

10 CFR 436, Federal Energy Management and Planning Programs, April 11, 1994, Amendment (Notice of Proposed Rulemaking for Energy Savings Performance Contracts).

Electric Power Research Institute (EPRI). October 1991. Customer Purchase Criteria for Small-Scale Cogeneration, EPRI CU-7539, Palo Alto, California.

Johnson Controls, Inc., (JCI). December 20, 1994. "Transition of Heating Utility and Energy Assessment." PNL Contract No. 217420-A-K, Rev. 1, Pacific Northwest Laboratory, Richland, Washington.

Kaiser Hanford (ICF-KH). 1993. 300 Area Steam Plant Shutdown Alternatives Study. WHC-SD-LL-ES-035, Rev 0, December 1993, Kaiser Hanford, Richland, Washington.

Kaiser Hanford (ICF-KH). 1994. 300 Area Steam Plant Natural Gas Use Study. WHC-SD-L201-ES--001, Rev. 1, Kaiser Hanford, Richland, Washington.

National Institute of Standards and Technology. 1994a. Energy Price Indices and Discount Factors for Life Cycle Cost Analysis 1995. NISTIR 85-3273-9, Rev. 10/94. Washington, D.C.

National Institute of Standards and Technology. 1994b. NIST Building Life Cycle Cost (BLCC) Computer Software Program. Washington, D.C.

Pacific Northwest Laboratory. 1992. Analysis and Decision Document in Support of Acquisition of Steam Supply for the Hanford 200 Area. PNL-7991/UC-500, Pacific Northwest Laboratory, Richland, Washington. 


\section{Appendix A}

\section{Environmental Considerations}




\section{Appendix A}

\section{Environmental Considerations}

The following are excerpts from the 300 Area Steam Plant Natural Gas Use Study (ICF-KH 1994). These excerpts contain a discussion of air emissions requirements on the existing central steam plant as it is currently operating and on a plant modified to use natural gas.

\section{Environmental Requirements for the Existing Steam Plant}

"The coal-fired boilers are provided with ash removal equipment. The ash is hydraulically transported to a lined disposal pond. Boiler emissions (coal and oil fired) are kept within limits agreed upon with the State of Washington.

The existing coal- and oil-fired boiler sources are not registered with Ecology. No permitting has been required for these sources. : A baghouse system installed for the existing coal-fired boilers controls the particulate emission. The emission control system for these boilers is designed primarily to achieve the $20 \%$ or less stack opacity required by WAC $173-400-040(1)$.

If the existing sources are not altered or modified, registration requirements of WAC 173-400-100 will not apply. Under this code, NSPS are normally enforced.

The regulations in 40 CFR 70, promulgated as of December 4, 1992, provide for the establishment of comprehensive state air quality permitting systems consistent with the requirement of Title $\mathrm{V}$ of the Clean Air Act. Although 40 CFR 70 does not implement any new control requirements, the Title $\mathrm{V}$ operating permit provides an administrative tool to list all regulatory requirements together. All sources subject to these regulations shall have an operating permit that ensures compliance with all applicable requirements. The governor of each state was required to submit a state program to the EPA administrator by November 15, 1993, showing how the State would meet the Part 708 permitting requirements. The state program, with whole or partial approval under the Part 70.3 , must provide permitting of any major source.

The 300 Area steam plant is considered a major source. However, most of the total plant emission is caused by the existing boilers systems. The existing coal- and oil-fired boilers have the potential to release sulfur dioxide in excess of 100 tons/year based on $2.4 \%$ sulfur in No. 6 fuel oil and $1.0 \%$ sulfur in coal. 
In response to the Federal Part 70 requirements, the State of Washington adopted the State Program in September 1993, and issued the revised WAC 173-400 on October 4, 1993. Under the State Program, the subject facility probably will be required to submit an application to the State in the first quarter of 1995 to obtain a source operating permit. The facility at that time probably would undergo a RACT review/assessment. As a result of the RACT review/assessment, the emission of $\mathrm{SO}_{2}$ would have to be limited for the facility to meet the State permitting requirements. The RACT considerations would indulge $\mathrm{SO}_{2}$ emission reduction by reducing operational hours or changing high sulfur coal and oil to low sulfur coal and oil or switch to natural gas. If an economic evaluation determined that changing to low sulfur fuel is relatively expensive, the State would allow the facility to consider a scrubbed application. Thus, RACT would be considered on a case-by-case basis using a top down approach.

It is reasonable to assume that the existing boiler system would be required to reduce the $\mathrm{SO}_{2}$ emissions through the above RACT review process by 1995 to 1996.

A stationary source that emits or has the potential to emit 100 tons/year or more of any of the priority pollutants (e.g., particulates, $\mathrm{NO}_{\mathrm{x}}, \mathrm{SO}_{2}$ ) is considered a major source. A new regulation proposed by EPA would require a continuous monitoring system for all sources that contribute up to $30 \%$ of a major source emission. The revised State regulation WAC 173-401 includes a provision for enhanced monitoring and reference to section 504(b) of the Federal Clean Air Act. Thus, the existing boilers stack which has the potential to emit more than 30 tons/yr of $\mathrm{NO}_{\mathrm{x}}, \mathrm{SO}_{2}, \mathrm{CO}$, and $\mathrm{PM}_{10}$ combined will have to be equipped with a continuous monitoring system."

\section{Environmental Requirements for the Steam Plant if Modified to Use Natural Gas}

"The oil-fired boilers are converted to dual fuel (oil or natural gas) firing. This conversion would be considered a major modification. The owner would be required by WAC 173-400-100(d) to notify Ecology prior to the boiler modification work. Ecology would determine if a notice of construction is necessary. According to Section (3)(b)(iv) of the same code, if the proposed change is a major modification, the owner or operator shall demonstrate that all major sources owned or operated by such person in the state which are subject to emission limitation are in compliance or on a schedule for compliance with applicable emission limitations and standards under the Federal Clean Air Act.

The proposed modification will require a total heat input of $160 \mathrm{MBtu} / \mathrm{hr}$ which is approximately $80 \mathrm{MBtu}$ for each boiler based on a maximum steam demand of $120,000 \mathrm{lb} / \mathrm{hr}$. Subpart Dc of 40 CFR 60 would also be applicable to this modification. The affected facility to which this Subpart applies is each steam generating unit for which construction, modification, or reconstruction is commenced after June 9, 1989 and that has a maximum design heat input capacity of $100 \mathrm{MBtu} / \mathrm{hr}$ or 
less, but greater than $10 \mathrm{MBtu} / \mathrm{hr}$. This regulation limits the emission of $\mathrm{SO}_{2}$ to $0.5 \mathrm{lb} / \mathrm{MBtu}$ heat input for an oil-fired boiler. For normal operation when the boiler is fired with natural gas, the requirements of 40 CFR 60 do not apply.

Based on $2.4 \%$ sulfur in No. 6 Bunker $\mathrm{C}$ fuel oil, the expected $\mathrm{SO}_{2}$ emission for the oil-firing mode has been estimated at $2.7 \mathrm{lb} / \mathrm{MBtu}$ heat input. Therefore, if the fuel oil-firing capability is viewed by the agency as a potential emission source, this modification may require changing to low sulfur fuel oil or installing a scrubber to limit the $\mathrm{SO}_{2}$ emission.

However, it would be possible to negotiate with the enforcing agency during the time of notification to allow boiler operation on fuel oil when the natural gas is cut off for a maximum 30-day period in any year. If a negotiation is reached with the agency, the proposed modification may be allowed to be implemented without changing to low sulfur fuel oil or installing a scrubber.

As noted above, the existing steam plant will probably be required to submit an application for a source operating permit in the first quarter of 1995. The RACT review/assessment will determine that $\mathrm{SO}_{2}$ emissions will have to be limited by using low sulfur coal and oil or $\mathrm{SO}_{2}$ scrubbers will have to be installed. In addition, continuous stack monitoring equipment will also have to be installed." 
Appendix B

LCCA Assumptions 


\section{Appendix B}

\section{LCCA Assumptions}

\section{Assumptions for Cash Flow and Life-Cycle Analysis}

Follow 10 CFR 436 life-cycle cost analysis methodology and use the National Institute of Standards and Technology (NIST) Building Life-Cycle Cost (BLCC) program, Version 4.2, to conduct the analysis.

Use constant dollars, i.e., do not include inflation.

Use current real discount rate of 3\%/yr for Federal Energy Management Program (FEMP) project (energy related).

Use interest rate of $12 \% / y r$ for cost of capital by Energy Saving Performance Contractor (ESPC). This interest rate includes $\approx 3.9 \%$ for inflation. Therefore, adjusted for inflation, the constant dollar interest rate to be used in the LCCA is $8.1 \%$ (12-3.9\%).

Allow three years to transition to the new distributed heating system. This period allows for contracting with an ESPC, having them perform a detailed engineering design of the new heating system, selecting acceptable alternatives, installing a natural gas pipeline into the 300 Area, and constructing and commissioning the new heating system. Assume the ESPC contractor borrows the entire project cost for one year before getting any payments.

Run two repayment scenarios: a 3-year amortization schedule for paying the ESPC contractor for the capital investment in the new distributed heating system and a 10-year amortization schedule.

Assume fuel prices will change according to NIST (1994a).

Assume all major buildings will remain active and heated. PNL has $756,874 \mathrm{ft}^{2}$ of steam-heated space to be converted and W-HC/ICF-KH has $263,777 \mathrm{ft}^{2}$ of steam-heated space to be converted.

Run two study periods: a 13-year study period, 1995 to 2008, (allows 3 years for transition and 10 years of operation of the new system) and the other would be a 28 -year study period, 1995 to 1023 (allows 3 years for transition and 25 years of operation of the new system per 10 CFR 436 requirements). 
Assume no major mission changes, i.e., building heating needs stay roughly the same.

Inputs into the BLCC program, in some cases are limited in size or amount, thus necessitating multiple inputs.

\section{Assumptions for Existing Steam System}

Assume the following capital upgrades are installed to keep the existing system operational (costs through 2007 are for the 13-year study):

\begin{tabular}{|c|c|c|c|}
\hline $\begin{array}{l}\text { FY } \\
\text { Funds }\end{array}$ & $\begin{array}{c}\text { Cost } \\
\text { (\$ millions) }\end{array}$ & Project Description & Status \\
\hline 1997 & 1.0 & 384 Bldg. fire sprinkler/NFPA upgrades ${ }^{(\mathrm{a})}$ & scheduled \\
\hline 1997 & 3.0 & 300 Area steam condensate line upgrades ${ }^{(a)}$ & scheduled? \\
\hline 1998 & 15.0 & $\mathrm{SO}_{2}$ stack scrubbers for steam plant $t^{(b)}$ & projected \\
\hline 1999 & 12.9 & Steam condensate line upgrades and expansion ${ }^{(\mathrm{c})}$ & projected \\
\hline 2002 & 1.1 & 300 Area steam plant improvements ${ }^{(a)}$ & projected \\
\hline 2004 & 20.5 & Replacement of $25 \%$ of the steam supply piping ${ }^{(d)}$ & projected \\
\hline 2006 & 1.1 & 300 Area steam plant improvements ${ }^{(a)}$ & projected \\
\hline 2010 & 1.1 & 300 Area steam plant improvements ${ }^{(a)}$ & projected \\
\hline 2014 & 1.1 & 300 Area steam plant improvements ${ }^{(a)}$ & projected \\
\hline 2018 & 1.1 & 300 Area steam plant improvements ${ }^{(2)}$ & projected \\
\hline 2022 & 1.1 & 300 Area steam plant improvements ${ }^{(a)}$ & projected \\
\hline
\end{tabular}

(a) Internal Memo from K. D. Hayden to C. M. Lewis regarding 384 Power House Future Planned Capital Projects dated October 26, 1992. These projected capital projects were used in ICF-KKH (1993).

(b) Need for stack scrubbers is referenced in ICF-KH (1994) to comply with Clean Air Act and other environmental regulations. Cost is rough order of magnimde, estimated by ICF-KH and supplied by Rob Piippo.

(c) Cost of $\$ 12.9$ million cited from ICF-KH (1993). It is assumed that this cost is in addition to the $\$ 3$ million already planned to be spent in FY97 according to the Hayden-Lewis internal memo (see foomote [a]). These condensate system upgrades will eliminate discharges of condensate to french drains or sewer systems per current environmental requirements.

(d) Cost of $\$ 20.5$ million to replace the aboveground piping in the 300 Area was cited in ICF-KH (1993). This activity would replace about $25 \%$ of the total 300 Area steam supply piping. Given the system's present age of approximately 40 years, it is unlikely that the system can avoid some partial replacement within the next 28 -year operating period.

In addition, assume $\$ 200,000$ of Capital Equipment NoT Related to Construction (CENTRC) money will be authorized yearly (see Hayden memo referenced above) for the 300 Area steam plant. This amount was input into the BLCC program as an O\&M cost. 
Assume that the residual book value of the stack scrubbers is $60 \%$ at the end of the 13 -year study period, the condensate line upgrade is $60 \%$, the steam supply piping is $75 \%$ of the initial capital cost, and the values are calculated as follows:

$$
\begin{array}{ll}
60 \% \text { of } \$ 15.0 \text { million (stack scrubbers) } & =\$ 9.00 \text { million } \\
60 \% \text { of } \$ 12.9 \text { million (condensate line upgrade) } & =\$ 7.74 \text { million } \\
75 \% \text { of } \$ 20.5 \text { million (steam supply piping) } & =\frac{\$ 15.38 \text { million }}{} \\
& \$ 32.12 \text { million }
\end{array}
$$

Because of the age of the existing boilers and the steam distribution system, assume that the residual book value at the end of the 28 -year study period is $0 \%$ of all capital investments.

The WHC FY95 fiscal year work plan for the 300 Area steam plant and meetings with ICF-KH-Utilities indicate the current annual operating costs as follows:

Labor

Other (includes indirect labor, overheads, and $15.9 \%$ G\&A)

Subtotal for O\&M (excluding fuel)

Material (i.e., Fuel)

Total
$\$ 3.87$ million

$\$ 4.44$ million

$\$ 8.31$ million

$\$ 1.28$ million

$\$ 9.59$ million

Previous meetings regarding the 300 Area steam plant operating costs (excluding compressed air) for FY93 indicated that the electrical costs (BPA cost only) were about $\$ 175,000 / y r$. Since BPA prices have risen $15.7 \%$ since then, the present annual cost for electricity should be about $\$ 202,500 / y r$. Based on the BPA electrical cost, the steam plant electrical consumption is about $7,777,778 \mathrm{kWh} / \mathrm{yr}$. The cost for \#6 residual fuel oil ( 2.5 million gals/yr according to ICF-KH [1993]) is then $\$ 1,280,000-\$ 202,500=\$ 1,077,500 / y \mathrm{y}$. Coal will no longer be burned in the steam plant because the application for a wastewater discharge permit from the State of Washington for the ash disposal pit has been denied.

\section{Assumptions for New Heating System Operated by Private Contractor}

Assume that a life-cycle cost-effective heating system is located at the building where the heat or steam is needed. It consists of a mix of electric heat, heat pumps, gas-fired duct heaters, gas furnaces, gas-fired hot water boilers, and gas-fired steam boilers with propane backup for gas. 
Assume that the total design and construction cost of converting to the new distributed heating system is $\$ 10,340,000$ and takes 3 years, during which the existing steam system continues to operate. This cost is based on a cost estimate of about $\$ 7,670,000$ in the Johnson Controls, Inc., study of the 300 Area (for PNL facilities except as modified by Rev. 1) (JCI 1994). This cost estimate, which averages $\$ 10.13 / \mathrm{ft}^{2}$ of PNL building space, is then prorated over an additional $263,772 \mathrm{ft}^{2}$ of WHC building space to arrive at an additional cost of $\$ 2,670,000$, thus totaling $\$ 10,340,000$.

The cost to DOE of extending the Cascade Natural Gas Inc. pipeline into the 300 Area (including distribution piping and metering) is $\$ 2,500,000$ according to Cascade Natural Gas Inc. (confirmed in a meeting with the local Cascade manager).

Therefore the total capital cost for the new system in the 300 Area is $\$ 10,340,000+\$ 2,500,000$ $=\$ 12,840,000$.

Assume that the cost of obtaining and administering an ESPC is included in the $20 \%$ contingency cost.

Thus the cost to invest in the new 300 Area heating system:

New distributed heating system

New natural gas pipeline and distribution system

Subtotal of total capital costs

Contingency costs $(20 \%)$

Total project cost
$\$ 10,340,000$

$\$ 2,500,000$

$\$ 12,840,000$

$\$ 2,568,000$

$\$ 15,408,000$

The future value of $\$ 15,408,000$ borrowed for one year at $8.1 \%$ is $\$ 16,656,048$. This money, paid to the ESPC contractor over the next 3 years under the first scenario or 10 years under the second scenario (once the new distributed system is working and the existing steam plant has been shut down), is still costing $8.1 \%$, compounded annually on the unpaid principal. Thus, the annual payment to the ESPC contractor equals $\$ 6,474,770$ for the 3 -year repayment scenario or $\$ 2,493,450$ for the 10-year repayment scenario. This was determined using the DISCOUNT program provided with the BLCC program (NIST 1994b).

Assume the new heating system has a useful life of 30 years and the residual book value of the new system at the end of the study period is equal to the prorated remaining years. Therefore the residual value will be 
13-Year Study

28-Year Study $\frac{20 \text { years remaining life }}{30 \text { years total life }} \times \$ 12,840,000=\$ 8,560,000$

or

$\frac{5 \text { years remaining life }}{30 \text { years total life }} \times \$ 12,840,000=\$ 2,140,000$

The resale (i.e., residual) value factor was empirically derived and input into the BLCC program to obtain a result close to the residual book values above. For the 13-year study with the 3-year loan repayment schedule the factor is $44.1 \%$, and for the 13-year study with the 10-year loan repayment schedule, the factor is $34.3 \%$. For the 28-year study with the 3-year loan repayment schedule, the factor is $11.0 \%$, and for the 28 -year study with the 10 -year loan repayment schedule, the factor is $8.6 \%$.

Assume O\&M costs for the new system are based on standard industrial requirements. JCI has estimated that maintenance labor for the new distributed boiler system will require four full-time equivalent private contractor employees (this estimate includes the boilers for WHC buildings) at a cost of $\$ 502,000$ for maintenance ( $8032 \mathrm{hrs} X \$ 62.50 / \mathrm{hr}$ ). Materials and services (chemical, operational monitoring, boiler tuneups, etc.) will require another $\$ 300,000$. Thus, the total new annual O\&M cost is estimated to be $\$ 802,000$.

JCI estimated the fuel cost for a distributed steam boiler system in the PNL-managed buildings to be $\$ 791,393 / \mathrm{yr}$ for natural gas and $\$ 47,476$ for electricity. Prorating the JCI estimate over PNL's $756,874 \mathrm{ft}^{2}$ of converted facility area and applying it to an additional $263,772 \mathrm{ft}^{2}$ of WHC facility space increases JCl's original annual estimate by $\$ 275,802$ for natural gas and $\$ 16,545$ for electricity. Totals for the 300 Area would be $\$ 1,067,195$ for natural gas and $\$ 64,021$ for electricity. The cost of electricity used in the JCI study was $\$ 0.065 / \mathrm{kWh}(\$ 0.026 / \mathrm{kWh}$ BPA electricity cost $+\$ 0.039 / \mathrm{kWh}$ ICF-KH-Utilities transmission and distribution cost) and for natural gas was $\$ 0.42 /$ therm (current cost of natural gas from Cascade Natural Gas). Therefore, the new annual 300 Area fuel consumption can be calculated to be $2,540,940$ therms of natural gas $(\$ 1,067,195$ divided by $\$ 0.42 /$ therm) and $984,938 \mathrm{kWh}$ of electricity $(\$ 64,021$ divided by $\$ 0.065 / \mathrm{kWh})$. Electricity use of $984,938 \mathrm{kWh}$ times the BPA cost of $\$ 0.026 / \mathrm{kWh}$ gives a total cost for electricity of $\$ 25,608$. Therefore, the new total annual fuel cost is $\$ 25,608+\$ 1,067,195=\$ 1,092,803$. 


\section{Appendix C}

\section{Life-Cycle Cost Analysis for Exisiting Central Steam Plant, 13-Year Study Period}


* N I S T B L C C

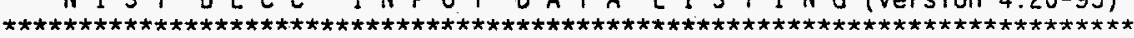

FILE NAME: STMPLT1

FILE LAST MODIFIED ON 01-21-1995/15:57:13

PROJECT ALTERNATIVE: STMPLT

COMMENT: Existing 300 Area Central Steam Plant, 13 Yr Stdy

GENERAL DATA:

ANALYSIS TYPE: Federal Analysis--Energy Conservation Projects

BASE DATE FOR LCC ANALYSIS: JAN 1995

STUDY PERIOD: 13 YEARS, O MONTHS

SERVICE DATE: JAN 1995

DISCOUNT AND INTEREST RATES ARE Real (exclusive of general inflation)

DISCOUNT RATE: $3.0 \%$

Escalation rates do not include general inflation

CAPITAL ASSET COST DATA:

NUMBER OF CAPITAL COMPONENTS: 3

COMPONENT NAME:

INITIAL COST (BASE YEAR \$)

EXPECTED ASSET LIFE (YRS/MTHS)

RESALE VALUE FACTOR

NUMBER OF REPLACEMENTS

Boiler House
0
$0 / 0$
$0.00 \%$
3

Piping
0
$0 / 0$
$0.00 \%$
6

General

REPLACEMENTS TO CAPITAL ASSETS:

REPLACEMENTS TO Boiler House:

REPLACEMENT NUMBER

YEARS/MONTHS FROM SERVICE DATE

INITIAL COST (BASE YEAR \$)

EXPECTED REPL. LIFE (YRS/MTHS)

RESALE VALUE FACTOR

1
$3 / 0$
$\$ 1,000,000$
$30 / 0$
$0.00 \%$

2
$4 / 0$
$\$ 9.999 .999$
$30 / 0$
$60.00 \%$

3
$4 / 0$
$\$ 5,000,001$
$30 / 0$
$60.00 \%$

REPLACEMENTS TO Piping:

REPLACEMENT NUMBER

YEARS/MONTHS FROM SERVICE DATE

INITIAL COST (BASE YEAR \$)

EXPECTED REPL. LIFE (YRS/MTHS)

RESALE VALUE FACTOR

1
$3 / 0$
$\$ 3,000,000$
$30 / 0$
$0.00 \%$

2
$5 / 0$
$\$ 9.999 .999$
$30 / 0$
$60.00 \%$

3
$5 / 0$
$\$ 2,900,001$
$30 / 0$
$60.00 \%$

4
$10 / 0$
$\$ 9,999,999$
$20 / 0$
$75.00 \%$

REPLACEMENTS TO Piping:

REPLACEMENT NUMBER

YEARS/MONTHS FROM SERVICE DATE

INITIAL COST (BASE YEAR \$)

EXPECTED REPL. LIFE (YRS/MTHS)

RESALE VALUE FACTOR

$\begin{array}{cc}5 & 6 \\ 10 / 0 & 10 / 0 \\ \$ 9.999,999 & \$ 500,002 \\ 20 / 0 & 20 / 0 \\ 75.00 \% & 75.00 \%\end{array}$

REPLACEMENTS TO General:

REPLACEMENT NUMBER

YEARS/MONTHS FROM SERVICE DATE

INITIAL COST (BASE YEAR \$)

EXPECTED REPL. LIFE (YRS/MTHS)

RESALE VALUE FACTOR

$\begin{array}{cc}1 & 2 \\ 8 / 0 & 12 / 0 \\ \$ 1,100,000 & \$ 1,100,000 \\ 30 / 0 & 30 / 0 \\ 0.00 \% & 0.00 \%\end{array}$


OPERATING, MAINTENANCE. AND REPAIR COST DATA BY COMPONENT:

\begin{tabular}{|c|c|c|c|}
\hline ANNUAL RECUR OM\&R COST (\$): & $\begin{array}{c}\text { COMP } 1 \\
\$ 8,310,000\end{array}$ & $\begin{array}{c}\text { COMP } 2 \\
\$ 0\end{array}$ & $\begin{array}{c}\text { COMP } 3 \\
\$ 200,000\end{array}$ \\
\hline
\end{tabular}

No non-annually-recurring OM\&R costs reported.

ENERGY-RELATED DATA:

NUMBER OF ENERGY TYPES $=2$

DOE energy price escalation rates filename: ENCOST95

DOE region (state code): 4 (WA)

DOE rate schedule type: Industrial

Underlying gen. inflation rate used with DOE rates: $0.00 \%$

ENERGY TYPE:

BASE ANNUAL CONSUMPTION:

UNITS:

PRICE PER UNIT (\$):

ANNUAL DEMAND CHARGE (\$):

ESCALATION RATE METHOO:

TYPE 1

TYPE 2

Residual 0il Electricity

$2.500 .000 \quad 7,777,778$

Gallon KWh

$0.410 \quad 0.026$

$0.00 \quad 0.00$

DOE rates DOE rates

$\begin{array}{llr}1995 & 5.12 & 0.43 \\ 1996 & 3.01 & -0.23 \\ 1997 & 3.50 & -0.56 \\ 1998 & 3.82 & -0.26 \\ 1999 & 3.67 & 0.56 \\ 2000 & 4.45 & 0.96 \\ 2001 & 4.54 & 0.49 \\ 2002 & 3.85 & -0.07 \\ 2003 & 3.93 & 0.07 \\ 2004 & 3.46 & -0.13 \\ 2005 & 2.05 & -0.49 \\ 2006 & 2.10 & -0.33 \\ 2007 & 2.89 & 0.33 \\ 2008 & 1.92 & 0.59\end{array}$

C. 2 
* N IST B L C C - D ET A I L E D LC C A N A Y Y S I S (version $4.20-95) *$

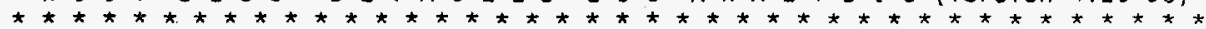

PART 1 - INITIAL ASSUMPTIONS AND COST DATA

Project alternative: STMPLT

Run date: 01-21-1995 15:57:57

Run type: Federal Analysis--Energy Conservation Projects

Comment: Existing 300 Area Central Steam Plant. $13 \mathrm{Yr}$ Stdy

Input data file: STMPLT1.DAT, last modified: 01-21-1995/15:57:13

LCC output file: STMPLT1.LCC, created: 01-21-1995/15:57:18

Base Date of Study: JAN 1995

Service Date: JAN 1995

Study period: $\quad 13.00$ years (JAN 1995 through DEC 2007)

Discount rate: $\quad 3.0 \%$ Real (exclusive of general inflation)

End-of-year discounting convention

Note: This BLCC report satisfies the economic evaluation criteria of FEMP requirements for federal energy studies.

INITIAL CAPITAL ASSET COSTS (NOT DISCOUNTEO)

TOTAL FOR Boiler House

Total Cost

TOTAL. FOR Piping

TOTAL FOR Genera]

TOTAL INITIAL CAPITAL ASSET COSTS

\begin{tabular}{|c|c|c|c|c|c|c|}
\hline \multicolumn{7}{|c|}{ ENERGY-RELATED COSTS } \\
\hline $\begin{array}{l}\text { Energy } \\
\text { Type }\end{array}$ & Units & $\begin{array}{l}\text { Units/ } \\
\text { Year }\end{array}$ & $\begin{array}{l}\text { Pricet } \\
\text { (\$/Unit) }\end{array}$ & $\begin{array}{l}\text { Energy } \\
\text { Ennual }\end{array}$ & $\begin{array}{c}\text { Cost } \\
\text { Demand }\end{array}$ & $\begin{array}{l}\text { Total } \\
\text { P.V. Cost }\end{array}$ \\
\hline$----n-m-n$ & $-----\infty$ & & $-\cdots+-\infty$ & $---n---n$ & $-----m--$ & -------- \\
\hline $\begin{array}{l}\text { Reșidual oil } \\
\text { Electricity }\end{array}$ & $\begin{array}{l}\text { Gallon } \\
\mathrm{kWh}\end{array}$ & $\begin{array}{l}2,500,000 \\
7,777,778\end{array}$ & $\begin{array}{l}\$ 0.410 \\
\$ 0.026\end{array}$ & $\begin{array}{r}\$ 1,025,000 \\
\$ 202,222\end{array}$ & $\begin{array}{l}\$ 0 \\
\$ 0\end{array}$ & $\begin{array}{r}\$ 14.107 .290 \\
\$ 2.162 .631\end{array}$ \\
\hline
\end{tabular}

+Price and annual cost are as of base date (not adjusted for price escalation)

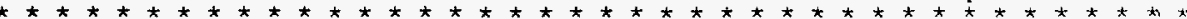


PART II - LIFE-CYCLE COST ANALYSIS

Discount Rate $=3.0 \%$ Real (exclusive of general inflation)

\begin{tabular}{|c|c|c|}
\hline \multirow[t]{2}{*}{ PROJECT ALTERNATIVE: STMPLT } & \multicolumn{2}{|c|}{ RUN DATE: $01-21-1995 / 15: 57: 57$} \\
\hline & $\begin{array}{l}\text { PRESENT VALUE } \\
(1995 \text { DOLLARS })\end{array}$ & $\begin{array}{l}\text { ANNUAL VALUE } \\
\text { (1995 DOLLARS) }\end{array}$ \\
\hline CASH REQUIREMENTS AS OF SERVICE DATE & $\$ 0$ & $\$ 0$ \\
\hline $\begin{array}{l}\text { OPERATING, MAINTENANCE \& REPAIR COSTS: } \\
\text { BOi ler HOUSE: } \\
\text { ANNUALLY RECURRING COSTS (NON-ENERGY) }\end{array}$ & $\$ 88.376 .416$ & $\$ 8.310 .000$ \\
\hline $\begin{array}{l}\text { Piping: } \\
\text { ANNUALLY RECURRING COSTS (NON-ENERGY) }\end{array}$ & $\$ 0$ & $\$ 0$ \\
\hline $\begin{array}{l}\text { General: } \\
\text { ANNUALLY RECURRING COSTS (NON-ENERGY) }\end{array}$ & $\$ 2,126.990$ & $\$ 200.000$ \\
\hline SUBTOTAL & $\$ 90,503,408$ & $\$ 8.510,000$ \\
\hline ENERGY COSTS & $\$ 16.269 .920$ & $\$ 1.529 .854$ \\
\hline $\begin{array}{l}\text { REPLACEMENTS TO CAPITAL COMPONENTS } \\
\text { Boiler House } \\
\text { Piping } \\
\text { General }\end{array}$ & $\begin{array}{r}\$ 14,242,450 \\
\$ 29,127,010 \\
\$ 1,639,869\end{array}$ & $\begin{array}{r}\$ 1,339.212 \\
\$ 2.738 .802 \\
\$ 154.196\end{array}$ \\
\hline SUBTOTAL & $\$ 45,009,328$ & $\$ 4,232,210$ \\
\hline $\begin{array}{l}\text { RESALE VALUE OF ORIG CAPITAL COMPONENTS } \\
\text { Boiler House } \\
\text { Piping } \\
\text { General }\end{array}$ & $\begin{array}{l}\$ 0 \\
\$ 0 \\
\$ 0\end{array}$ & $\begin{array}{l}\$ 0 \\
\$ 0 \\
\$ 0\end{array}$ \\
\hline SUBTOTAL & $\$ 0$ & $\$ 0$ \\
\hline $\begin{array}{l}\text { RESALE VALUE OF CAPITAL REPLACEMENTS } \\
\text { Boiler House } \\
\text { Piping } \\
\text { General }\end{array}$ & $\begin{array}{r}\$ 6,128,565 \\
\$ 15,740.200 \\
\$ 0\end{array}$ & $\begin{array}{r}\$ 576.267 \\
\$ 1.480 .045 \\
\$ 0\end{array}$ \\
\hline SUBTOTAL & $\$ 21,868,760$ & $\$ 2,056,311$ \\
\hline TOTAL LIFE-CYCLE PROJECT COST & $\$ 129,913,896$ & $\$ 12,215,753$ \\
\hline
\end{tabular}

C. 4 
PART III - EMISSIONS SUMMARY Ia

\begin{tabular}{|c|c|c|}
\hline $\begin{array}{l}\text { Energy } \\
\text { Type }\end{array}$ & $\begin{array}{c}\text { Annual } \\
\text { Emissions }\end{array}$ & $\begin{array}{l}\text { Life-cycle } \\
\text { Emissions }\end{array}$ \\
\hline \multicolumn{3}{|c|}{ Residual 0il: } \\
\hline $\mathrm{CO2}(\mathrm{Kg}):$ & $28,656,800.0$ & $372,538,000$ \\
\hline SOx $(\mathrm{Kg}):$ & 145.687 .7 & ??? \\
\hline NOX $(\mathrm{Kg}):$ & $61,917,3$ & 804.924 \\
\hline \multicolumn{3}{|c|}{ Electricity: } \\
\hline $\operatorname{co2}(\mathrm{Kg}):$ & $4,518,013.0$ & $58,734,168$ \\
\hline sox $(\mathrm{Kg}):$ & 37.959 .8 & 290,393 \\
\hline NOX $(\mathrm{Kg}):$ & $19,378.1$ & 251,915 \\
\hline \multicolumn{3}{|l|}{ Total: } \\
\hline $\mathrm{CO} 2(\mathrm{Kg}):$ & $33,174,800.0$ & $431,272,000$ \\
\hline SOx $(\mathrm{Kg}):$ & $183,647.5$ & ??? \\
\hline NOX $(\mathrm{Kg})$ : & 81.295 .3 & $1,056,839$ \\
\hline
\end{tabular}

la Based on emission factors from file EMISSION. FIL 


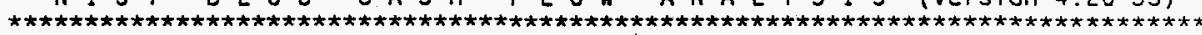

PROJECT ALTERNATIVE: STMPLT

COMMENT: Existing 300 Area Central Steam Plant. $13 \mathrm{Yr}$ Stdy

RUN DATE: 01-21-1995 15:58:11

INPUT DATA FILE: STMPLT1.DAT, LAST MODIFIED 01-21-1995/15:57:13

STUDY PERIOD: $\quad 13.00$ YEARS (JAN 1995 THROUGH DEC 2007)

ANALYSIS TYPE: Federal Analysis--Energy Conservation Projects

All costs in constant 1995 dollars (i.e.. excluding general infiation)

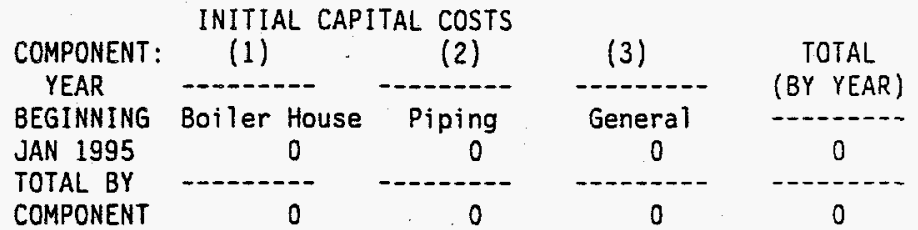

CAPITAL INVESTMENT COSTS

\begin{tabular}{|c|c|c|c|c|}
\hline $\begin{array}{c}\text { YEAR } \\
\text { BEGINNING }\end{array}$ & $\begin{array}{l}\text { INIT CAPITAL } \\
\text { INVESTMENT }\end{array}$ & $\begin{array}{l}\text { CAPITAL } \\
\text { REPLACEMENTS }\end{array}$ & $\begin{array}{l}\text { CAPITAL } \\
\text { DISPOSAL }\end{array}$ & $\begin{array}{l}\text { TOTAL CAP. } \\
\text { INVESTMENT }\end{array}$ \\
\hline - - & - & ------- & & $\ldots$ \\
\hline JAN 1995 & 0 & 0 & 0 & 0 \\
\hline JAN 1996 & ' & 0 & 0 & 0 \\
\hline JAN 1997 & 0 & $4,000,000$ & 0 & $4,000,000$ \\
\hline AN 1998 & 0 & $15,000,000$ & 0 & 15.000 .000 \\
\hline JAN 1999 & 0 & $12,900,000$ & 0 & $12,900,000$ \\
\hline JAN 2000 & 0 & 0 & 0 & 0 \\
\hline JAN 2001 & 0 & 0 & 0 & 0 \\
\hline JAN 2002 & 0 & $1,100,000$ & 0 & $1,100,000$ \\
\hline JAN 2003 & 0 & 0 & 0 & 0 \\
\hline JAN 2004 & 0 & 20.500 .000 & 0 & 20.500 .000 \\
\hline JAN 2005 & 0 & 0 & 0 & 0 \\
\hline JAN 2006 & 0 & $1.100,000$ & 0 & 1.100 .000 \\
\hline JAN 2007 & 0 & 0 & $32,115,002$ & $-32,115,002$ \\
\hline TOTAL & 0 & 54.600 .000 & $32,115,002$ & 22.484 .998 \\
\hline
\end{tabular}

OPERATING-RELATED COSTS DURING SERVICE PERIOD:

\begin{tabular}{|c|c|c|c|c|c|}
\hline $\begin{array}{l}\text { YEAR } \\
\text { BEGINNING }\end{array}$ & ANNUAL & $\begin{array}{l}\text { OPERATING-REL } \\
\text { NON-ANNUAL }\end{array}$ & $\begin{array}{c}\text { ATED COSTS } \\
\text { ENERGY }\end{array}$ & WATER & $\begin{array}{l}\text { TOTAL } \\
\text { OPER. COST }\end{array}$ \\
\hline & & & 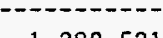 & & $0700-50$ \\
\hline JAN 1995 & $8,510,000$ & 0 & $1.280,521$ & 0 & $9,790,521$ \\
\hline JAN 1996 & $8,510,000$ & 0 & $1,312,514$ & 0 & 9.822 .514 \\
\hline JAN 1997 & $8,510,000$ & 0 & $1,350,221$ & 0 & 9.860 .221 \\
\hline JAN 1998 & 8.510 .000 & 0 & $1,393,543$ & 0 & 9.903 .543 \\
\hline JAN 1999 & $8,510,000$ & 0 & $1,438,469$ & 0 & $9,948,469$ \\
\hline JAN 2000 & $8,510,000$ & 0 & $1,495,378$ & 0 & 10.005 .378 \\
\hline JAN 2001 & $8,510,000$ & 0 & $1,554,961$ & 0 & $10,064.961$ \\
\hline JAN 2002 & 8.510 .000 & 0 & $1,606.767$ & 0 & 10.116 .767 \\
\hline JAN 2003 & 0.000 & 0 & 1.662 .024 & 0 & $10,172,024$ \\
\hline JAN 2004 & 8.510 .000 & 0 & 1.712 .209 & 0 & 10.222 .209 \\
\hline JAN 2005 & .000 & 0 & $1,742,159$ & 0 & 10.252 .159 \\
\hline JAN 2006 & .000 & 0 & $1.773,816$ & 0 & 10.283 .816 \\
\hline JAN 2007 & & 0 & 1.819 .925 & 0 & $10,329,924$ \\
\hline TOTAL & 110.630 .000 & 0 & $20,142,508$ & 0 & 130.772 .508 \\
\hline
\end{tabular}




\begin{tabular}{|c|c|c|c|}
\hline $\begin{array}{c}\text { YEAR } \\
\text { BEGINNING }\end{array}$ & $\begin{array}{l}\text { CAPITAL } \\
\text { INVESTMENT }\end{array}$ & $\begin{array}{l}\text { OPERATING } \\
\text { COSTS }\end{array}$ & $\begin{array}{r}\text { TOTAL } \\
\text { COST }\end{array}$ \\
\hline$----\ldots-n$ & & $\cdots$ & \\
\hline JAN 1995 & $\$$ & $\$ 9,790,521$ & $\$ 9,790,521$ \\
\hline JAN 1996 & 0 & $9,822,514$ & 9.822 .514 \\
\hline JAN 1997 & $4,000,000$ & $9,860,221$ & $13,860,221$ \\
\hline JAN 1998 & $15,000,000$ & $9,903,543$ & $24,903,544$ \\
\hline JAN 1999 & $12,900,000$ & $9.948,469$ & $22,848,468$ \\
\hline JAN 2000 & 0 & $10,005,378$ & $10,005,378$ \\
\hline JAN 2001 & 0 & $10,064.961$ & 10.064 .961 \\
\hline JAN 2002 & $1,100,000$ & $10,116,767$ & $11,216,767$ \\
\hline JAN 2003 & 0 & $10,172,024$ & $10,172,024$ \\
\hline JAN 2004 & $20,500,000$ & $10,222,209$ & $30,722,208$ \\
\hline JAN 2005 & 0 & $10.252,159$ & $10,252,159$ \\
\hline JAN 2006 & $1,100,000$ & $10,283,816$ & $11,383,816$ \\
\hline JAN 2007 & $-32,115,002$ & $10,329,924$ & $-21,785,078$ \\
\hline TOTAL & $\$ 22,484,998$ & $\$ 130,772,508$ & $\$ 153,257,506$ \\
\hline
\end{tabular}

SUM OF ALL CASH FLOWS (w/o showing residual value)

\begin{tabular}{|c|c|c|c|}
\hline $\begin{array}{c}\text { YEAR } \\
\text { BEGINNING }\end{array}$ & $\begin{array}{l}\text { CAPITAL } \\
\text { INVESTMENT }\end{array}$ & $\begin{array}{c}\text { OPERATING } \\
\text { COSTS }\end{array}$ & $\begin{array}{l}\text { TOTAL } \\
\text { COST }\end{array}$ \\
\hline$-----\cdots$ & & $-\cdots-\cdots$ & ------ \\
\hline JAN 1995 & $\$$ & $\$ 9.790 .521$ & $\$ 9,790,521$ \\
\hline JAN 1996 & 0 & 9.822 .514 & 9.822 .514 \\
\hline JAN 1997 & $4,000,000$ & $9.860,221$ & $13,860,221$ \\
\hline JAN 1998 & $15,000,000$ & 9.903 .543 & $24,903,544$ \\
\hline JAN 1999 & $12,900,000$ & 9.948 .469 & $22,848,468$ \\
\hline JAN 2000 & 0 & $10,005,378$ & $10,005,378$ \\
\hline JAN 2001 & 0 & $10,064,961$ & $10,064,961$ \\
\hline JAN 2002 & $1,100,000$ & 10.116 .767 & 11.216 .767 \\
\hline JAN 2003 & 0 & 10.172 .024 & $10,172,024$ \\
\hline JAN 2004 & $20,500,000$ & $10,222,209$ & $30,722,208$ \\
\hline JAN 2005 & 0 & $10,252,159$ & 10.252 .159 \\
\hline JAN 2006 & 1.100 .000 & 10.283 .816 & $11.383,816$ \\
\hline JAN 2007 & 0 & $10,329,924$ & 10.329 .924 \\
\hline TOTAL & $\$ 54,600,000$ & $\$ 130,772.512$ & $\$ 185,372,512$ \\
\hline
\end{tabular}




\section{Appendix D}

Life-Cycle Cost Analysis for New Distributed Heating System, 13-Year Study Period and 3-Year Loan Repayment Period 


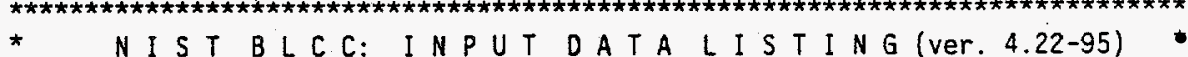

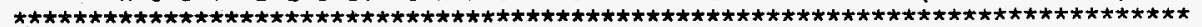

FILE NAME: NEWIA

FILE LAST MODIFIED ON 05-16-1995/17:40:00

PROJECT ALTERNATIVE: PVt. Newheat

COMMENT: 300A New Dist Heat Sys-ESPC prvt 0\&M 3yr payback

GENERAL DATA:

ANALYSIS TYPE: Federal Analysis--Energy Conservation Projects

BASE DATE FOR LCC ANALYSIS: JAN 1995

STUDY PERIOD: 13 YEARS, O MONTHS

SERVICE DATE: JAN 1995

DISCOUNT AND INTEREST RATES ARE Real (exclusive of general inflation)

DISCOUNT RATE: $3.0 \%$

Escalation rates do not include general inflation

CAPITAL ASSET COST DATA:

NUMBER OF CAPITAL COMPONENTS: 2

COMPONENT NAME:

INITIAL COST (BASE YEAR \$)

EXPECTED ASSET LIFE (YRS/MTHS)

RESALE VALUE FACTOR

NUMBER OF REPLACEMENTS

$\begin{array}{cc}\text { Existing Plt } & \text { New Heat Plt } \\ 0 & 0 \\ 3 / 0 & 0 / 0 \\ 0.00 \% & 0.00 \% \\ 0 & 3\end{array}$

REPLACEMENTS TO CAPITAL ASSETS:

REPLACEMENTS TO New Heat P1t:

REPLACEMENT NUMBER

YEARS/MONTHS FROM SERVICE DATE

INITIAL COST (BASE YEAR \$)

EXPECTED REPL. LIFE (YRS/MTHS)

RESALE VALUE FACTOR

$\begin{array}{ccc}1 & 2 & 3 \\ 3 / 6 & 4 / 6 & 5 / 6 \\ 6,474,770 & 6,474.770 & 6,474.770 \\ 30 / 0 & 29 / 0 & 28 / 0 \\ 44.10 \% & 44.10 \% & 44.10 \%\end{array}$

D. 1 
OPERATING, MAINTENANCE, AND REPAIR COST DATA BY COMPONENT:

COMP 1 COMP 2

ANNUAL RECUR OMBR COST (\$):

0 O 0

NON-AN RECURRING OM\&R COSTS (YRS/MTHS FROM SERVICE DATE; COST IN BASE YEAR \$): COMP 1 COMP 2

$\begin{array}{lccc}Y / M & \text { COST } & Y / M & \text { COST } \\ 0 / 1 & 892500 & 3 / 6 & 802000 \\ 0 / 2 & 692500 & 4 / 6 & 802000 \\ 0 / 3 & 692500 & 5 / 6 & 802000 \\ 0 / 4 & 692500 & 6 / 6 & 802000 \\ 0 / 5 & 692500 & 7 / 6 & 802000 \\ 0 / 6 & 692500 & 8 / 6 & 802000 \\ 0 / 7 & 692500 & 9 / 6 & 802000 \\ 0 / 8 & 692500 & 10 / 6 & 802000 \\ 0 / 9 & 692500 & 11 / 6 & 802000 \\ 0 / 10 & 692500 & 12 / 6 & 802000 \\ 0 / 11 & 692500 & & \end{array}$

$0 / 11692500$

$1 / 0692500$

$1 / 1892500$

$1 / 2 \quad 692500$

$1 / 3 \quad 692500$

$1 / 4 \quad 692500$

$1 / 5 \quad 692500$

$1 / 6 \quad 692500$

$1 / 7 \quad 692500$

$1 / 8 \quad 692500$

$1 / 9 \quad 692500$

$1 / 10692500$

$1 / 11692500$

$2 / 0 \quad 692500$

$2 / 1892500$

$2 / 2 \quad 692500$

$2 / 3 \quad 692500$

$2 / 4 \quad 692500$

$2 / 5 \quad 692500$

$2 / 6 \quad 692500$

$2 / 7 \quad 692500$

$2 / 8 \quad 692500$

$2 / 9 \quad 692500$

$2 / 10692500$

$2 / 11692500$

$3 / 0 \quad 692500$ 
ENERGY-RELATED DATA:

NUMBER OF ENERGY TYPES $=3$

DOE energy price escalation rates filename: ENCOST95

DOE region (state code): 4 (WA)

DOE rate schedule type: Industrial

Underlying gen. inflation rate used with DOE rates: $0.00 \%$

ENERGY TYPE :

BASE ANNUAL CONSUMPTION:

UNITS:

PRICE PER UNIT (\$):

ANNUAL DEMAND CHARGE (\$):

ESCALATION RATE METHOD:
(A)

Electricity

$7,777,778$

kWh

0.026

0.00

DOE rates

0.43

$-0.23$

$-0.56$

$-0.26$

0.56

0.96

0.49

$-0.07$

0.07

$-0.13$

$-0.49$

$-0.33$

0.33

0.59

(B)

Residual 0il Natural Gas

$2,500,000 \quad 2,540,940$.

Gallon

0.410

0.00

Therm

0.420

0.00

DOE rates

DOE rates

\subsection{2}

3.01

3.13

2.18

2.25

3.82

3.67

1.86

1.36

4.45

4.54

1.79

2.75

3.85

3.93

2.16

1.57

3.46

2.05

2.10

2.89

3.19

2.22

1.85

4.03

2007
2008

ENERGY TYPE:

ENERGY USE INDEXES BY YEAR:

1995
1996
1997
1998
1999
2000
2001
2002
2003
2004
2005
2006
2007

Electr

1.92

2.98

1996

1997

1998

1999

2001

2002

2003

2004

2005

2007

Residual 0il Natural Gas

100.00
100.00
100.00
12.66
12.66
12.66
12.66
12.66
12.66
12.66
12.66
12.66
12.66

100.00

100.00

100.00

0.00

0.00

0.00

0.00

0.00

0.00

0.00

0.00

0.00

0.00

0.00

0.00

0.00

100.00

100.00

100.00

100.00

100.00

100.00

100.00

100.00

100.00

100.00

D. 3 


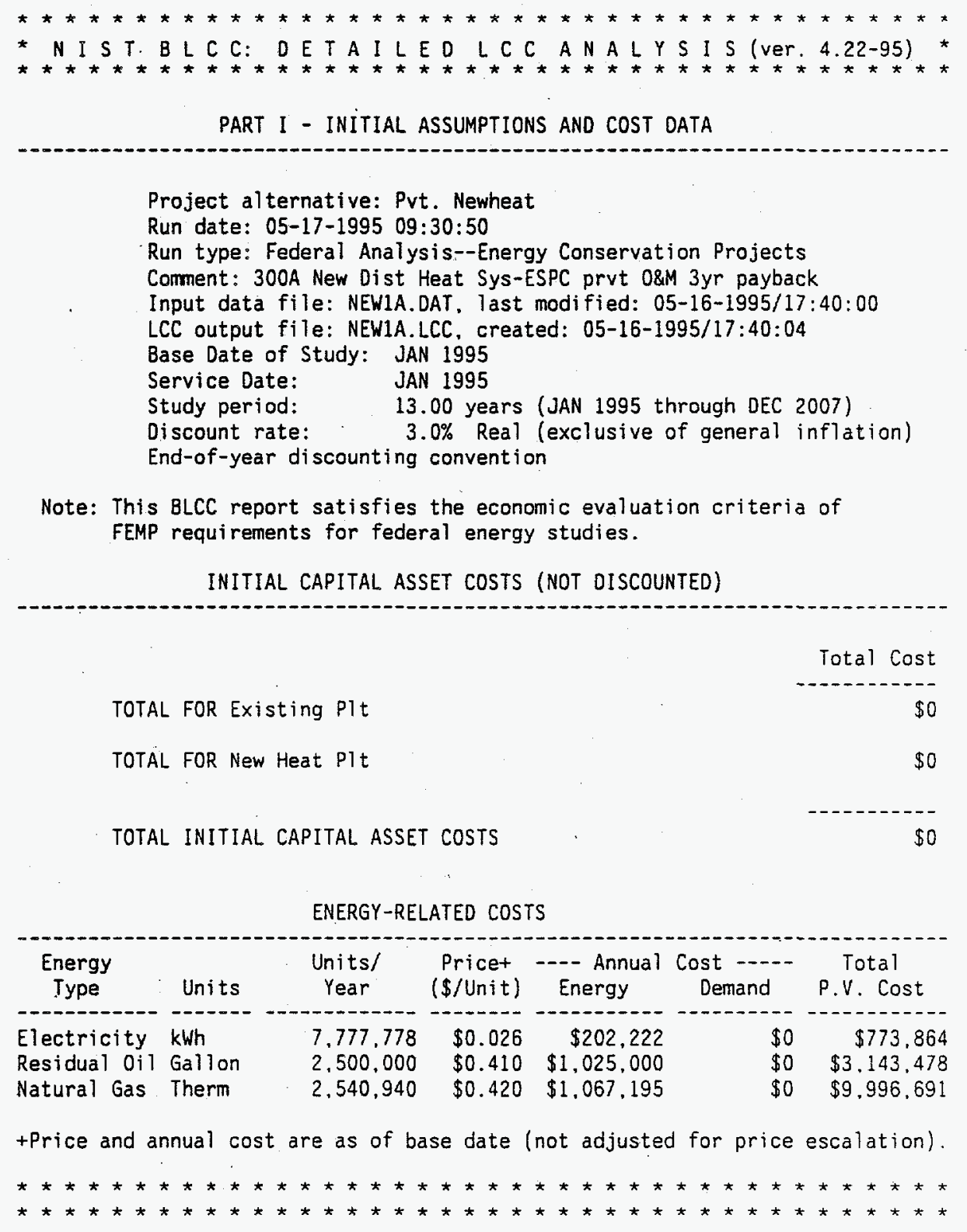


PART II - LIFE-CYCLE COST ANALYSIS

Discount Rate $=3.0 \%$ Real (exclusive of general inflation)

PROJECT ALTERNATIVE: Pvt. Newheat

RUN DATE: 05-17-1995/09:30:50

PRESENT VALUE

(1995 OOLLARS)

ANNUAL VALUE

(1995 DOLLARS)

CASH REQUIREMENTS AS OF SERVICE DATE

$\$ 0$

$\$ 0$

OPERATING, MAINTENANCE \& REPAIR COSTS:

Existing P1t:

NON-ANNUALLY RECURRING COSTS

$\$ 24,408,500$

$\$ 2.295 .122$

New Heat P1t:

NON-ANNUALLY RECURRING COSTS

$\$ 6,353,906$

$\$ 597.455$

SUBTOTAL

$\$ 30,762,400$

$\$ 2,892,577$

ENERGY COSTS

$\$ 13,914,030$

$\$ 1,308,331$

REPLACEMENTS TO. CAPITAL COMPONENTS

Existing P1t

New Heat P1t

SUBTOTAL

\begin{tabular}{rr}
$\$ 17.010 .010$ & $\$ 1,599.445$ \\
\hline$\$ 17.010,010$ & $\$ 1.599,445$
\end{tabular}

RESALE VALUE OF ORIG CAPITAL COMPONENTS

Existing Plt

New Heat P1t

SUBTOTAL

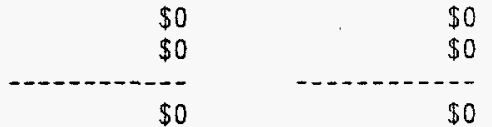

RESALE VALUE OF CAPITAL REPLACEMENTS

Existing P1t

New Heat Plt

\begin{tabular}{rr}
$\$ 0$ & $\$ 0$ \\
$\$ 5.833 .114$ & $\$ 548.485$ \\
\hline 55.833 .114 & $\$ 548.485$
\end{tabular}

SUBTOTAL

$\$ 55,853,340$

$\$ 5,251,868$ 


\begin{tabular}{lrrr}
\multicolumn{4}{c}{ PART III - EMISSIONS SUMMARY la } \\
$\begin{array}{c}\text { Energy } \\
\text { Type }\end{array}$ & $\begin{array}{c}\text { Annual } \\
\text { Emissions } \\
\text { (before) }\end{array}$ & $\begin{array}{c}\text { Annual } \\
\text { Emissions } \\
\text { (after) }\end{array}$ & $\begin{array}{r}\text { Life-cycle } \\
\text { Emissions }\end{array}$ \\
\hline Electricity:
\end{tabular}

la Based on emission factors from file EMISSION.FIL

lb Includes effects of annual energy usage indices, if used.

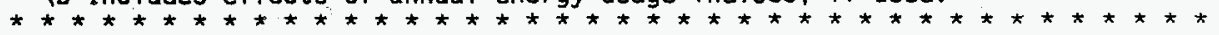



* NIST BLC C C A S H FLOW A N A Y Y I S (version 4.22-95)*

PROJECT ALTERNATIVE: Prt. Newheat

COMMENT: 300A New Dist Heat Sys-ESPC prvt 0\&M 3yr payback RUN DATE: 05-17-1995 09:33:32

INPUT DATA FILE: NEW1A.DAT, LAST MODIFIED 05-16-1995/17:40:00

STUDY PERIOD: 13.00 YEARS (JAN 1995 THROUGH DEC 2007)

ANALYSIS TYPE: Federal Analysis--Energy Conservation Projects

All costs in constant 1995 dollars (i.e.. excluding general inflation)

$\begin{array}{lrrr}\text { INITIAL CAPITAL COSTS } & \\ \text { COMPONENT: } & \text { (1) } & (2) & \begin{array}{c}\text { TOTAL } \\ \text { YEAR }\end{array} \\ \text { BEGINNING } & \text { Existing } & \text { New Heat } & \\ \text { JAN 1995 } & 0 & 0 & 0 \\ \text { TOTAL BY } & 0 & \text { TEAR) } \\ \text { COMPONENT } & 0 & 0 & 0\end{array}$

\begin{tabular}{|c|c|c|c|c|}
\hline $\begin{array}{c}\text { YEAR } \\
\text { BEGINNING }\end{array}$ & $\begin{array}{l}\text { INIT CAPITAL } \\
\text { INVESTMENT }\end{array}$ & $\begin{array}{l}\text { CAPITAL } \\
\text { REPLACEMENTS }\end{array}$ & $\begin{array}{l}\text { CAPITAL } \\
\text { DISPOSAL }\end{array}$ & $\begin{array}{l}\text { TOTAL CAP. } \\
\text { INVESTMENT }\end{array}$ \\
\hline - & - & --ー----- & ---n-- & $-\ldots+n$ \\
\hline JAN 1995 & 0 & 0 & 0 & 0 \\
\hline JAN 1996 & 0 & 0 & 0 & 0 \\
\hline JAN 1997 & 0 & 0 & 0 & 0 \\
\hline JAN 1998 & 0 & $6,474,770$ & 0 & $6.474,770$ \\
\hline JAN 1999 & 0 & $6.474,770$ & 0 & 6.474 .770 \\
\hline JAN 2000 & 0 & $6,474,770$ & 0 & 6.474 .770 \\
\hline JAN 2001 & 0 & 0 & 0 & 0 \\
\hline JAN 2002 & 0 & 0 & 0 & 0 \\
\hline JAN 2003 & 0 & 0 & 0 & 0 \\
\hline JAN 2004 & 0 & 0 & 0 & 0 \\
\hline JAN 2005 & 0 & 0 & 0 & 0 \\
\hline JAN 2006 & 0 & 0 & 0 & 0 \\
\hline JAN 2007 & 0 & 0 & $8,566,121$ & $-8,566,121$ \\
\hline TOTAL & 0 & $19,424,310$ & $8,566,121$ & $10,858,189$ \\
\hline
\end{tabular}

OPERATING-RELATED COSTS DURING SERVICE PERIOD:

\begin{tabular}{|c|c|c|c|c|c|}
\hline $\begin{array}{c}\text { YEAR } \\
\text { BEGINNING }\end{array}$ & ANNUAL & $\begin{array}{l}\text { OPERATING-RE } \\
\text { NON-ANNUAL }\end{array}$ & $\begin{array}{c}\text { ATED COSTS } \\
\text { ENERGY }\end{array}$ & WATER & $\begin{array}{l}\text { TOTAL } \\
\text { OPER. COST }\end{array}$ \\
\hline 301005 & & & $1200<2$ & & \\
\hline $\begin{array}{ll}\text { JAN } & 1995 \\
\text { JAN } & 1996\end{array}$ & & $\begin{array}{l}8,510,000 \\
8,510,000\end{array}$ & $\begin{array}{l}1,280,521 \\
1,312,514\end{array}$ & $\begin{array}{l}0 \\
0\end{array}$ & $\begin{array}{l}9.790,521 \\
9.822 .514\end{array}$ \\
\hline JAN 1997 & & $8,510,000$ & $1,350,221$ & 0 & 9.860 .221 \\
\hline JAN 1998 & & 802,000 & $1,196.634$ & 0 & $1,998,634$ \\
\hline JAN 1999 & & 802,000 & $1,212,749$ & 0 & $2,014.749$ \\
\hline JAN 2000 & & 802,000 & $1,234.242$ & 0 & 2.036 .242 \\
\hline JAN 2001 & & 802,000 & $1,267,555$ & 0 & $2,069,555$ \\
\hline JAN 2002 & & 802.000 & $1.294,300$ & 0 & 2.096 .300 \\
\hline JAN 2003 & & 802,000 & $1,314,229$ & 0 & $2,116,230$ \\
\hline JAN 2004 & & 802,000 & $1,355,229$ & 0 & $2,157,230$ \\
\hline JAN 2005 & & 802,000 & $1,384,676$ & 0 & $2,186,677$ \\
\hline JAN 2006 & & 802,000 & 1.409 .673 & 0 & 2.211 .673 \\
\hline JAN 2007 & & 802,000 & $1,465,509$ & 0 & $2,267,510$ \\
\hline TOTAL & & 33.550 .000 & 17.078 .054 & 0 & $50.628,056$ \\
\hline
\end{tabular}


SUM OF ALL CASH FLOWS (showing residual value)

\begin{tabular}{lrrr}
$\begin{array}{c}\text { YEAR } \\
\text { BEGINNING }\end{array}$ & $\begin{array}{c}\text { CAPITAL } \\
\text { INVESTMENT }\end{array}$ & $\begin{array}{c}\text { OPERATING } \\
\text { COSTS }\end{array}$ & $\begin{array}{r}\text { TOTAL } \\
\text { COST }\end{array}$ \\
\hline JAN 1995 & 0 & $9,790,521$ & $9.790,521$ \\
JAN 1996 & 0 & $9,822,514$ & $9,822,514$ \\
JAN 1997 & 0 & $9,860,221$ & $9,860,221$ \\
JAN 1998 & $6,474,770$ & $1,998,634$ & $8,473,404$ \\
JAN 1999 & $6,474,770$ & $2,014,749$ & $8,489,519$ \\
JAN 2000 & $6,474,770$ & $2,036,242$ & $8,511,012$ \\
JAN 2001 & 0 & $2,069,555$ & $2,069,555$ \\
JAN 2002 & 0 & $2,096,300$ & $2,096,300$ \\
JAN 2003 & 0 & $2,116,230$ & $2,116,230$ \\
JAN 2004 & 0 & $2,157,230$ & $2,157,230$ \\
JAN 2005 & 0 & $2,186,677$ & $2,186,677$ \\
JAN 2006 & 0 & $2,211,673$ & $2,211,673$ \\
JAN 2007 & $-8,566,121$ & $2,267,510$ & $-6,298,612$ \\
TOTAL & $10,858,189$ & $50,628,056$ & $61,486,244$
\end{tabular}

SUM OF ALL CASH FLOWS (w/o showing residual value)

\begin{tabular}{crrr}
$\begin{array}{c}\text { YEAR } \\
\text { BEGINNING }\end{array}$ & $\begin{array}{r}\text { CAPITAL } \\
\text { INVESTMENT }\end{array}$ & $\begin{array}{c}\text { OPERATING } \\
\text { COSTS }\end{array}$ & $\begin{array}{r}\text { TOTAL } \\
\text { COST }\end{array}$ \\
\hdashline JAN 1995 & 0 & $9,790,521$ & $9,790,521$ \\
JAN 1996 & 0 & $9,822,514$ & $9,822,514$ \\
JAN 1997 & 0 & $9,860,221$ & $9,860,221$ \\
JAN 1998 & $6,474,770$ & $1,998,634$ & $8,473,404$ \\
JAN 1999 & $6,474,770$ & $2,014,749$ & $8,489,519$ \\
JAN 2000 & $6,474,770$ & $2,036,242$ & $8,511,012$ \\
JAN 2001 & 0 & $2,069,555$ & $2,069,555$ \\
JAN 2002 & 0 & $2,096,300$ & $2,096.300$ \\
JAN 2003 & 0 & $2,116,230$ & $2,116,230$ \\
JAN 2004 & 0 & $2,157,230$ & $2,157,230$ \\
JAN 2005 & 0 & $2,186,677$ & $2,186,677$ \\
JAN 2006 & 0 & $2,211,673$ & $2,211,673$ \\
JAN 2007 & 0 & $2,267,510$ & $2,267,510$ \\
TOTAL & $19,424,310$ & $50.628,056$ & $70,052,366$
\end{tabular}


Appendix E

Life-Cycle Cost Analysis for New Distributed Heating System, 13-Year Study Period and 10-Year Loan Repayment Period 


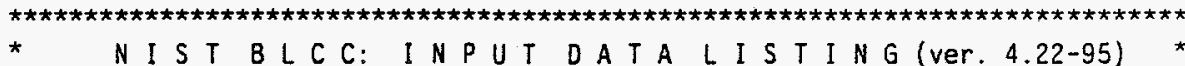

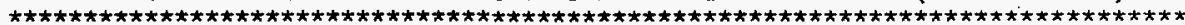

FILE NAME: NEW1B

FILE LAST MODIFIED ON 05-17-1995/11:16:56

PROJECT ALTERNATIVE: Pvt. Newheat

COMMENT: 300A New Dist Heat Sys-ESPC prvt 0\&M 10yr payback

GENERAL DATA:

ANALYSIS TYPE: Federal Analysis--Energy Conservation Projects

BASE DATE FOR LCC ANALYSIS: JAN 1995

STUDY PERIOD: 13 YEARS, O MONTHS

SERVICE DATE: JAN 1995

DISCOUNT AND INTEREST RATES ARE Real (exclusive of general inflation)

DISCOUNT RATE: $3.0 \%$

Escalation rates do not include general inflation

CAPITAL ASSET COST DATA:

NUMBER OF CAPITAL COMPONENTS: 3

COMPONENT NAME:

INITIAL COST (BASE YEAR \$)

EXPECTED ASSET LIFE (YRS/MTHS)

RESALE VALUE FACTOR

NUMBER OF REPLACEMENTS

$\begin{array}{ccc}\text { Existing Plt } & \text { New Heat Plt } & \text { More New Heat } \\ 0 & 0 & 0 \\ 3 / 0 & 0 / 0 & 0 / 0 \\ 0.00 \% & 0.00 \% & 0.00 \% \\ 0 & 8 & 2\end{array}$

REPLACEMENTS TO CAPITAL ASSETS:

REPLACEMENTS TO New Heat PIt:

REPLACEMENT NUMBER

YEARS/MONTHS FROM SERVICE DATE

INITIAL COST (BASE YEAR \$)

EXPECTED REPL. LIFE (YRS/MTHS)

RESALE VALUE FACTOR

1
$3 / 6$
$2,493,450$
$30 / 0$
$34.30 \%$

2
$4 / 6$
2.493 .450
$29 / 0$
$34.30 \%$

3
$5 / 6$
2.493 .450
$28 / 0$
$34.30 \%$

4
$6 / 6$
$2,493,450$
$27 / 0$
$34.30 \%$

REPLACEMENTS TO New Heat Plt:

REPLACEMENT NUMBER

YEARS/MONTHS FROM SERVICE DATE

INITIAL COST (BASE YEAR \$)

EXPECTED REPL. LIFE (YRS/MTHS)

RESALE VALUE FACTOR

5
$7 / 6$
2.493 .450
$26 / 0$
$34.30 \%$
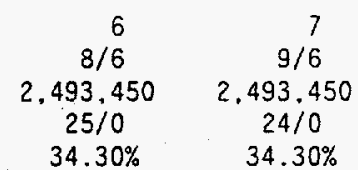
$10 / 6$
$2,493,450$
$23 / 0$

REPLACEMENTS TO More New Heat:

REPLACEMENT NUMBER

YEARS/MONTHS FROM SERVICE DATE

INITIAL COST (BASE YEAR \$)

EXPECTED REPL. LIFE (YRS/MTHS)

RESALE VALUE FACTOR

$\begin{array}{cc}1 & 2 \\ 11 / 6 & 12 / 6 \\ 2.493,450 & 2,493,450 \\ 24 / 0 & 23 / 0 \\ 34.30 \% & 34.30 \%\end{array}$


OPERATING, MAINTENANCE, AND REPAIR COST DATA BY COMPONENT:

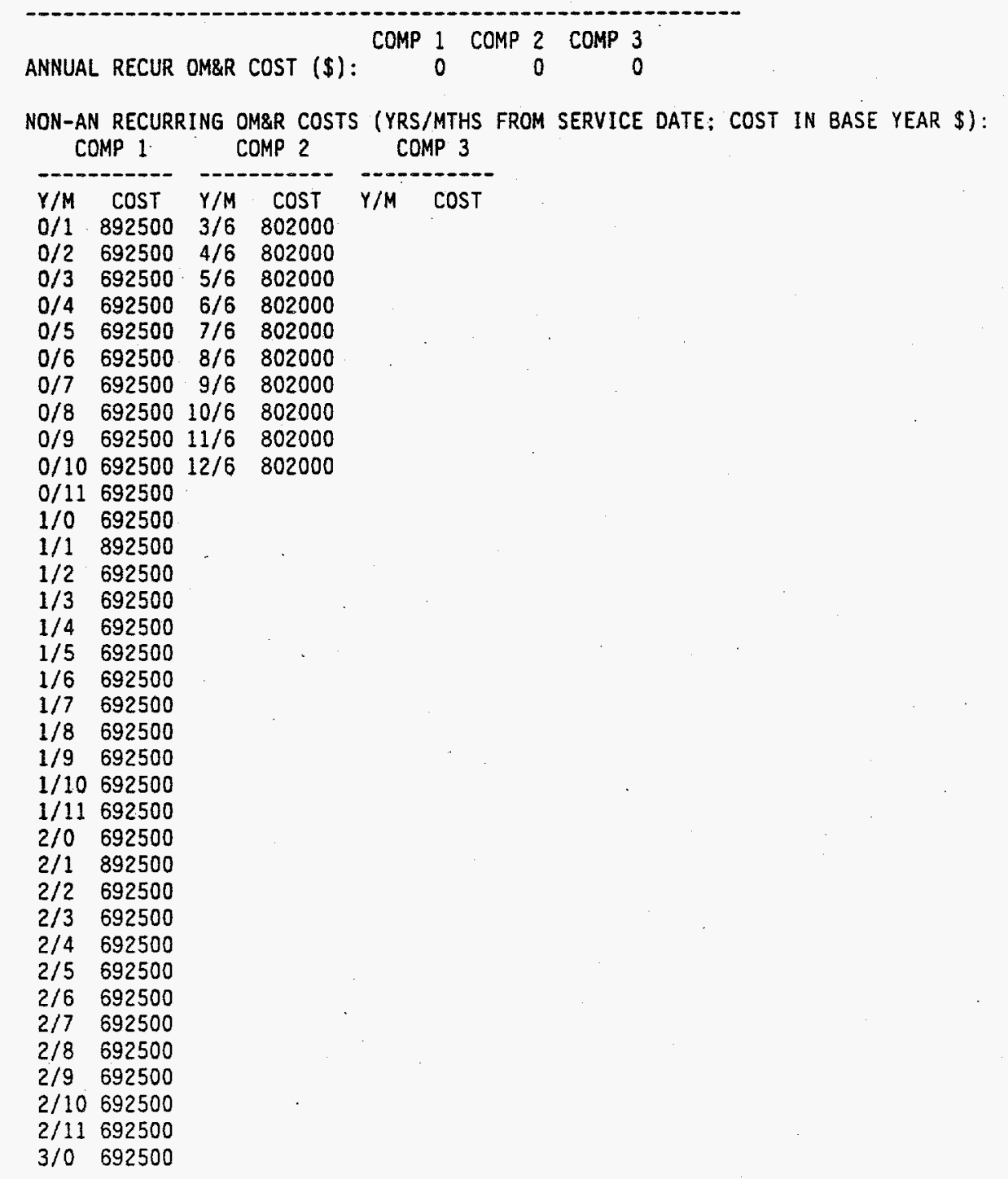


ENERGY-RELATED DATA :

NUMBER OF ENERGY TYPES $=3$

DOE energy price escalation rates filename: ENCOST95

DOE region (state code): 4 (WA)

DOE rate schedule type: Industrial

Underlying gen. inflation rate used with DOE rates: $0.00 \%$

ENERGY TYPE:

(A)

(B)

(C)

BASE ANNUAL CONSUMPTION:

UNITS:

PRICE PER UNIT (\$):

ANNUAL DEMAND CHARGE (\$): ESCALATION RATE METHOD:

$\begin{array}{ccc}\text { Electricity } & \text { Residual } 0 i 1 & \text { Natural Gas } \\ 7.777 .778 & 2.500 .000 & 2.540 .940 \\ \text { kWh } & \text { Galion } & \text { Therm } \\ 0.026 & 0.410 & 0.420 \\ 0.00 & 0.00 & 0.00 \\ \text { DOE rates } & \text { DOE rates } & \text { DOE rates }\end{array}$

$\begin{array}{rrrr}1995 & 0.43 & 5.12 & 3.13 \\ 1996 & -0.23 & 3.01 & 2.18 \\ 1997 & -0.56 & 3.50 & 2.25 \\ 1998 & -0.26 & 3.82 & 1.86 \\ 1999 & 0.56 & 3.67 & 1.36 \\ 2000 & 0.96 & 4.45 & 1.79 \\ 2001 & 0.49 & 4.54 & 2.75 \\ 2002 & -0.07 & 3.85 & 2.16 \\ 2003 & 0.07 & 3.93 & 1.57 \\ 2004 & -0.13 & 3.46 & 3.19 \\ 2005 & -0.49 & 2.05 & 2.22 \\ 2006 & -0.33 & 2.10 & 1.85 \\ 2007 & 0.33 & 2.89 & 4.03 \\ 2008 & 0.59 & 1.92 & 2.98\end{array}$

ENERGY TYPE:

Electricity Residual Oil Natural Gas

ENERGY USE INDEXES BY YEAR:

$\begin{array}{lrrr}1995 & 100.00 & 100.00 & 0.00 \\ 1996 & 100.00 & 100.00 & 0.00 \\ 1997 & 100.00 & 100.00 & 0.00 \\ 1998 & 12.66 & 0.00 & 100.00 \\ 1999 & 12.66 & 0.00 & 100.00 \\ 2000 & 12.66 & 0.00 & 100.00 \\ 2001 & 12.66 & 0.00 & 100.00 \\ 2002 & 12.66 & 0.00 & 100.00 \\ 2003 & 12.66 & 0.00 & 100.00 \\ 2004 & 12.66 & 0.00 & 100.00 \\ 2005 & 12.66 & 0.00 & 100.00 \\ 2006 & 12.66 & 0.00 & 100.00 \\ 2007 & 12.66 & 0.00 & 100.00\end{array}$

\section{E. 3}




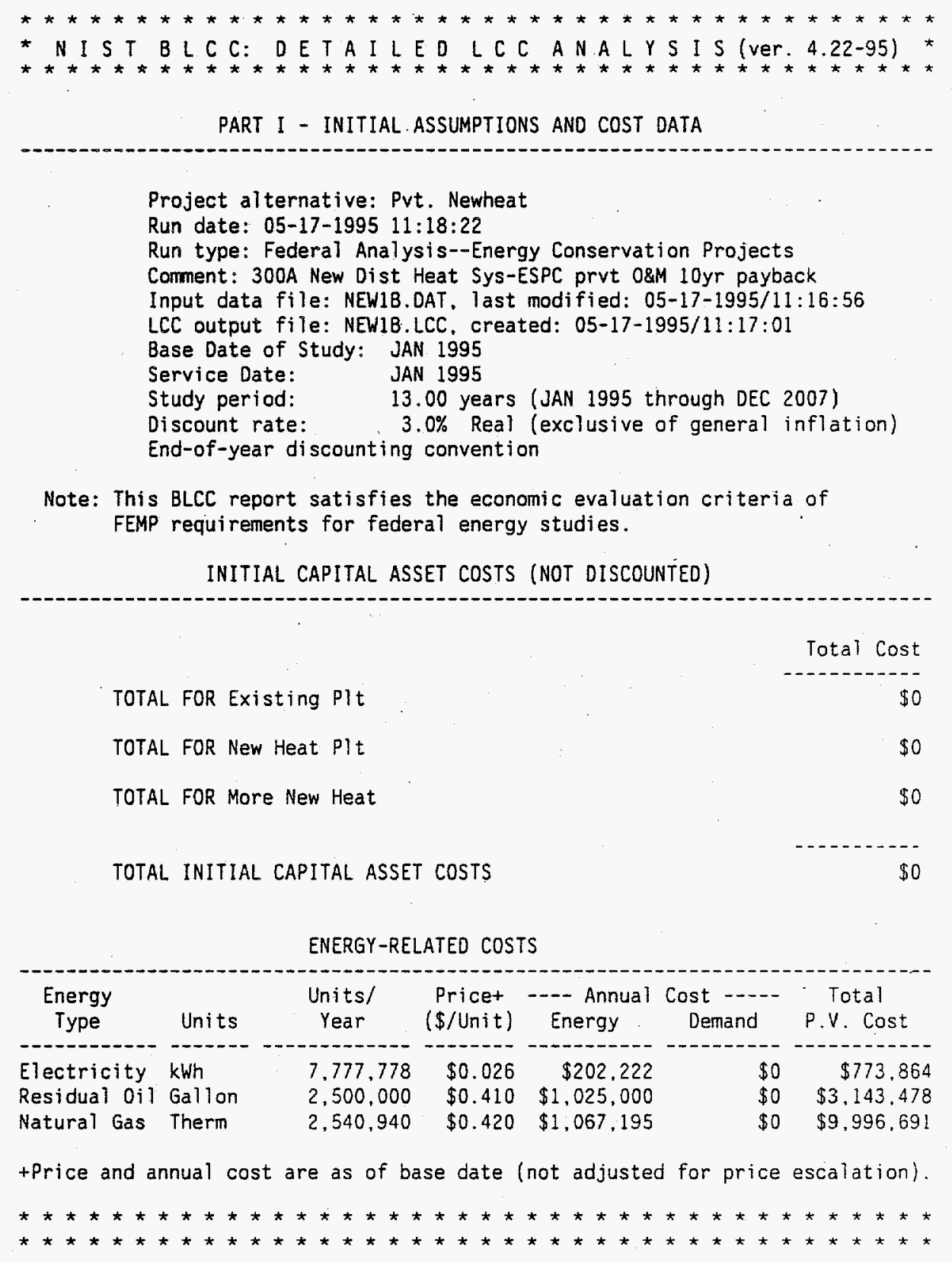

E. 4 
PART II - LIFE-CYCLE COST ANALYSIS

Discount Rate $=3.0 \%$ Real (exclusive of general inflation)

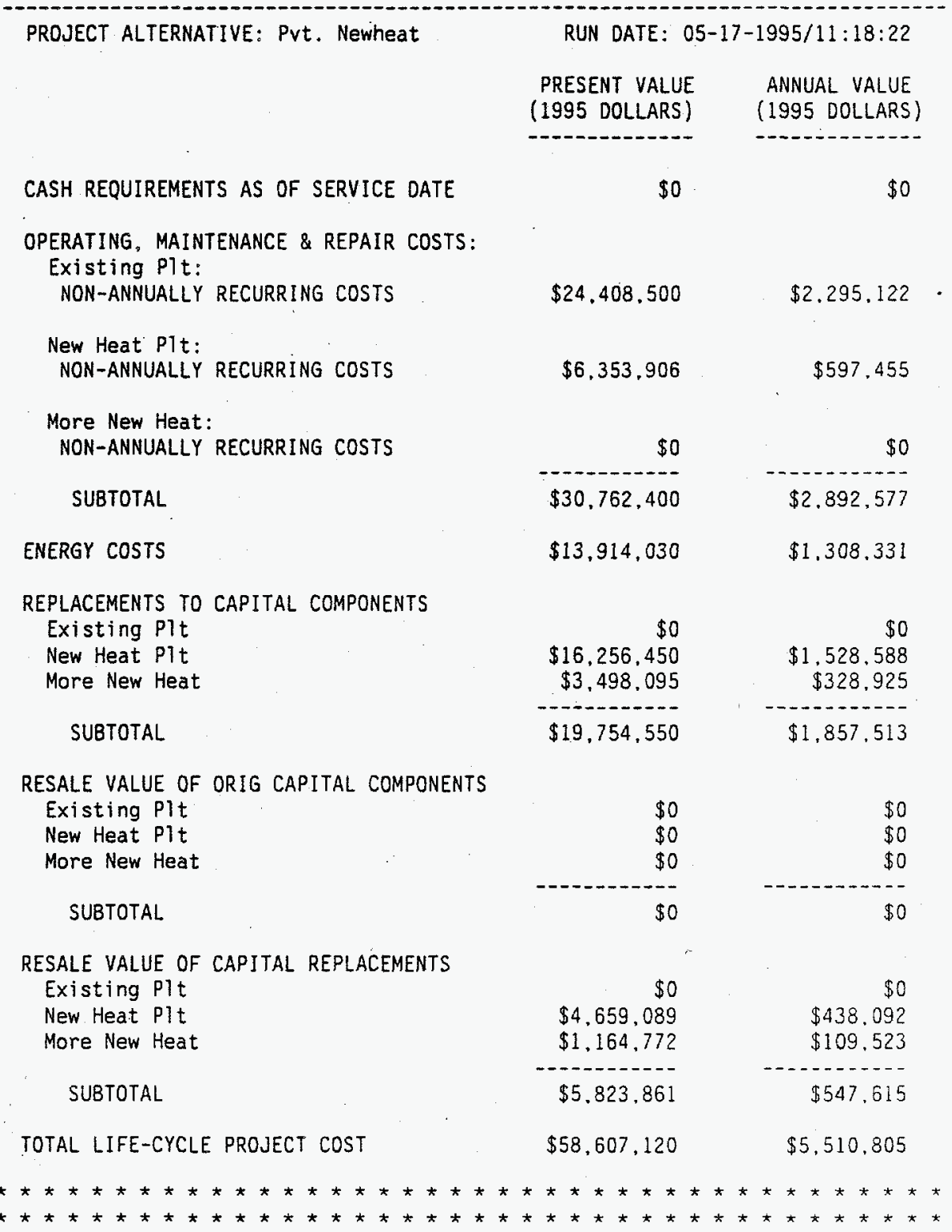

E.5 
PART III - EMISSIONS SUMMARY la

Energy
Type

Annual
Emissions
(before)

Annual

Emissions

Life-cycle

Electricity:

$\mathrm{CO2}(\mathrm{Mg})$ :

SOX (Kg):

NOX $(\mathrm{Kg})$ :

Residual 0il:

$\mathrm{CO2}(\mathrm{Mg})$ :

SOX (Kg):

NOX $(\mathrm{Kg})$ :

Natural Gas:

$\mathrm{CO2}(\mathrm{Mg})$ :

SOX $(\mathrm{Kg})$ :

NOX $(\mathrm{Kg})$ :

Total:

$\mathrm{CO} 2(\mathrm{Mg})$ :

SOX $(\mathrm{Kg})$ :

NOX (Kg):

$4,518.0$
37.959 .8
$19,378.1$
$28,656.8$
145.687 .7
$61,917.3$

(after)

Emissions $\backslash b$

--.--.-.-.-.

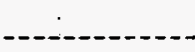

$4,805.7$

19.274

$2,453.3$

111.360

82.667

85.970

437.063

$.185,752$

13.418 .7

76.2

134.187

762

10.163 .8

101.638

33.174 .8

13.990 .7

239.431

$183,647.5$

$4,881.9$

549.186

81.295 .4

$12,617.1$

370.056

la Based on emission factors from file EMISSION.FIL

lb includes effects of annual energy usage indices, if used.

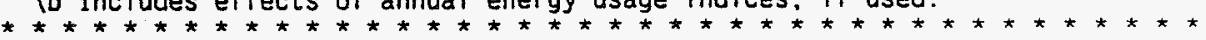


PROJECT ALTERNATIVE: Pvt. Newheat

COMMENT: 300A New Dist Heat Sys-ESPC prvt 08M 10yr payback

RUN DATE: 05-17-1995 11:18:36

INPUT DATA FILE: NEW1B.DAT, LAST MODIFIED 05-17-1995/11:16:56

STUDY PERIOD:

13.00 YEARS (JAN 1995 THROUGH DEC 2007)

ANALYSIS TYPE: Federal Analysis--Energy Conservation Projects

All costs in constant 1995 dollars (i.e., excluding general inflation)

$\begin{array}{lrrrr}\text { COMPONENT: } & \begin{array}{l}\text { INITIAL CAPITAL COSTS } \\ \text { (1) }\end{array} & \text { (2) } & \text { (3) } & \begin{array}{c}\text { TOTAL } \\ \text { YEAR }\end{array} \\ \text { BEGINNING } & \text { Existing } & \text { New Heat } & \text { More New } & \text { (BY YEAR) } \\ \text { JAN 1995 } & 0 & 0 & 0 & 0 \\ \text { TOTAL BY } & 0 & 0 & 0 & 0 \\ \text { COMPONENT } & 0 & 0 & 0 & 0\end{array}$

CAPITAL INVESTMENT COSTS

\begin{tabular}{|c|c|c|c|c|}
\hline $\begin{array}{c}\text { YEAR } \\
\text { BEGINNING }\end{array}$ & $\begin{array}{l}\text { INIT CAPITAL } \\
\text { INVESTMENT }\end{array}$ & $\begin{array}{c}\text { CAPITAL } \\
\text { REPLACEMENTS }\end{array}$ & $\begin{array}{l}\text { CAPITAL } \\
\text { DISPOSAL }\end{array}$ & $\begin{array}{l}\text { TOTAL CAP. } \\
\text { INVESTMENT }\end{array}$ \\
\hline - n-n-n-n & & - & - - n- & \\
\hline JAN 1995 & 0 & 0 & 0 & 0 \\
\hline JAN 1996 & 0 & 0 & 0 & \\
\hline JAN 1997 & 0 & 0 & 0 & 0 \\
\hline JAN 1998 & 0 & $2,493.450$ & 0 & 2.493 .450 \\
\hline JAN 1999 & 0 & $2.493,450$ & 0 & 2.493 .450 \\
\hline JAN 2000 & 0 & 2.493 .450 & 0 & 2.493 .450 \\
\hline JAN 2001 & 0 & $2,493,450$ & 0 & $2,493,450$ \\
\hline JAN 2002 & 0 & $2,493,450$ & 0 & 2.493 .450 \\
\hline JAN 2003 & 0 & $2,493,450$ & 0 & $2,493,450$ \\
\hline JAN 2004 & 0 & $2,493,450$ & 0 & $2,493,450$ \\
\hline JAN 2005 & 0 & $2,493,450$ & 0 & $2,493,450$ \\
\hline JAN 2006 & 0 & $2,493,450$ & 0 & $2,493,450$ \\
\hline JAN 2007 & 0 & $2,493,450$ & $8,552,534$ & $-6,059,084$ \\
\hline TOTAL & 0 & $24,934,500$ & $8,552,534$ & 16.381 .966 \\
\hline
\end{tabular}

OPERATING-RELATED COSTS DURING SERVICE PERIOD:

\begin{tabular}{|c|c|c|c|c|c|}
\hline $\begin{array}{l}\text { YEAR } \\
\text { BEGINNING }\end{array}$ & ANNUAL & $\begin{array}{l}\text { OPERATING-REL } \\
\text { NON-ANNUAL }\end{array}$ & $\begin{array}{c}\text { ATED COSTS } \\
\text { ENERGY }\end{array}$ & WATER & $\begin{array}{l}\text { TOTAL } \\
\text { OPER. COST }\end{array}$ \\
\hline - & & & & & \\
\hline JAN 1995 & 0 & $8,510,000$ & $1,280,521$ & 0 & $9,790,521$ \\
\hline JAN 1996 & 0 & $8,510,000$ & $1,312,514$ & 0 & $9,822,514$ \\
\hline JAN 1997 & 0 & $8,510,000$ & $1,350,221$ & 0 & $9,860.221$ \\
\hline JAN 1998 & 0 & 802,000 & $1,196,634$ & 0 & $1,998,634$ \\
\hline JAN 1999 & 0 & 802,000 & $1.212,749$ & 0 & 2.014 .749 \\
\hline JAN 2000 & 0 & 802,000 & $1,234,242$ & 0 & $2,036,242$ \\
\hline JAN 2001 & 0 & 802,000 & $1,267,555$ & 0 & $2,069,555$ \\
\hline JAN 2002 & 0 & 802,000 & $1,294,300$ & 0 & $2,096,300$ \\
\hline JAN 2003 & 0 & 802,000 & $1,314,229$ & 0 & 2.116 .230 \\
\hline JAN 2004 & 0 & 802,000 & 1,355 & 0 & $2,157,230$ \\
\hline JAN 2005 & 0 & 802,000 & $1.384,676$ & 0 & $2.186,677$ \\
\hline JAN 2006 & 0 & 802,000 & $1,409.673$ & 0 & 2.211 .673 \\
\hline JAN 2007 & 0 & 802.000 & 1.465 .509 & 0 & 2.267 .510 \\
\hline TOTAL & 0 & 33.550 .000 & $17,078,054$ & 0 & $50,628.056$ \\
\hline
\end{tabular}


SUM OF ALL CASH FLOWS (showing residual value)

\begin{tabular}{lrrr}
$\begin{array}{c}\text { YEAR } \\
\text { BEGINNING }\end{array}$ & $\begin{array}{r}\text { CAPITAL } \\
\text { INVESTMENT }\end{array}$ & $\begin{array}{c}\text { OPERATING } \\
\text { COSTS }\end{array}$ & $\begin{array}{r}\text { TOTAL } \\
\text { COST }\end{array}$ \\
\hline JAN 1995 & 0 & $9,790,521$ & $9,790,521$ \\
JAN 1996 & 0 & $9,822,514$ & $9,822,514$ \\
JAN 1997 & 0 & $9,860,221$ & $9.860,221$ \\
JAN 1998 & $2,493,450$ & $1,998,634$ & $4,492,084$ \\
JAN 1999 & $2,493,450$ & $2,014,749$ & $4,508,199$ \\
JAN 2000 & $2,493,450$ & $2,036,242$ & $4.529,692$ \\
JAN 2001 & $2,493,450$ & $2,069,555$ & $4,563,005$ \\
JAN 2002 & $2,493,450$ & $2,096,300$ & $4,589,750$ \\
JAN 2003 & $2,493,450$ & $2,116,230$ & $4,609,680$ \\
JAN 2004 & $2,493,450$ & $2,157,230$ & $4,650,680$ \\
JAN 2005 & $2,493,450$ & $2,186,677$ & $4,680,127$ \\
JAN 2006 & $2,493,450$ & $2,211,673$ & $4.705,123$ \\
JAN 2007 & $-6,059,084$ & $2,267,510$ & $-3,791,575$ \\
TOTAL & $16,381,966$ & $50,628,056$ & $67,010,024$
\end{tabular}

SUM OF ALL CASH FLOWS ( $w / 0$ showing residual value)

\begin{tabular}{lrrr}
$\begin{array}{c}\text { YEAR } \\
\text { BEGINNING }\end{array}$ & $\begin{array}{r}\text { CAPITAL } \\
\text { INVESTMENT }\end{array}$ & $\begin{array}{c}\text { OPERATING } \\
\text { COSTS }\end{array}$ & $\begin{array}{r}\text { TOTAL } \\
\text { COST }\end{array}$ \\
\hline JAN 1995 & 0 & $9,790,521$ & $9,790,521$ \\
JAN 1996 & $0,9,822,514$ & $9,822,514$ \\
JAN 1997 & 0 & $9,860,221$ & $9,860,221$ \\
JAN 1998 & $2,493,450$ & $1,998,634$ & $4,492,084$ \\
JAN 1999 & $2,493,450$ & $2,014,749$ & $4,508,199$ \\
JAN 2000 & $2,493,450$ & $2,036,242$ & $4,529,692$ \\
JAN 2001 & $2,493,450$ & $2,069,555$ & $4,563,005$ \\
JAN 2002 & $2,493,450$ & $2,096,300$ & $4,589,750$ \\
JAN 2003 & $2,493,450$ & $2,116,230$ & $4,609,680$ \\
JAN 2004 & $2,493,450$ & $2,157,230$ & $4,650,680$ \\
JAN 2005 & $2,493,450$ & $2,186,677$ & $4,680,127$ \\
JAN 2006 & $2,493,450$ & $2,211,673$ & $4,705,123$ \\
JAN 2007 & $2,493,450$ & $2,267,510$ & $4,760,960$ \\
TOTAL & $24,934,500$ & $50,628,056$ & $75,562,556$
\end{tabular}




\section{Appendix F}

\section{Life-Cycle Cost Analysis for Exisiting Central Steam Plant, 28-Year Study Period}


$* \quad N$ I ST $B$ L C C

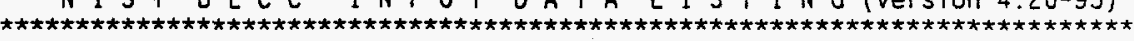

FILE NAME: STMPLT2

FILE LAST MODIFIED ON 01-21-1995/17:06:38

PROJECT ALTERNATIVE: STMPLT2

COMMENT: Existing 300 Area Central Steam Plant, 28 Yr Stdy

GENERAL DATA:

ANALYSIS TYPE: General LCC Analysis--Non-Federal, No Taxes

BASE DATE FOR LCC ANALYSIS: JAN 1995

STUDY PERIOD: 28 YEARS, $O$ MONTHS

SERVICE DATE: JAN 1995

DISCOUNT AND INTEREST RATES ARE Real (exclusive of generat inflation)

DISCOUNT RATE: $3.0 \%$

Escalation rates do not include general inflation

CAPITAL ASSET COST DATA:

NUMBER OF CAPITAL COMPONENTS: 3 COMPONENT NAME:

INITIAL COST (BASE YEAR \$)

EXPECTED ASSET LIFE (YRS/MTHS)

RESALE VALUE FACTOR

AVG PRICE ESC RATE(SERVICE PD)

NUMBER OF REPLACEMENTS

REPLACEMENTS TO CAPITAL ASSETS:

REPLACEMENTS TO BOiler House:

REPLACEMENT NUMBER

YEARS/MONTHS FROM SERVICE DATE

INITIAL COST (BASE YEAR \$)

EXPECTED REPL. LIFE (YRS/MTHS)

RESALE VALUE FACTOR

REPLACEMENTS TO Piping:

REPLACEMENT NUMBER

YEARS/MONTHS FROM SERVICE DATE

INITIAL COST (BASE YEAR \$)

EXPECTED REPL. LIFE (YRS/MTHS)

RESALE VALUE FACTOR

REPLACEMENTS TO Piping:

REPLACEMENT NUMBER

YEARS/MONTHS FROM SERVICE DATE

INITIAL COST (BASE YEAR \$)

EXPECTED REPL. LIFE (YRS/MTHS)

RESALE VALUE FACTOR

REPLACEMENTS TO General:

REPLACEMENT NUMBER

YEARS/MONTHS FROM SERVICE DATE

INITIAL COST (BASE YEAR \$)

EXPECTED REPL. LIFE (YRS/MTHS)

RESALE VALUE FACTOR

REPLACEMENTS TO Genera1:

REPLACEMENT NUMBER

YEARS/MONTHS FROM SERVICE DATE

INITIAL COST. (BASE YEAR \$)

EXPECTED REPL. LIFE (YRS/MTHS)

RESALE VALUE FACTOR

Boiler House
0
$0 / 0$
$0.00 \%$
$0.00 \%$
3

$\begin{array}{ccc}1 & 2 & 3 \\ 3 / 0 & 4 / 0 & 4 / 0 \\ \$ 1.000 .000 & \$ 9.999 .999 & \$ 5.000 .001 \\ 30 / 0 & 30 / 0 & 30 / 0 \\ 0.00 \% & 0.00 \% & 0.00 \%\end{array}$

1

$3 / 0$

$\$ 3,000,000$

$30 / 0$

$0.00 \%$

2
$5 / 0$
$\$ 9,999,999$
$30 / 0$
$0.00 \%$
3
$5 / 0$
$\$ 2,900,001$
$30 / 0$
$0.00 \%$
General
0
$0.00 \%$
$0.00 \%$
6

$\begin{array}{cccc}5 & 6 & & \\ 10 / 0 & 10 / 0 & & \\ \$ 9.999 .999 & \$ 500,002 & & \\ 30 / 0 & 30 / 0 & & \\ 0.00 \% & 0.00 \% & & \\ & & & 4 \\ 1 & & 3 & 20 / 0 \\ 8 / 0 & 12 / 0 & 16 / 0 & \$ 1.100 .000 \\ \$ 1.100,000 & \$ 1,100.000 & \$ 1.100 .000 & 30 / 0 \\ 30 / 0 & 30 / 0 & 30 / 0 & 0.00 \% \\ 0.00 \% & 0.00 \% & 0.00 \% & 0\end{array}$

$\begin{array}{cc}5 & 6 \\ 24 / 0 & 28 / 0 \\ \$ 1,100,000 & \$ 1,100.000 \\ 30 / 0 & 30 / 0 \\ 0.00 \% & 0.00 \%\end{array}$

F.1 
OPERATING, MAINTENANCE, AND REPAIR COST DATA BY COMPONENT:

$\begin{array}{lccc} & \text { COMP } 1 & \text { COMP } 2 & \text { COMP } 3 \\ \text { ANNUAL RECUR OM\&R COST (\$): } & \$ 8.310 .000 & 0 & \$ 200.000 \\ \text { ESCALATION RATE FOR OM\&R: } & 0.00 \% & 0.00 \% & 0.00 \%\end{array}$

No non-annually-recurring OM\&R costs reported.

ENERGY-RELATED DATA:

NUMBER OF ENERGY TYPES $=2$

DOE energy price escalation rates filename: ENCOST95

DOE region (state code): 4 (WA)

DOE rate schedule type: Industrial

Underlying gen. inflation rate used with DOE rates: $0.00 \%$

ENERGY TYPE:

TYPE 1

BASE ANNUAL CONSUMPTION:

UNITS:

PRICE PER UNIT (\$):

ANNUAL DEMAND CHARGE (\$):

ESCALATION RATE METHOD:

Residual $0 \mathrm{il}$. Electricity

$2,500,000 \quad 7.777,778$

Galion $\quad k W h$.

$0.410 \quad 0.026$

$0.00 \quad 0.00$

DOE rates DOE rates

$\begin{array}{lrr}1995 & 5.12 & 0.43 \\ 1996 & 3.01 & -0.23 \\ 1997 & 3.50 & -0.56 \\ 1998 & 3.82 & -0.26 \\ 1999 & 3.67 & 0.56 \\ 2000 & 4.45 & 0.96 \\ 2001 & 4.54 & 0.49 \\ 2002 & 3.85 & -0.07 \\ 2003 & 3.93 & 0.07 \\ 2004 & 3.46 & -0.13 \\ 2005 & 2.05 & -0.49 \\ 2006 & 2.10 & -0.33 \\ 2007 & 2.89 & 0.33 \\ 2008 & 1.92 & 0.59 \\ 2009 & 1.28 & 0.88 \\ 2010 & 2.13 & 0.90 \\ 2011 & 2.67 & 0.42 \\ 2012 & 2.69 & 0.41 \\ 2013 & 2.80 & 0.41 \\ 2014 & 2.73 & 0.41 \\ 2015 & 2.65 & 0.44 \\ 2016 & 2.75 & 0.41 \\ 2017 & 2.76 & 0.41 \\ 2018 & 2.68 & 0.43 \\ 2019 & 2.69 & 0.43 \\ 2020 & 2.70 & 0.40 \\ 2021 & 2.70 & 0.40 \\ 2022 & 2.77 & 0.43 \\ 2023 & 2.76 & 0.43\end{array}$




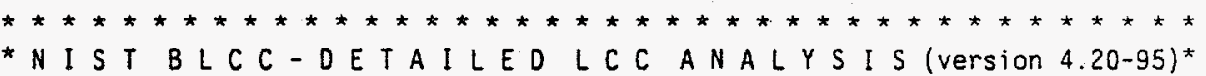

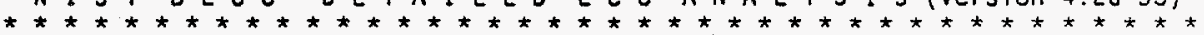

PART 1 - INITIAL ASSUMPTIONS AND COST DATA

Project alternative: STMPLT2

Run date: 01-21-1995 17:07:21

Run type: General LCC Analysis--Mon-Federal, No Taxes

Comment: Existing 300 Area Central Steam Plant, $28 \mathrm{Yr}$ Stdy

Input data file: STMPLT2.DAT, last modified: 01-21-1995/17:06:38

LCC output file: STMPLT2.LCC, created: 01-21-1995/17:06:45

Base Date of Study: JAN 1995

Service Date: JAN 1995

Study period: $\quad 28.00$ years (JAN 1995 through DEC 2022)

Discount rate: $\quad 3.0 \%$ Real (exclusive of general inflation)

End-of-year discounting convention

INITIAL CAPITAL ASSET COSTS (NOT DISCOUNTED)

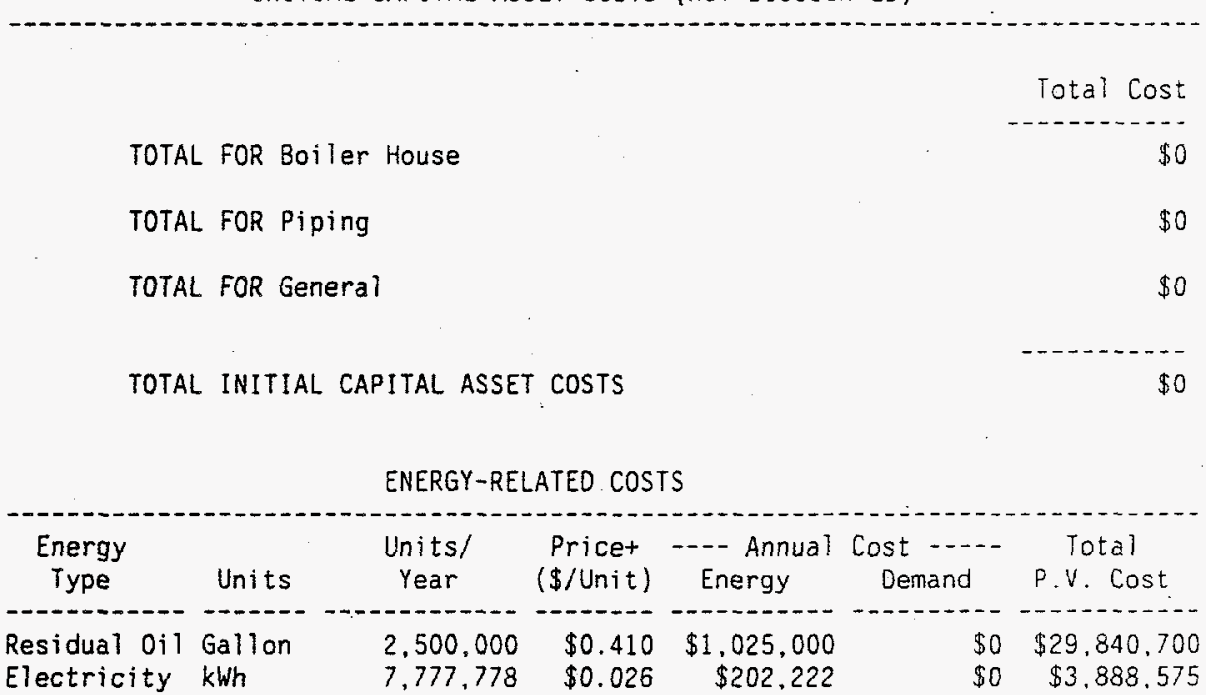

+ Price and annual cost are as of base date (not adjusted for price escalation).

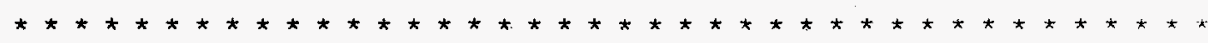

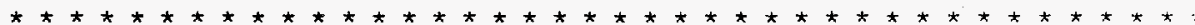


PART II - LIFE-CYCLE COST ANALYSIS

Discount Rate $=3.0 \%$ Real (exclusive of general inflation)

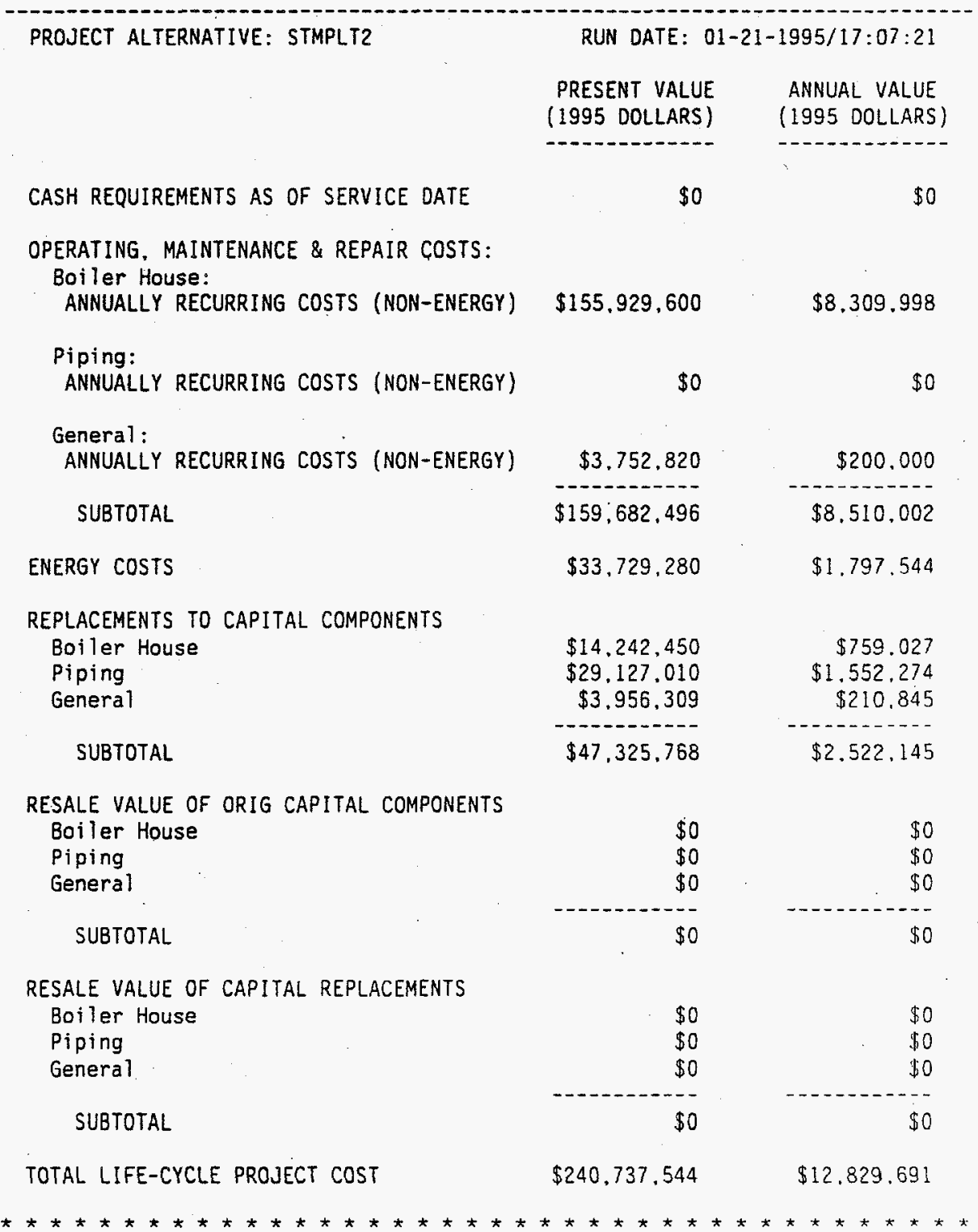

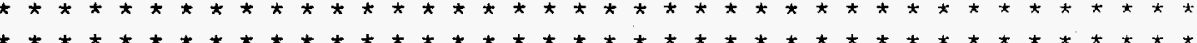


PART III - EMISSIONS SUMMARY la

\begin{tabular}{|c|c|c|}
\hline $\begin{array}{l}\text { Energy } \\
\text { Type }\end{array}$ & $\begin{array}{c}\text { Annual } \\
\text { Emissions }\end{array}$ & $\begin{array}{l}\text { Life-cycle } \\
\text { Emissions }\end{array}$ \\
\hline 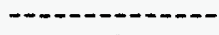 & - & \\
\hline \multicolumn{3}{|l|}{ Residual 0i1: } \\
\hline $\mathrm{CO} 2(\mathrm{Kg}):$ & $28,656,800.0$ & $802,389,000$ \\
\hline SOx $(\mathrm{Kg}):$ & $145,687.7$ & ??? \\
\hline NOX $(\mathrm{Kg}):$ & 61.917 .3 & $1.733,683$ \\
\hline \multicolumn{3}{|l|}{ Electricity: } \\
\hline $\mathrm{CO2}(\mathrm{Kg}):$ & $4.518,013.0$ & $126.504,400$ \\
\hline SOx $(\mathrm{Kg}):$ & 37.959 .8 & 547,001 \\
\hline NOX $(\mathrm{Kg}):$ & 19.378 .1 & 542,586 \\
\hline \multicolumn{3}{|l|}{ Total: } \\
\hline $\operatorname{co2}(\mathrm{Kg}):$ & $33,174,800.0$ & $928,894,000$ \\
\hline SOX $(\mathrm{Kg}):$ & $183,647.5$ & ??? \\
\hline NOx $(\mathrm{Kg}):$ & $81,295.3$ & $2,276,269$ \\
\hline
\end{tabular}

la Based on emission factors from file EMISSION.FIL

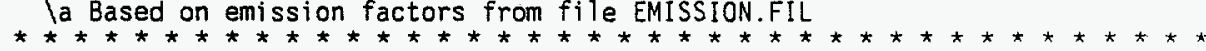


* NIST BLCC CASH FLOW ANALYSIS (version 4.20-95) *

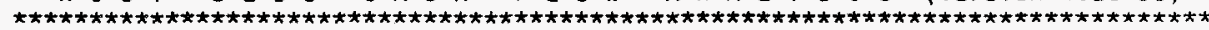

PROJECT ALTERNATIVE: STMPLT2

COMMENT: Existing 300 Area Central Steam Plant, 28 Yr Stdy

RUN DATE: 01-21-1995 17:07:36

INPUT DATA FILE: STMPLT2.DAT, LAST MODIFIED 01-21-1995/17:06:38

STUDY PERIOD:

28.00 YEARS (JAN 1995 THROUGH DEC 2022)

ANALYSIS TYPE: General LCC Analysis--Non-Federal. No Taxes

All costs in constant 1995 dollars (i.e., excluding general inflation)

\begin{tabular}{|c|c|c|c|c|}
\hline COMPONENT : & $\begin{array}{l}\text { INITIAL CAPI } \\
\text { (1) }\end{array}$ & $\begin{array}{l}\text { TAL COSTS } \\
\text { (2) }\end{array}$ & (3) & TOTA \\
\hline & & $-\cdots$ & & (BY YEAR) \\
\hline BEGINNING & Boiler & Piping & General & ---+-- \\
\hline JAN 1995 & 0 & 0 & 0 & 0 \\
\hline $\begin{array}{l}\text { TOTAL BY } \\
\text { COMPONENT }\end{array}$ & 0 & --- & 0 & 0 \\
\hline
\end{tabular}

CAPITAL INVESTMENT COSTS

\begin{tabular}{|c|c|c|c|c|}
\hline $\begin{array}{c}\text { YEAR } \\
\text { BEGINNING }\end{array}$ & $\begin{array}{l}\text { INIT CAPITAL } \\
\text { INVESTMENT }\end{array}$ & $\begin{array}{l}\text { CAPITAL } \\
\text { REPLACEMENTS }\end{array}$ & $\begin{array}{l}\text { CAPITAL } \\
\text { OISPOSAL }\end{array}$ & $\begin{array}{l}\text { 'TOTAL CAP. } \\
\text { INVESTMENT }\end{array}$ \\
\hline$-\ldots+n$ & $-1-$ & $--1-$ & - n & - n \\
\hline JAN 1995 & 0 & 0 & 0 & 0 \\
\hline JAN 1996 & 0 & 0 & 0 & 0 \\
\hline JAN 1997 & 0 & $4,000,000$ & 0 & $4,000,000$ \\
\hline JAN 1998 & 0 & 15.000 .000 & 0 & $15,000,000$ \\
\hline JAN 1999 & 0 & $12,900,000$ & 0 & $12.900,000$ \\
\hline JAN 2000 & 0 & 0 & 0 & 0 \\
\hline JAN 2001 & 0 & 0 & 0 & 0 \\
\hline JAN 2002 & 0 & 1.100 .000 & 0 & $1.100,000$ \\
\hline JAN 2003 & 0 & 0 & 0 & $\therefore 0$ \\
\hline JAN 2004 & 0 & $20,500,000$ & 0 & $20,500,000$ \\
\hline JAN 2005 & 0 & 0 & 0 & 0 \\
\hline JAN 2006 & 0 & $1.100,000$ & 0 & 1.100 .000 \\
\hline JAN 2007 & 0 & 0 & 0 & 0 \\
\hline JAN 2008 & 0 & 0 & 0 & 0 \\
\hline JAN 2009 & 0 & 0 & 0 & 0 \\
\hline JAN 2010 & 0 & $1,100,000$ & 0 & 1.100 .000 \\
\hline JAN 2011 & 0 & 0 & 0 & 0 \\
\hline JAN 2012 & 0 & 0 & 0 & 0 \\
\hline JAN 2013 & 0 & 0 & 0 & 0 \\
\hline JAN 2014 & 0 & $1.100,000$ & 0 & 1.100 .000 \\
\hline JAN 2015 & 0 & 0 & 0 & 0 \\
\hline JAN 2016 & 0 & 0 & 0 & 0 \\
\hline JAN 2017 & 0 & 0 & 0 & 0 \\
\hline JAN 2018 & 0 & $1,100,000$ & 0 & $1,100,000$ \\
\hline JAN 2019 & 0 & 0 & 0 & 0 \\
\hline JAN 2020 & 0 & 0 & 0 & 0 \\
\hline JAN 2021 & 0 & 0 & 0 & 0 \\
\hline JAN 2022 & 0 & $1,100,000$ & 0 & $1,100,000$ \\
\hline TOTAL & 0 & $59,000,000$ & 0 & 59.000 .000 \\
\hline
\end{tabular}


OPERATING-RELATED COSTS DURING SERVICE PERIOD:

\begin{tabular}{|c|c|c|c|c|c|}
\hline $\begin{array}{c}\text { YEAR } \\
\text { BEGINNING }\end{array}$ & ANNUAL & $\begin{array}{l}\text { OPERATING-RE } \\
\text { NON-ANNUAL }\end{array}$ & $\begin{array}{l}\text { LATEO COSTS } \\
\text { ENERGY }\end{array}$ & WATER & $\begin{array}{c}\text { TOTAL } \\
\text { OPER. COST }\end{array}$ \\
\hline JAN 1995 & $\$ 8,510,000$ & $\$$ & $\$ 1,280,521$ & $\$$ & $\$ 9,790,521$ \\
\hline JAN 1996 & $8,510,000$ & 0 & $1,312,514$ & & 9.822 .514 \\
\hline JAN 1997 & $8,510,000$ & 0 & $1.350,221$ & & $9,860,221$ \\
\hline JAN 1998 & $8,510,000$ & 0 & $1,393,543$ & & $9,903.543$ \\
\hline JAN 1999 & $8,510,000$ & 0 & $1,438,469$ & & $9,948,469$ \\
\hline JAN 2000 & $8,510,000$ & 0 & $1.495,378$ & & 10.005 .378 \\
\hline JAN 2001 & $8,510,000$ & 0 & $1,554,961$ & & 10.064 .961 \\
\hline JAN 2002 & $8,510,000$ & 0 & $1.606,767$ & & 10.116 .767 \\
\hline JAN 2003 & $8,510,000$ & 0 & $1,662,024$ & & 10.172 .024 \\
\hline JAN 2004 & $8,510,000$ & 0 & $1,712,209$ & & $10,222,209$ \\
\hline JAN 2005 & 8,51 & 0 & $1,742,159$ & & $10,252,159$ \\
\hline JAN 2006 & 8.51 & 0 & $1.773,816$ & & 10.283 .816 \\
\hline JAN 2007 & 8.5 & 0 & $1.819,925$ & & $10,329,924$ \\
\hline JAN 2008 & 8.51 & 0 & $1,852,099$ & & $10,362,099$ \\
\hline JAN 2009 & 8.51 & 0 & $1,874,961$ & & $10,384,961$ \\
\hline JAN 2010 & .000 & 0 & $1,912,433$ & & $10,422,433$ \\
\hline JAN 2011 & .000 & 0 & $1,958,743$ & & $10.468,743$ \\
\hline JAN 2012 & $8,510,000$ & 0 & $2,006,654$ & & 10.516 .654 \\
\hline JAN 2013 & 0,000 & 0 & $2,057,811$ & & 10.567 .811 \\
\hline JAN 2014 & .000 & 0 & $2,109,011$ & & 10.619 .011 \\
\hline JAN 2015 & .000 & 0 & $2,160,235$ & & 10.670 .235 \\
\hline JAN 2016 & .000 & 0 & $2,214,638$ & & 10.724 .638 \\
\hline JAN 2017 & & 0 & 2.270 .686 & & 10.780 .686 \\
\hline JAN 2018 & 8 & 0 & 2,32 & & 10.836 .800 \\
\hline JAN 2019 & & 0 & 2.384 .5 & & 10.894 .516 \\
\hline JAN 2020 & & 0 & $2,443,809$ & & 10.953 .809 \\
\hline JAN 2021 & .000 & 0 & 2.504 .704 & & $11,014,704$ \\
\hline JAN 2022 & 0,000 & 0 & $2,568,911$ & & $0 \quad 11.078 .911$ \\
\hline TOTAL & 80,000 & 0 & $\$ 52.788,500$ & & $0 \$ 291.068 .500$ \\
\hline
\end{tabular}


SUM OF ALL CASH FLOWS

\begin{tabular}{|c|c|c|c|}
\hline $\begin{array}{l}\text { YEAR } \\
\text { BEGINNING }\end{array}$ & $\begin{array}{l}\text { CAPITAL } \\
\text { INVESTMENT }\end{array}$ & $\begin{array}{l}\text { OPERATING } \\
\text { COSTS }\end{array}$ & $\begin{array}{l}\text { TOTAL } \\
\text { COST }\end{array}$ \\
\hline & & & \\
\hline JAN 1995 & $\$$ & $\$ 9.790,521$ & $\$ 9,790,521$ \\
\hline IN 1996 & 0 & 9.822 & 22,514 \\
\hline N 1997 & $4,000,000$ & 9.860. & 13, \\
\hline N 1998 & $15,000,000$ & $9.903,543$ & 24,9 \\
\hline IN 1999 & $12.900,000$ & 48,469 & 3.468 \\
\hline JAN 2000 & 0 & $10,005,378$ & 05,378 \\
\hline JAN 2001 & 0 & 10.064 .961 & 10.064 .961 \\
\hline AN 2002 & $1,100,000$ & 10.116 .767 & 11.216 .767 \\
\hline JAN 2003 & 0 & 24 & $10,172,024$ \\
\hline AN 2004 & $20.500,000$ & 22.209 & 2.208 \\
\hline iN 2005 & 0 & .159 & $\$ 2.159$ \\
\hline N 2006 & $1,100,000$ & & .816 \\
\hline AN 2007 & 0 & & 924 \\
\hline 008 & 0 & & .099 \\
\hline iN 2009 & 0 & & 961 \\
\hline N 2010 & $1,100,000$ & & .433 \\
\hline JAN 2011 & 0 & 10, & 10.4 \\
\hline JAN 2012 & 0 & 10, & 10,5 \\
\hline JAN 2013 & 0 & 10,567 & $10,567,811$ \\
\hline JAN 2014 & 1.100 .000 & $10.619,011$ & 11.719 .011 \\
\hline JAN 2015 & 0 & 10. & 70,235 \\
\hline JAN 2016 & 0 & 10,7 & 10.7 \\
\hline JAN 2017 & 0 & 10,7 & 10.7 \\
\hline JAN 2018 & $1,100,000$ & 10.8 & 11.936 .800 \\
\hline JAN 2019 & & & \\
\hline JAN 2020 & 0 & $10,953,809$ & 10.953 .809 \\
\hline JAN 2021 & & 11.014 .704 & 11.014 .704 \\
\hline JAN 2022 & & 11.078 .911 & 12.178 .911 \\
\hline & $\$ 59,000,000$ & $\$ 291,068,500$ & $\$ 350.068 .500$ \\
\hline
\end{tabular}


Appendix G

Life-Cycle Cost Analysis for New Distributed Heating System, 28-Year Study Period and 3-Year Loan Repayment Period 


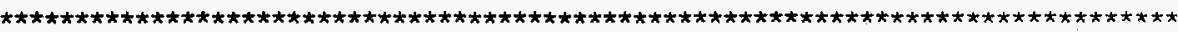

N I S T B L C C: IN PUT OA T A L I S T IN G (ver. 4.22-95)

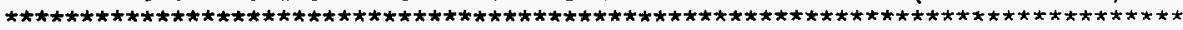

FILE NAME: NEW2A

FILE LAST MODIFIED ON 05-17-1995/15:17:18

PROJECT ALTERNATIVE: PVt. Newheat

COMMENT: 300A Dist Heat Sys-ESPC prvt 08M 3yr Pay 28yr std

GENERAL DATA:

ANALYSIS TYPE: General LCC Analysis--Non-Federal. No Taxes

BASE DATE FOR LCC ANALYSIS: JAN 1995

STUDY PERIOD: 28 YEARS, 0 MONTHS

SERVICE DATE: JAN 1995

DISCOUNT AND INTEREST RATES ARE Real (exclusive of general inflation)

OISCOUNT RATE: $3.0 \%$

Escalation rates do not include general inflation

CAPITAL ASSET COST DATA:

NUMBER OF CAPITAL COMPONENTS: 2 COMPONENT NAME:

INITIAL COST (BASE YEAR \$)

EXPECTED ASSET LIFE (YRS/MTHS)

RESALE VALUE FACTOR

AVG PRICE ESC RATE(SERVICE PD)

NUMBER OF REPLACEMENTS

$\begin{array}{cc}\text { Existing Plt } & \text { New Heat Plt } \\ 0 & 0 \\ 0 / 0 & 0 / 0 \\ 0.00 \% & 0.00 \% \\ 0.00 \% & 0.00 \% \\ 0 & 3\end{array}$

REPLACEMENTS TO CAPITAL ASSETS:

REPLACEMENTS TO New Heat PIt:

REPLACEMENT NUMBER

YEARS/MONTHS FROM SERVICE DATE

INITIAL COST (BASE YEAR \$)

EXPECTED REPL. LIFE (YRS/MTHS)

RESALE VALUE FACTOR

1
$3 / 6$
6.474 .770
$30 / 0$
$11.00 \%$

2
$4 / 6$
$6,474,770$
$29 / 0$
$11.00 \%$

3
$5 / 6$
6.474 .770
$28 / 0$
$11.00 \%$


OPERATING. MAINTENANCE, AND REPAIR COST DATA BY COMPONENT:

$\begin{array}{llll} & \text { COMP } 1 & \text { COMP } 2 \\ \text { ANNUAL RECUR OM\&R COST. (\$): } & 0 & 0 \\ \text { ESCALATION RATE FOR OM\&R: } & 0.00 \% & 0.00 \%\end{array}$

NON-AN RECURRING OM\&R COSTS (YRS/MTHS FROM SERVICE DATE: COST IN BASE YEAR $\$$ ): COMP 1 COMP 2

\begin{tabular}{|c|c|c|c|}
\hline & & & \\
\hline$Y / M$ & $\operatorname{Cos} T$ & $Y / M$ & $\operatorname{COST}$ \\
\hline $\begin{array}{l}0 / 1 \\
0 / 2\end{array}$ & $\begin{array}{l}692500 \\
892500\end{array}$ & $\begin{array}{l}3 / 6 \\
4 / 6\end{array}$ & $\begin{array}{l}802000 \\
802000\end{array}$ \\
\hline $0 / 3$ & 692500 & $5 / 6$ & 802000 \\
\hline $0 / 4$ & 692500 & $6 / 6$ & \\
\hline $0 / 5$ & 692500 & $7 / 6$ & 802000 \\
\hline $0 / 6$ & 692500 & $8 / 6$ & 802000 \\
\hline $0 / 7$ & 692500 & $9 / 6$ & 802000 \\
\hline $0 / 8$ & 692500 & $10 / 6$ & 802000 \\
\hline $0 / 9$ & 2500 & $11 / 6$ & 802000 \\
\hline $0 / 10$ & 692500 & $12 / 6$ & 802000 \\
\hline $0 / 11$ & 692500 & $13 / 6$ & 802000 \\
\hline $1 / 0$ & 692500 & $14 / 6$ & 802000 \\
\hline $1 / 1$ & 892500 & $15 / 6$ & 802000 \\
\hline $1 / 2$ & 692500 & $16 / 6$ & 802000 \\
\hline $1 / 3$ & 692500 & $17 / 6$ & 802000 \\
\hline $1 / 4$ & 692500 & $18 / 6$ & 802000 \\
\hline $1 / 5$ & 692500 & $19 / 6$ & 802000 \\
\hline $1 / 6$ & 692500 & $20 / 6$ & 802000 \\
\hline $1 / 7$ & 692500 & $21 / 6$ & 802000 \\
\hline $1 / 8$ & 692500 & $22 / 6$ & 802000 \\
\hline $1 / 9$ & 692500 & $23 / 6$ & 802000 \\
\hline $1 / 10$ & 692500 & $24 / 6$ & 802000 \\
\hline $1 / 11$ & 2500 & $25 / 6$ & 802000 \\
\hline $2 / 0$ & 692500 & $26 / 6$ & 802000 \\
\hline $2 / 1$ & 892500 & $27 / 6$ & 802000 \\
\hline $2 / 2$ & 692500 & & \\
\hline $2 / 3$ & 692500 & & \\
\hline $2 / 4$ & 692500 & & \\
\hline $2 / 5$ & 692500 & & \\
\hline $2 / 6$ & 692500 & & \\
\hline $2 / 7$ & 692500 & & \\
\hline $2 / 8$ & 692500 & & \\
\hline $2 / 9$ & 692500 & & \\
\hline $\begin{array}{l}2 / 10 \\
2 / 11\end{array}$ & & & \\
\hline $2 / 11$ & 692500 & & \\
\hline & & & \\
\hline
\end{tabular}


ENERGY-RELATED OATA:

NUMBER OF ENERGY TYPES $=3$

DOE energy price escalation rates filename: ENCOST95

DOE region (state code): 4 (WA)

DOE rate schedule type: Industrial

Underlying gen. inflation rate used with DOE rates: $0.00 \%$

ENERGY TYPE:

BASE ANNUAL CONSUMPTION:

UNITS:

PRICE PER UNIT (\$):

ANNUAL DEMAND CHARGE $(\$)$ : ESCALATION RATE METHOD:
(A) Electricity
$7,777,778$ kWh

0.026

0.00

DOE rates

0.43

$-0.23$

$-0.56$

$-0.26$

0.56

0.96

0.49

$-0.07$

0.07

$-0.13$

$-0.49$

$-0.33$

0.33

0.59

0.88

0.90

0.42

0.41

0.41

0.41

0.44

0.41

0.41

0.43

0.43

0.40

0.40

0.43

0.43
(B)

Residual 0 il Natural Gas $2.500 .000 \quad 2.540 .940$ Gallon

0.410

0.00

DOE rates

Therm

0.420

0.00

DOE rates

5.12

3.01

3.50

3.82

3.67

4.45

4.54

3.85

3.93

3.46

2.05

2.10

2.89

1.92

1.28

2.13

2.67

2.69

2.80

2.73

2.65

2.75

2.76

2.68

2.69

2.70

2.70

2.77

2.76

3.13

2.18

2.25

1.86

1.36

1.79

2.75

2. 16

1. 57

3. 19

2.22

1.85

4.03

2.98

1.70

2.03

2.08

2.03

1.99

2. 04

2.08

2.03

1.99

2.03

2.06

2.09

2.05

2.01

2.04 
ENERGY TYPE:

ENERGY USE INDEXES BY YEAR:

$\begin{array}{lr}1995 & 100.00 \\ 1996 & 100.00 \\ 1997 & 100.00 \\ 1998 & 12.66 \\ 1999 & 12.66 \\ 2000 & 12.66 \\ 2001 & 12.66 \\ 2002 & 12.66 \\ 2003 & 12.66 \\ 2004 & 12.66 \\ 2005 & 12.66 \\ 2006 & 12.66 \\ 2007 & 12.66 \\ 2008 & 12.66 \\ 2009 & 12.66 \\ 2010 & 12.66 \\ 2011 & 12.66 \\ 2012 & 12.66 \\ 2013 & 12.66 \\ 2014 & 12.66 \\ 2015 & 12.66 \\ 2016 & 12.66 \\ 2017 & 12.66 \\ 2018 & 12.66 \\ 2019 & 12.66 \\ 2020 & 12.66 \\ 2021 & 12.66 \\ 2022 & 12.66\end{array}$

100.00

100.00

100.00

0.00

0.00

0.00

0.00

0.00

0.00

0.00

0.00

0.00

0.00

0.00

0.00

0.00

0.00

0.00

0.00

0.00

0.00

0.00

0.00

0.00

0.00

0.00

0.00

0.00

0.00

0.00

0.00

100.00

100.00

100.00

100.00

100.00

100.00

100.00

100.00

100.00

100.00

100.00

100.00

100.00

100.00

100.00

100.00

100.00

100.00

100.00

100.00

100.00

100.00

100.00

100.00

100.00

G. 4 


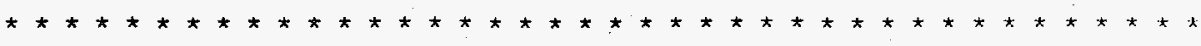

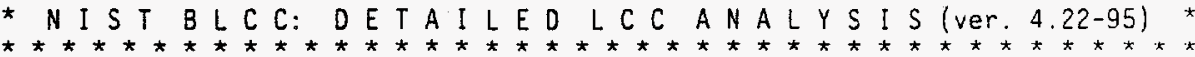

PART I - INITIAL ASSUMPTIONS AND COST DATA

Project alternative: Pvt. Newheat

Run date: 05-17-1995 15:18:55

Run type: General LCC Analysis--Non-Federal. No Taxes

Comment: 300A Dist Heat Sys-ESPC prvt O\&M 3yr Pay $28 y$ r std

Input data file: NEW2A.DAT. last modified: 05-17-1995/15:17:18

LCC output file: NEW2A.LCC, created: 05-17-1995/15:17:25

Base Date of Study: JAN 1995

Service Date: JAN 1995

Study period: $\quad 28.00$ years (JAN 1995 through OEC 2022)

Discount rate: $\quad 3.0 \%$ Real (exclusive of general inflation)

End-of-year discounting convention

INITIAL CAPITAL ASSET COSTS (NOT DISCOUNTED)

TOTAL FOR Existing Plt
Tota? Cost
TOTAL FOR New Heat PIt
TOTAL INITIAL CAPITAL ASSET COSTS

ENERGY-RELATED COSTS

\begin{tabular}{|c|c|c|c|c|c|c|}
\hline $\begin{array}{l}\text { Energy } \\
\text { Type }\end{array}$ & Units & $\begin{array}{l}\text { Units/ } \\
\text { Year }\end{array}$ & $\begin{array}{l}\text { Pricet } \\
\text { (\$/Unit) }\end{array}$ & $\begin{array}{l}\text { Energy } \\
\text { Ennual }\end{array}$ & $\begin{array}{l}\text { Cost -.-- } \\
\text { Demand }\end{array}$ & $\begin{array}{l}\text { Total } \\
\text { P.V. Cost }\end{array}$ \\
\hline $\begin{array}{l}\text { Electricity } \\
\text { Residual Oil } \\
\text { Natural Gas }\end{array}$ & $\begin{array}{l}\text { kWh } \\
\text { Gallon } \\
\text { Therm }\end{array}$ & $\begin{array}{l}7.777,778 \\
2.500 .000 \\
2.540,940\end{array}$ & $\begin{array}{l}\$ 0.026 \\
\$ 0.410 \\
\$ 0.420\end{array}$ & $\begin{array}{r}\$ 202,222 \\
\$ 1,025,000 \\
\$ 1,067,195\end{array}$ & $\begin{array}{l}\$ 0 \\
\$ 0 \\
\$ 0\end{array}$ & $\begin{array}{r}\$ 992.368 \\
\$ 3.143 .478 \\
\$ 23.734 .340\end{array}$ \\
\hline
\end{tabular}

+Price and annual cost are as of base date (not adjusted for price escalation)

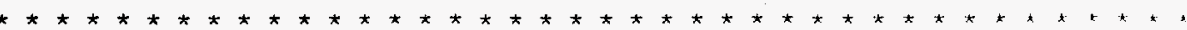

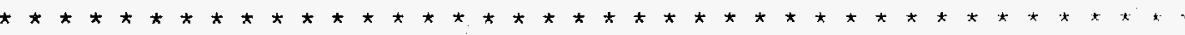


PART II - LIFE-CYCLE COST ANALYSIS

Discount Rate $=3.0 \%$ Real (exclusive of general inflation)

PROJECT ALTERNATIVE: Pvt. Newheat

RUN DATE: 05-17-1995/15:18:55

PRESENT VALUE
(1995 DOLLARS)
(1995 DOLLARS)

CASH REQUIREMENTS AS OF SERVICE DATE

$\$ \dot{0}$

$\$ 0$

OPERATING. MAINTENANCE \& REPAIR COSTS:

Existing PIt:

NON-ANNUALLY RECURRING COSTS

$\$ 24,408,010$

$\$ 1.300 .783$

New Heat Plt:

NON-ANNUALLY RECURRING COSTS

$\$ 12,970,560$

$\$ 691.244$

SUBTOTAL

$\$ 37.378 .568$

$\$ 1.992 .026$

ENERGY COSTS

$\$ 27.870 .180$

$\$ 1.485 .293$

REPLACEMENTS TO CAPITAL COMPONENTS

Existing Plt

New Heat P7t

SUBTOTAL

$\$ 17,010,010$

$-17.010 .010$

$\$ 17,010,010$

$\$ 906.519$

................

$\$ 906.519$

RESALE VALUE OF ORIG CAPITAL COMPONENTS Existing Plt

New Heat Plt

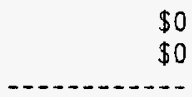

SUBTOTAL

$\$ 0$

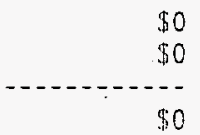

RESALE VALUE OF CAPITAL REPLACEMENTS

Existing Plt

New Heat Plt

$\begin{array}{r}\$ 0 \\ \$ 933,891 \\ \hline \$ 933,891\end{array}$

$$
\begin{array}{r}
\$ 0 \\
\$ 49.770 \\
\hline \$ 49.770 \\
\$ 4.334 .069
\end{array}
$$

SUBTOTAL

$\$ 81,324,872$

TOTAL LIFE-CYCLE PROJECT COST 


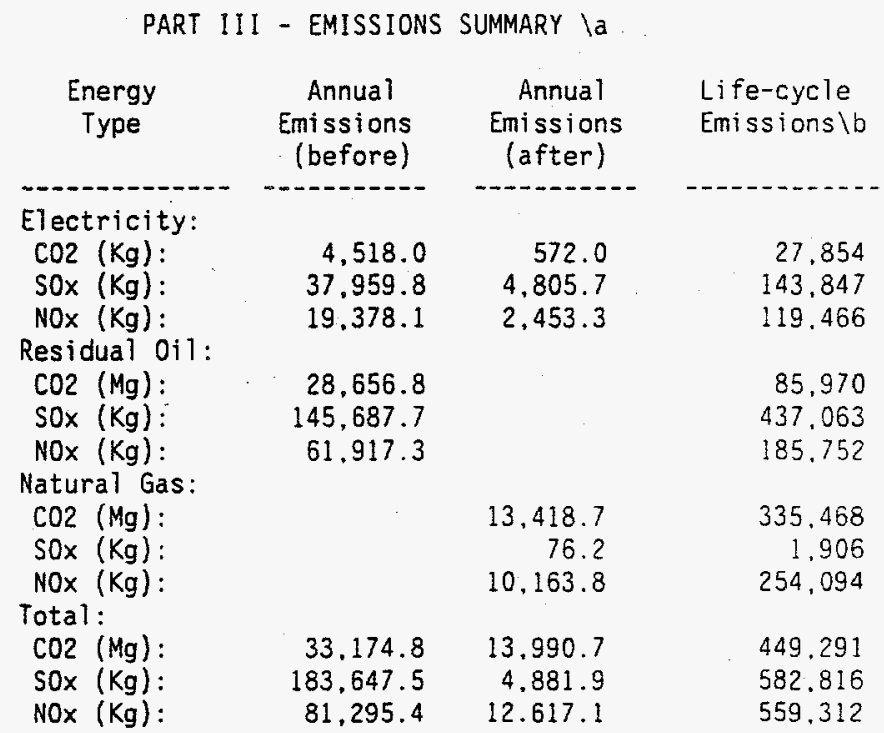

la Based on emission factors from file EMISSION.FIL

Ib Includes effects of annual energy usage indices, if used.

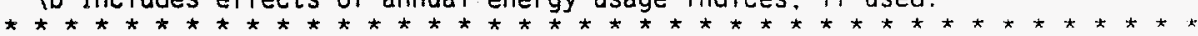




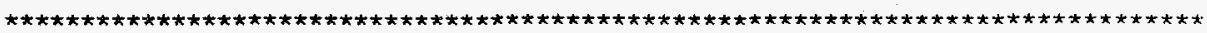

* N IST BLCC CASH FLOW ANALYS I S (version 4.22-95)*

PROJECT ALTERNATIVE: Pvt. Newheat

COMMENT: 300A Dist Heat Sys-ESPC prvt 0\&M 3yr Pay 28yr std

RUN DATE: 05-17-1995 15:19:10

INPUT DATA FILE: NEW2A.DAT. LAST MODIFIED 05-17-1995/15:17:18

STUDY PERIOD: $\quad 28.00$ YEARS (JAN 1995 THROUGH DEC 2022)

ANALYSIS TYPE: General LCC Analysis--Non-Federal. No Taxes

All costs in constant 1995 dollars (i.e., excluding general inflation)

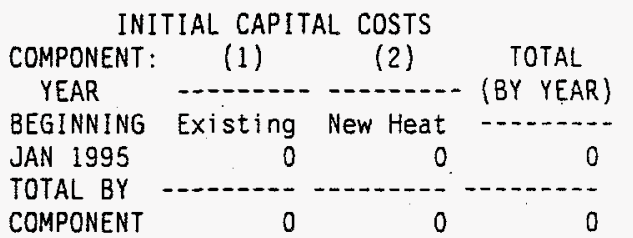

CAPITAL INVESTMENT COSTS

\begin{tabular}{|c|c|c|c|c|}
\hline $\begin{array}{c}\text { YEAR } \\
\text { BEGINNING }\end{array}$ & $\begin{array}{l}\text { INIT CAPITAL } \\
\text { INVESTMENT }\end{array}$ & $\begin{array}{l}\text { CAPITAL } \\
\text { REPLACEMENTS }\end{array}$ & $\begin{array}{l}\text { CAPITAL } \\
\text { DISPOSAL }\end{array}$ & $\begin{array}{l}\text { TOTAL CAP. } \\
\text { INVESTMENT }\end{array}$ \\
\hline - & - - - & ----1--- & - - & --n-n-n \\
\hline JAN 1995 & 0 & 0 & 0 & 0 \\
\hline JAN 1996 & 0 & 0 & 0 & 0 \\
\hline JAN 1997 & 0 & 0 & 0 & 0 \\
\hline JAN 1998 & 0 & $6.474,770$ & 0 & $6.474,770$ \\
\hline JAN 1999 & 0 & 6.474 .770 & 0 & 6.474 .770 \\
\hline JAN 2000 & 0 & $6,474,770$ & 0 & 6.474 .770 \\
\hline JAN 2001 & 0 & 0 & 0 & 0 \\
\hline JAN 2002 & 0 & 0 & 0 & 0 \\
\hline JAN 2003 & 0 & 0 & 0 & 0 \\
\hline JAN 2004 & 0 & 0 & 0 & 0 \\
\hline JAN 2005 & 0 & 0 & 0 & 0 \\
\hline JAN 2006 & 0 & 0 & 0 & 0 \\
\hline JAN 2007 & 0 & 0 & 0 & 0 \\
\hline JAN 2008 & 0. & 0 & 0 & 0 \\
\hline JAN 2009 & 0 & 0 & 0 & 0 \\
\hline JAN 2010 & 0 & 0 & 0 & 0 \\
\hline JAN 2011 & 0 & 0 & 0 & 0 \\
\hline JAN 2012 & 0 & 0 & 0 & 0 \\
\hline JAN 2013 & 0 & 0 & 0 & 0 \\
\hline JAN 2014 & 0 & 0 & 0 & 0 \\
\hline JAN 2015 & 0 & 0 & 0 & 0 \\
\hline JAN 2016 & 0 & 0 & 0 & 0 \\
\hline JAN 2017 & 0 & 0 & 0 & 0 \\
\hline JAN 2018 & 0 & 0 & 0 & 0 \\
\hline JAN 2019 & 0 & 0 & 0 & 0 \\
\hline JAN 2020 & 0 & 0 & 0 & 0 \\
\hline JAN 2021 & 0 & 0 & 0 & 0 \\
\hline JAN 2022 & 0 & 0 & 2.136 .674 & $-2,136,674$ \\
\hline TOTAL & 0 & $19,424,310$ & $2,136,674$ & 17.287 .636 \\
\hline
\end{tabular}


OPERATING-RELATED COSTS OURING SERVICE PERIOD:

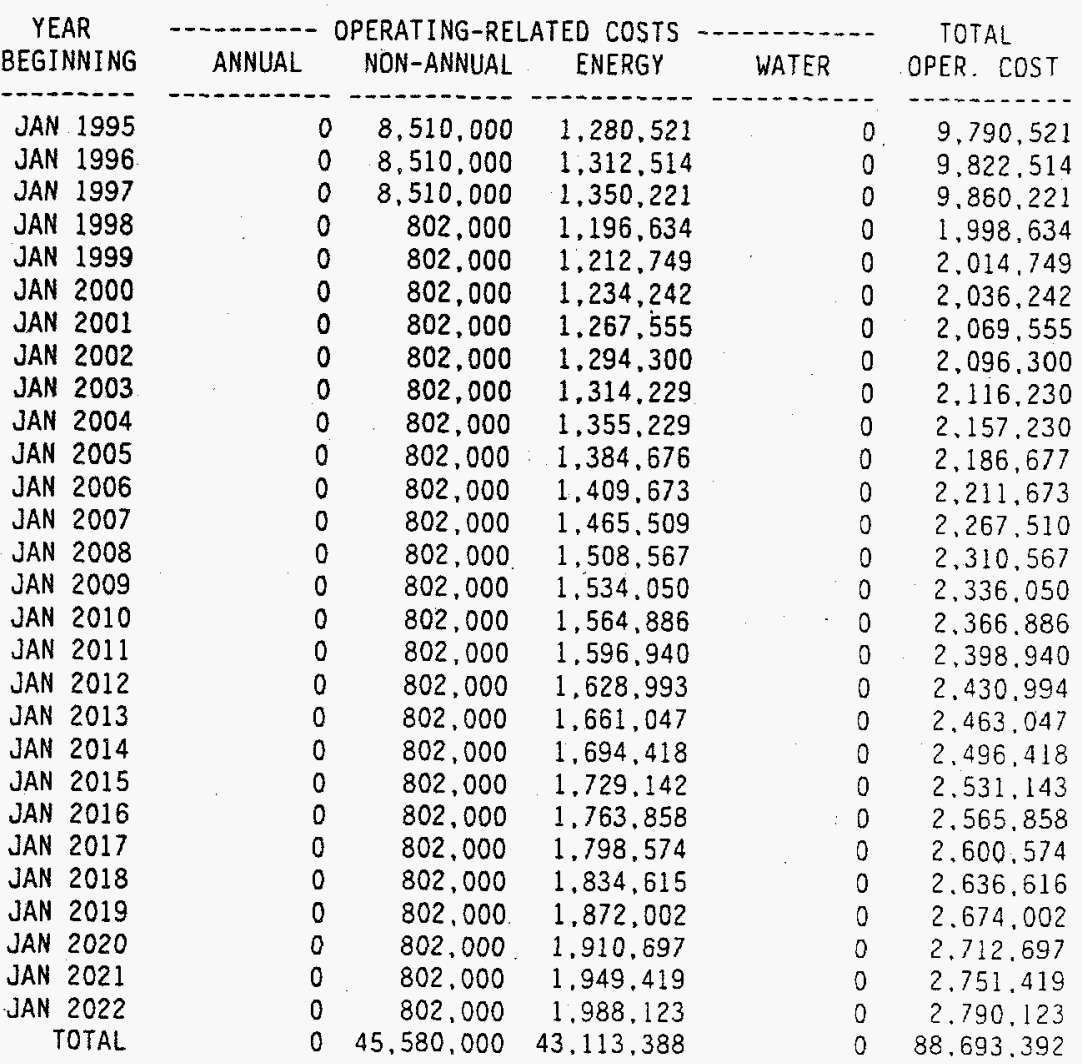


SUM OF ALL CASH FLOWS (showing residual value)

\begin{tabular}{|c|c|c|c|}
\hline $\begin{array}{c}\text { YEAR } \\
\text { BEGINNING }\end{array}$ & $\begin{array}{l}\text { CAPITAL } \\
\text { INVESTMENT }\end{array}$ & $\begin{array}{l}\text { OPERATING } \\
\text { COSTS }\end{array}$ & $\begin{array}{l}\text { TOTAL } \\
\text { COST }\end{array}$ \\
\hline - & $-1-1$ & $-1-1-1$ & $-\ldots$ \\
\hline JAN 1995 & 0 & $9,790,521$ & $9,790,521$ \\
\hline JAN 1996 & 0 & $9,822,514$ & 9.822 .514 \\
\hline JAN 1997 & 0 & $9,860,221$ & $9,860,221$ \\
\hline JAN 1998 & 6.474 .770 & $1,998,634$ & $8,473,404$ \\
\hline JAN 1999 & $6,474,770$ & $2,014,749$ & $8,489,519$ \\
\hline JAN 2000 & 6.474 .770 & $2,036,242$ & $8,511,012$ \\
\hline JAN 2001 & 0 & $2,069,555$ & $2.069,555$ \\
\hline JAN 2002 & 0 & $2,096,300$ & $2,096,300$ \\
\hline JAN 2003 & 0 & $2,116,230$ & $2,116,230$ \\
\hline JAN 2004 & 0 & $2,157,230$ & 2.157 .230 \\
\hline JAN 2005 & 0 & $2,186,677$ & $2,186,677$ \\
\hline JAN 2006 & 0 & $2,211,673$ & $2,211,673$ \\
\hline JAN 2007 & 0 & $2,267,510$ & $2,267,510$ \\
\hline JAN 2008 & 0 & $2,310,567$ & $2.310,567$ \\
\hline JAN 2009 & 0 & 2.336 .050 & $2,336,050$ \\
\hline JAN 2010 & 0 & $2,366.886$ & $2,366.886$ \\
\hline JAN 2011 & 0 & $2,398,940$ & $2,398,940$ \\
\hline JAN 2012 & 0 & $2,430,994$ & $2,430,994$ \\
\hline JAN 2013 & 0 & $2.463,047$ & $2.463,047$ \\
\hline JAN 2014 & 0 & $2,496,418$ & $2,496,418$ \\
\hline JAN 2015 & 0 & $2.531,143$ & $2,531,143$ \\
\hline JAN 2016 & 0 & $2,565,858$ & $2.565,858$ \\
\hline JAN 2017 & 0 & $2,600,574$ & $2,600,574$ \\
\hline JAN 2018 & 0 & $2,636,616$ & 2.636 .616 \\
\hline JAN 2019 & 0 & $2,674,002$ & $2,674,002$ \\
\hline JAN 2020 & 0 & $2,712,697$ & $2,712,697$ \\
\hline JAN 2021 & 0 & $2,751,419$ & $2,751,419$ \\
\hline JAN 2022 & -2.136 .674 & 2.790 .123 & 653.449 \\
\hline TOTAL & $17,287,636$ & $88,693,392$ & 105.981 .024 \\
\hline
\end{tabular}


SUM OF ALL CASH FLOWS (w/o showing residual value)

\begin{tabular}{|c|c|c|c|}
\hline $\begin{array}{c}\text { YEAR } \\
\text { BEGINNING }\end{array}$ & $\begin{array}{l}\text { CAPITAL } \\
\text { INVESTMENT }\end{array}$ & $\begin{array}{l}\text { OPERATING } \\
\text { COSTS }\end{array}$ & $\begin{array}{r}\text { TOTAL } \\
\text { COST }\end{array}$ \\
\hline 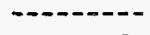 & 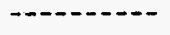 & $\ldots$ & \\
\hline $\begin{array}{l}\text { JAN } 1995 \\
\text { JAN } 1996\end{array}$ & $\begin{array}{l}0 \\
0\end{array}$ & $\begin{array}{l}9.790,521 \\
9.822,514\end{array}$ & $\begin{array}{l}9,790,521 \\
9,822,514\end{array}$ \\
\hline JAN 1997 & 0 & $9,860,221$ & $9,860,221$ \\
\hline JAN 1998 & $6,474,770$ & $1,998,634$ & $8,473,404$ \\
\hline JAN 1999 & $6,474,770$ & $2,014,749$ & $8,489,519$ \\
\hline JAN 2000 & $6,474,770$ & $2,036,242$ & $8,511,012$ \\
\hline JAN 2001 & 0 & $2,069,555$ & $2.069,555$ \\
\hline JAN 2002 & 0 & $2,096,300$ & $2,096,300$ \\
\hline JAN 2003 & 0 & $2,116,230$ & $2,116,230$ \\
\hline JAN 2004 & 0 & $2,157,230$ & 2.157 .230 \\
\hline JAN 2005 & 0 & $2,186,677$ & $2,186,677$ \\
\hline JAN 2006 & 0 & $2,211.673$ & $2,211.673$ \\
\hline JAN 2007 & 0 & $2,267,510$ & $2,267,510$ \\
\hline JAN 2008 & 0 & $2,310,567$ & $2,310,567$ \\
\hline JAN 2009 & 0 & $2,336,050$ & $2,336,050$ \\
\hline JAN 2010 & 0 & $2.366,886$ & $2,366,886$ \\
\hline JAN 2011 & 0 & $2,398,940$ & $2.398,940$ \\
\hline JAN 2012 & 0 & $2.430,994$ & $2,430,994$ \\
\hline JAN 2013 & 0 & $2,463.047$ & $2,463,047$ \\
\hline JAN 2014 & 0 & $2,496,418$ & $2,496,418$ \\
\hline JAN 2015 & 0 & 2.531 .143 & $2,531,143$ \\
\hline JAN 2016 & 0 & $2,565.858$ & $2.565,858$ \\
\hline JAN 2017 & 0 & $2,600,574$ & $2,600,574$ \\
\hline JAN 2018 & 0 & $2,636,616$ & $2,636,616$ \\
\hline JAN 2019 & 0 & $2.674,002$ & $2,674,002$ \\
\hline JAN 2020 & 0 & $2,712,697$ & $2,712.697$ \\
\hline JAN 2021 & 0 & $2,751,419$ & $2,751.419$ \\
\hline JAN 2022 & 0 & $2,790,123$ & 2.790 .12 \\
\hline & $19,424,310$ & $88,693,392$ & 1811770 \\
\hline
\end{tabular}

G.11 


\section{Appendix H}

Life-Cycle Cost Analysis for New Distributed Heating System, 28-Year Study Period and 10-Year Loan Repayment Period 
* N I S T B L C C: IN P U T D A T A L I.S T I N G (ver. 4.22-95).

FILE NAME: NEW2B

FILE LAST MODIFIED ON 05-17-1995/16:03:54

PROJECT ALTERNATIVE: Pvt. Newheat

COMMENT: $300 \mathrm{~A}$ Dist Heat Sys-ESPC prvt O8M 10yr Pay $28 \mathrm{yr}$ std

GENERAL DATA:

ANALYSIS TYPE: General LCC Analysis--Non-Federal, No Taxes

BASE DATE FOR LCC ANALYSIS: JAN 1995

STUDY PERIOD: 28 YEARS, O MONTHS

SERVICE DATE: JAN 1995

DISCOUNT AND INTEREST RATES ARE Real (exclusive of general inflation)

DISCOUNT RATE: $3.0 \%$

Escalation rates do not include general inflation

CAPITAL ASSET COST DATA:

NUMBER OF CAPITAL COMPONENTS: 3

COMPONENT NAME:

INITIAL COST (BASE YEAR \$)

EXPECTED ASSET LIFE (YRS/MTHS)

RESALE VALUE FACTOR

AVG PRICE ESC RATE(SERVICE PD)

NUMBER OF REPLACEMENTS

Existing $P 1 t$
0
$0 / 0$
$0.00 \%$
$0.00 \%$
0

0

New Heat Plt
0
$0 / 0$
$0.00 \%$
$0.00 \%$
8

More New Heat

REPLACEMENTS TO CAPITAL ASSETS:

REPLACEMENTS TO New Heat Plt:

REPLACEMENT NUMBER

YEARS/MONTHS FROM SERVICE DATE

INITIAL COST (BASE YEAR \$)

EXPECTED REPL.. LIFE (YRS/MTHS)

RESALE VALUE FACTOR

1
$3 / 6$
2.493 .450
$30 / 0$
$8.60 \%$

2
$4 / 6$
$2,493,450$
$29 / 0$
$8.60 \%$
3
$5 / 6$
$2,493,450$
$28 / 0$.
$8.60 \%$

2.493 .450

$27 / 0$

REPLACEMENTS TO New Heat Plt: REPLACEMENT NUMBER

YEARS/MONTHS FROM SERVICE DATE

INITIAL COST (BASE YEAR \$)

EXPECTED REPL. LIFE (YRS/MTHS)

RESALE VALUE FACTOR

5
$7 / 6$
$2.493,450$
$26 / 0$
$8.60 \%$

6
$8 / 6$
2.493 .450
$25 / 0$
$8.60 \%$
$9 / 6$
$2.493,450$
$24 / 0$
$8.60 \%$

$8.60 \%$

REPLACEMENTS TO More New Heat:

REPLACEMENT NUMBER

YEARS/MONTHS FROM SERVICE DATE

INITIAL COST (BASE YEAR \$)

EXPECTED REPL. LIFE (YRS/MTHS)

RESALE VALUE FACTOR

1
$11 / 6$
$2,493,450$
$22 / 0$
$8.60 \%$

2
$12 / 6$
$2.493,450$
$21 / 0$
$8.60 \%$

H. 1 
OPERATING, MAINTENANCE, ANO REPAIR COST DATA BY COMPONENT:

OST DATA BY COMPONENT:

$\begin{array}{lccc} & \text { COMP } 1 & \text { COMP } 2 & \text { COMP } 3 \\ \text { ANNUAL RECUR OMER COST (\$): } & 0 & 0 & 0 \\ \text { ESCALATION RATE FOR OM\&R: } & 0.00 \% & 0.00 \% & 0.00 \%\end{array}$

NON-AN RECURRING OMER COSTS (YRS/MTHS FROM SERVICE DATE; COST IN BASE YEAR \$): COMP 1 COMP 2 COMP 3

$Y / M \quad \operatorname{CosT} Y / M \quad \operatorname{COST} Y / M \quad \operatorname{COST}$

$0 / 1 \quad 692500 \quad 3 / 6 \quad 802000$

$0 / 2 \quad 892500 \quad 4 / 6 \quad 802000$

$0 / 3 \quad 692500 \quad 5 / 6 \quad 802000$

$0 / 4 \quad 692500 \quad 6 / 6 \quad 802000$

$0 / 5 \quad 692500 \quad 7 / 6 \quad 802000$

$0 / 6 \quad 692500 \quad 8 / 6 \quad 802000$

$0 / 7 \quad 692500 \quad 9 / 6 \quad 802000$

$0 / 8 \quad 692500 \quad 10 / 6 \quad 802000$

$0 / 9 \quad 69250011 / 6 \quad 802000$

$0 / 1069250012 / 6 \quad 802000$

$0 / 11692500 \quad 13 / 6 \quad 802000$

$1 / 0 \quad 692500 \quad 14 / 6 \quad 802000$

$\begin{array}{lllll}1 / 1 & 892500 & 15 / 6 & 802000\end{array}$

$1 / 2 \quad 69250016 / 6 \quad 802000$

$\begin{array}{llll}1 / 3 & 692500 & 17 / 6 & 802000\end{array}$

$1 / 4 \quad 692500 \quad 18 / 6 \quad 802000$

$\begin{array}{llll}1 / 5 & 692500 & 19 / 6 & 802000\end{array}$

$1 / 6 \quad 69250020 / 6 \quad 802000$

$1 / 7 \quad 692500 \quad 21 / 6 \quad 802000$

$1 / 8 \quad 692500 \quad 22 / 6 \quad 802000$

$1 / 9 \quad 692500 \quad 23 / 6 \quad 802000$

$1 / 1069250024 / 6 \quad 802000$

$1 / 11 \quad 692500 \quad 25 / 6 \quad 802000$

$2 / 0 \quad 692500 \quad 26 / 6 \quad 802000$

$2 / 1 \quad 892500 \quad 27 / 6 \quad 802000$

$2 / 2 \quad 692500$

$2 / 3 \quad 692500$

$2 / 4 \quad 692500$

$2 / 5 \quad 692500$

$2 / 6 \quad 692500$

$2 / 7 \quad 692500$

$2 / 8 \quad 692500$

$2 / 9 \quad 692500$

$2 / 10692500$

$2 / 11692500$

$3 / 0 \quad 692500$ 
ENERGY-RELATED DATA:

NUMBER OF ENERGY TYPES $=3$

DOE energy price escalation rates filename: ENCOST95

DOE region (state code): 4 (WA)

DOE rate schedule type: Industrial

Underlying gen. inflation rate used with DOE rates: $0.00 \%$

ENERGY TYPE:

BASE ANNUAL CONSUMPTION:

UNITS:

PRICE PER UNIT (\$):

ANNUAL DEMANO CHARGE (\$):

ESCALATION RATE METHOD:
(A) $7,777,778$ $\mathrm{kWh}$

0.026

0.00

DOE rates

\subsection{3}

$-0.23$

$-0.56$

$-0.26$

0.56

0.96

0.49

$-0.07$

0.07

$-0.13$

$-0.49$

$-0.33$

0.33

0.59

0.88

0.90

0.42

0.41

0.41

0.41

0.44

0.41

0.41

0.43

0.43

0.40

0.40

0.43

0.43
(B) $2.500 .000 \quad 2.540 .940$ Gallon

0.410

0.00

DOE rates

5.12

3.01

3.50

3.82

3.67

4.45

4.54

3.85

3.93

3.46

2.05

2.10

2.89

1.92

1.28

2.13

2.67

2.69

2.80

2.73

2.65

2.75

2.76

2. 68

2.69

2.70

2.70

2.77

2.76
(C)

Therm

0.420

0.00

DOE rates
3.13
2.18
2.25
1.86
1.36
1.79
2.75
2.16
1.57
3.19
2.22
1.85
4.03
2.98
1.70
2.03
2.08
2.03
1.99
2.04
2.08
2.03
1.99
2.03
2.06
2.09
2.05
2.01
2.04

2022

2023 
$\nabla H$

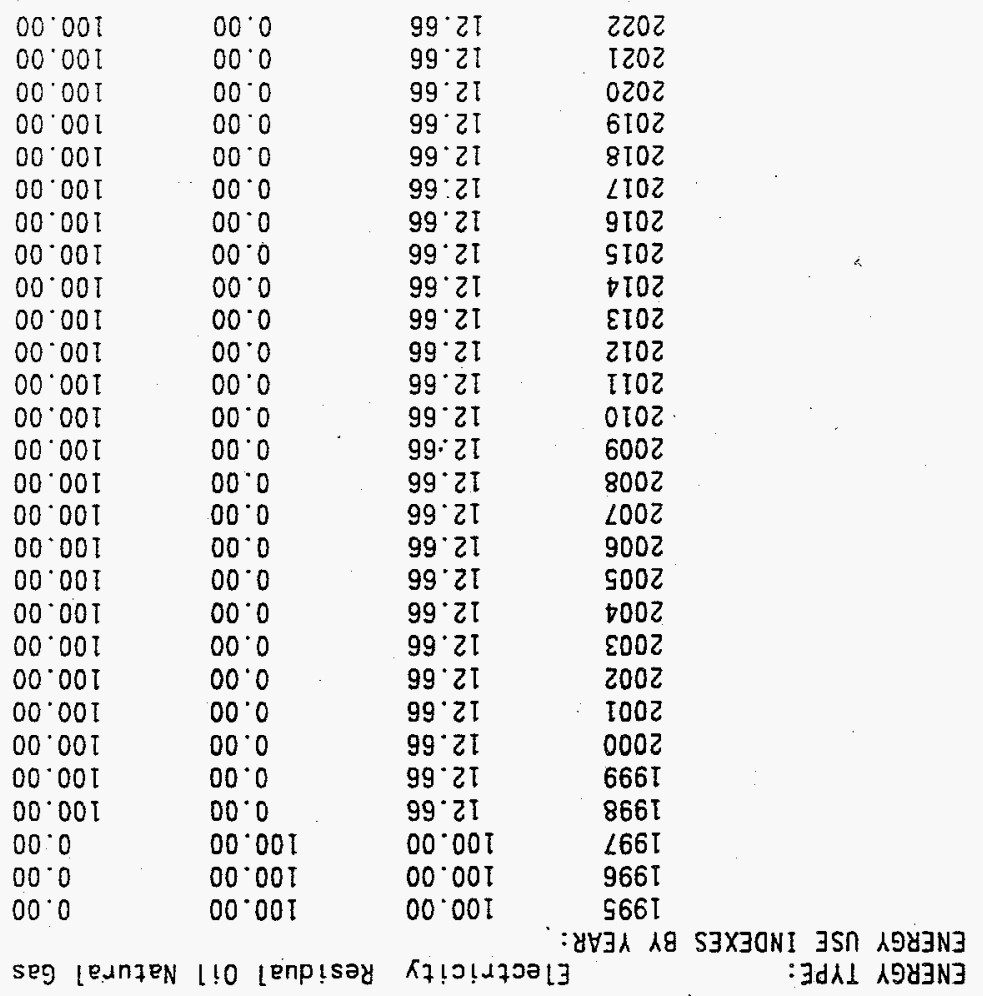




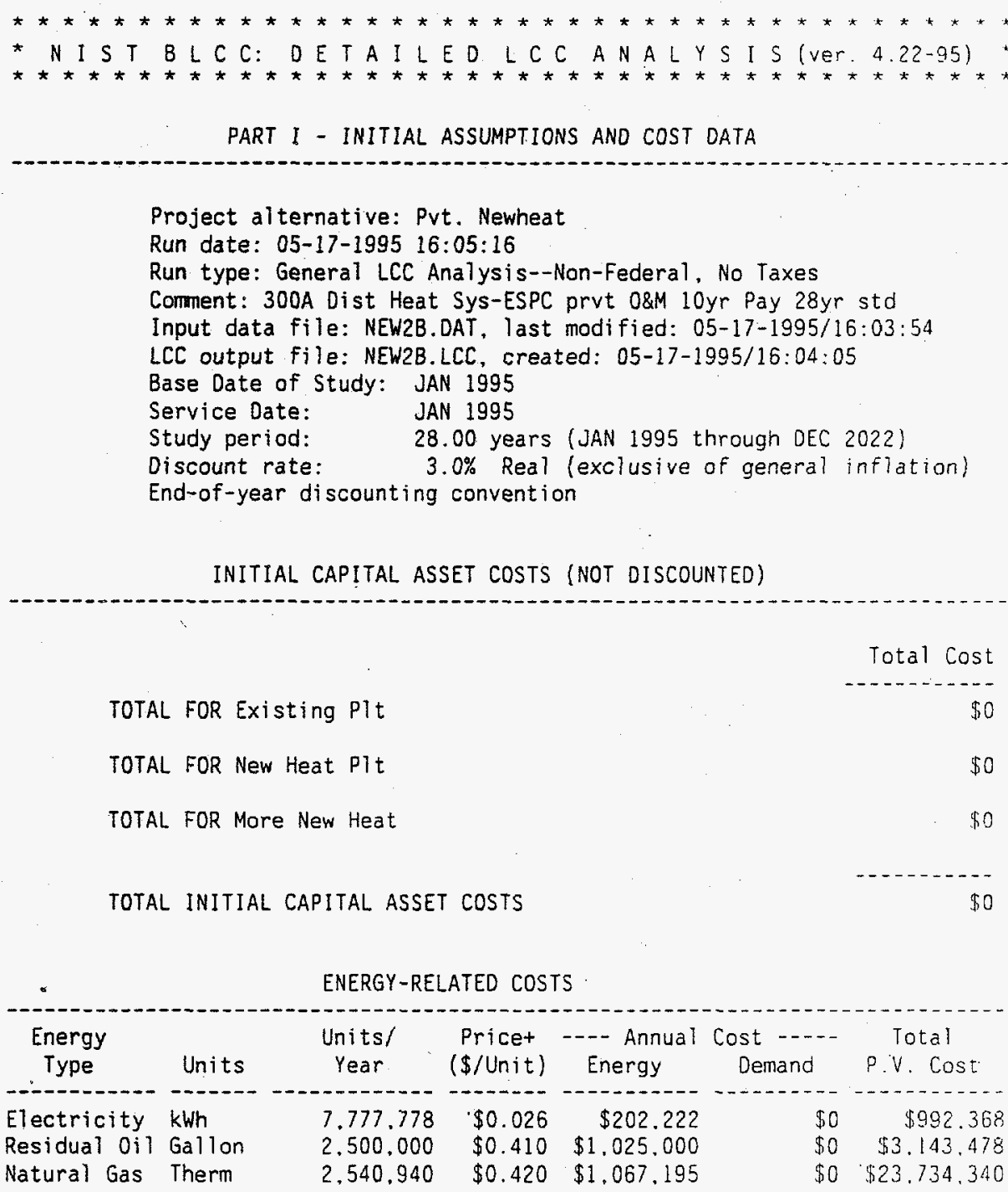

+Price and annual cost are as of base date (not adjusted for price escalation).

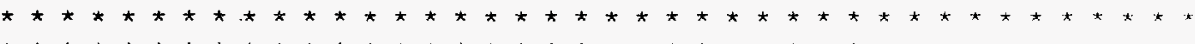


PART II - LIFE-CYCLE COST ANALYSIS

Discount Rate $=3.0 \%$ Real (exclusive of general inflation)

PROJECT ALTERNATIVE: Pvt. Newheat

RUN DATE: $05-17-1995 / 16: 05: 17$

PRESENT VALUE
(1995 DOLLARS)
(1995 DOLLARS)

CASH REQUIREMENTS AS OF SERVICE DATE

$\$ 0$

$\$ 0$

OPERATING, MAINTENANCE \& REPAIR COSTS:

Existing Plt:

NON-ANNUALLY RECURRING COSTS

$\$ 24,408,010$

$\$ 1,300.783$

New Heat Plt:

NON-ANNUALLY RECURRING COSTS

$\$ 12.970 .560$

$\$ 691.244$

More New Heat:

NON-ANNUALLY RECURRING COSTS

$\begin{array}{rr}\$ 0 & \$ 0 \\ \$ 37.378,568 & \$ 1.992 .026 \\ \$ 27,870,180 & \$ 1.485 .293\end{array}$

ENERGY COSTS

\begin{tabular}{rr}
$\$ 0$ & $\$ 0$ \\
$\$ 16,256.450$ & $\$ 866.359$ \\
$\$ 3.498 .095$ & $\$ 186.425$ \\
\hline$\$ 19.754 .550$ & $\$ 1.052 .785$
\end{tabular}

SUBTOTAL

$\$ 19,754,550$

$\$ 1.052 .785$

RESALE VALUE OF ORIG CAPITAL COMPONENTS

Existing Plt

New Heat PIt

More New Heat

SUBTOTAL

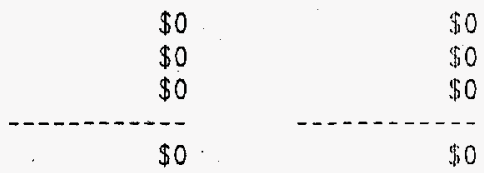

RESALE VALUE OF CAPITAL REPLACEMENTS

Existing Plt

New Heat P1t

More New Heat

$\$ 0$

$\$ 749,803$

$\$ 187,451$

SUBTOTAL

$\$ 937,254$

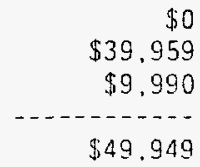

TOTAL LIFE-CYCLE PROJECT COST

$\$ 84.066 .048$

$\$ 4.480 .155$

H. 6 
PART III - EMISSIONS SUMMARY Ia

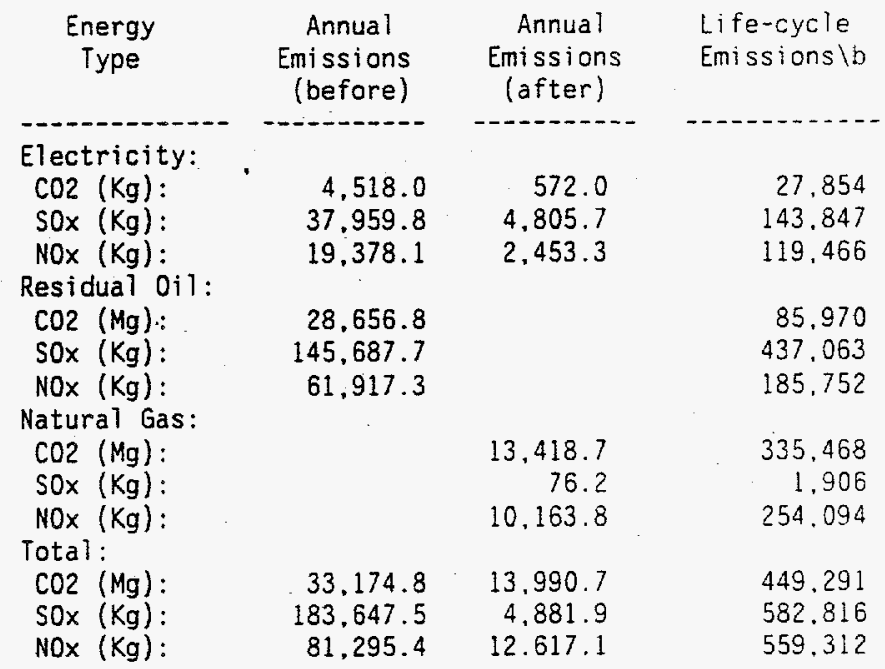

la Based on emission factors from file EMISSION.FIL

ib Inciudes effects of annual energy usage indices, if used. 


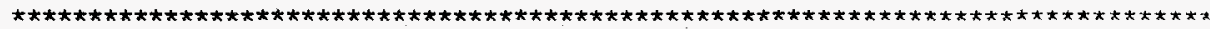

* N I S T B L C C C A S H F L O W W A N A L Y S I S (version 4. 22-95)*

PROJECT ALTERNATIVE: PVt. Newheat

COMMENT: $300 \mathrm{~A}$ Dist Heat Sys-ESPC prvt 0\&M 10yr Pay 28yr std

RUN DATE: 05-17-1995 16:05:31

INPUT DATA FILE: NEW2B.DAT, LAST MODIFIED 05-17-1995/16:03:54

STUDY PERIOD: 28.00 YEARS (JAN 1995 THROUGH DEC 2022)

ANALYSIS TYPE: General LCC Analysis--Non-Federal, No Taxes

A.1 costs in constant 1995 dollars (i.e., excluding general inflation)

\begin{tabular}{lrrrr} 
COMPONENT: & \multicolumn{2}{c}{ INITIAL CAPITAL COSTS } \\
(1) & (2) & (3) & $\begin{array}{c}\text { TOTAL } \\
\text { YEAR }\end{array}$ \\
BEGINNING & Existing & New Heat & More New & $(B Y$ YEAR) \\
JAN 1995 & 0 & 0 & 0 & 0 \\
TOTAL BY & 0 & 0 & 0 & 0 \\
COMPONENT & 0 & 0 & 0 & 0
\end{tabular}

CAPITAL INVESTMENT COSTS

\begin{tabular}{|c|c|c|c|c|}
\hline $\begin{array}{c}\text { YEAR } \\
\text { BEGINNING }\end{array}$ & $\begin{array}{l}\text { INIT CAPITAL } \\
\text { INVESTMENT }\end{array}$ & $\begin{array}{c}\text { CAPITAL } \\
\text { REPLACEMENTS }\end{array}$ & $\begin{array}{l}\text { CAPITAL } \\
\text { DISPOSAL }\end{array}$ & $\begin{array}{l}\text { TOTAL CAP. } \\
\text { INVESTMENT }\end{array}$ \\
\hline $10 N 1005$ & & 0 & & \\
\hline $\begin{array}{ll}\text { JAN } 1995 \\
\text { JAN } 1996\end{array}$ & $\begin{array}{l}0 \\
0\end{array}$ & $\begin{array}{l}0 \\
0\end{array}$ & $\begin{array}{l}0 \\
0\end{array}$ & $\begin{array}{l}0 \\
0\end{array}$ \\
\hline JAN 1997 & 0 & 0 & 0 & 0 \\
\hline JAN 1998 & 0 & $2,493.450$ & 0 & $2,493,450$ \\
\hline JAN 1999 & 0 & $2,493,450$ & 0 & $2.493,450$ \\
\hline JAN 2000 & 0 & $2,493.450$ & 0 & 2.493 .450 \\
\hline JAN 2001 & 0 & $2,493,450$ & 0 & $2,493,450$ \\
\hline JAN 2002 & 0 & $2,493,450$ & 0 & 2.493 .450 \\
\hline JAN 2003 & 0 & $2,493,450$ & 0 & $2,493,450$ \\
\hline JAN 2004 & 0 & $2,493.450$ & 0 & 2.493 .450 \\
\hline JAN 2005 & 0 & $2,493,450$ & 0 & 2.493 .450 \\
\hline JAN 2006 & 0 & $2,493,450$ & 0 & 2.493 .450 \\
\hline JAN 2007 & 0 & $2,493,450$ & 0 & $2,493,450$ \\
\hline JAN 2008 & 0 & 0 & 0 & 0 \\
\hline JAN 2009 & 0 & 0 & 0 & 0 \\
\hline JAN 2010 & 0 & 0 & 0 & 0 \\
\hline JAN 2011 & 0 & 0 & 0 & 0 \\
\hline JAN 2012 & 0 & 0 & 0 & 0 \\
\hline JAN 2013 & 0 & 0 & 0 & 0 \\
\hline JAN 2014 & 0 & 0 & 0 & 0 \\
\hline JAN 2015 & 0 & 0 & 0 & 0 \\
\hline JAN 2016 & 0 & 0 & 0 & 0 \\
\hline JAN 2017 & 0 & 0 & 0 & 0 \\
\hline JAN 2018 & 0 & 0 & 0 & 0 \\
\hline JAN 2019 & 0 & 0 & 0 & 0 \\
\hline JAN 2020 & 0 & 0 & 0 & 0 \\
\hline JAN 2021 & 0 & 0 & 0 & 0 \\
\hline JAN 2022 & 0 & 0 & $2,144,367$ & $-2,144.367$ \\
\hline TOTAL & 0 & $24,934,500$ & $2,144,367$ & 22.790 .132 \\
\hline
\end{tabular}

H. 8 
OPERATING-RELATED COSTS DURING SERVICE PERIOD:

\begin{tabular}{|c|c|c|c|c|c|}
\hline $\begin{array}{c}\text { YEAR } \\
\text { BEGINNING }\end{array}$ & ANNUAL & $\begin{array}{l}\text { OPERAT ING-RE } \\
\text { NON-ANNUAL }\end{array}$ & $\begin{array}{c}\text { ATED COSTS } \\
\text { ENERGY }\end{array}$ & WATER & $\begin{array}{l}\text { TOTAL } \\
\text { OPER. COS I }\end{array}$ \\
\hline ----- & & 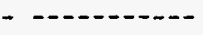 & 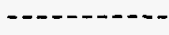 & & \\
\hline JAN 1995 & & $8,510,000$ & $1,280,521$ & 0 & 9.790 .521 \\
\hline JAN 1996 & & $8,510,000$ & $1,312,514$ & 0 & 9.822 .514 \\
\hline JAN 1997 & & $8,510,000$ & $1,350,221$ & 0 & $9,860.221$ \\
\hline JAN 1998 & & 802,000 & $1,196,634$ & 0 & 1.998 .634 \\
\hline JAN 1999 & & 802,000 & $1,212,749$ & 0 & $2,014,749$ \\
\hline JAN 2000 & & 802,000 & $1,234,242$ & 0 & 2.036 .242 \\
\hline JAN 2001 & & 802,000 & $1,267,555$ & 0 & $2,069,555$ \\
\hline JAN 2002 & & 802,000 & $1,294.300$ & 0 & $2,096,300$ \\
\hline JAN 2003 & & 802.000 & $1,314,229$ & 0 & $2,116,230$ \\
\hline JAN 2004 & & 802,000 & 1.355 .229 & 0 & $2,157,230$ \\
\hline JAN 2005 & 0 & 802,000 & $1,384,676$ & 0 & $2,186,677$ \\
\hline JAN 2006 & 0 & 802,000 & $1,409,673$ & 0 & $2,211,673$ \\
\hline JAN 2007 & & 802.000 & 1.465 .509 & 0 & $2,267,510$ \\
\hline JAN 2008 & & 802,000 & $1,508,567$ & 0 & $2,310.567$ \\
\hline JAN 2009 & & 802.000 & 1.534 .050 & 0 & 2.336 .050 \\
\hline JAN 2010 & & 802.000 & $1,564,886$ & 0 & 2.366 .886 \\
\hline JAN 2011 & & 802.000 & 1.596 .940 & 0 & $2,398,940$ \\
\hline JAN 2012 & & 802,000 & $1,628,993$ & 0 & $2,430.994$ \\
\hline JAN 2013 & 0 & 802.000 & 1.661 .047 & 0 & $2,463,047$ \\
\hline JAN 2014 & & 802,000 & 1.694 .418 & 0 & $2.496,418$ \\
\hline JAN 2015 & & 802.000 & $1,729,142$ & 0 & $2,531,143$ \\
\hline JAN 2016 & & 802,000 & $1.763,858$ & 0 & 2.565 .858 \\
\hline JAN 2017 & & 802.000 & $1,798,574$ & 0 & $2,600,574$ \\
\hline JAN 2018 & & 802.000 & $1.834,615$ & 0 & $2.636,616$ \\
\hline JAN 2019 & & 802.000 & $1,872,002$ & 0 & $2,674,002$ \\
\hline JAN 2020 & 0 & 802,000 & $1,910,697$ & 0 & 2.712 .697 \\
\hline JAN 2021 & 0 & 802,000 & $1,949,419$ & 0 & 2.751 .419 \\
\hline JAN 2022 & 0 & 802,000 & $1,988,123$ & 0 & $2.790,123$ \\
\hline TOTAL & 0 & 45.580 .000 & 43.113 .388 & 0 & 88.693 .392 \\
\hline
\end{tabular}


SUM OF ALL CASH FLOWS (showing residual value)

\begin{tabular}{|c|c|c|c|}
\hline $\begin{array}{c}\text { YEAR } \\
\text { BEGINNING }\end{array}$ & $\begin{array}{l}\text { CAPITAL } \\
\text { INVESTMENT }\end{array}$ & $\begin{array}{l}\text { OPERATING } \\
\text { COSTS }\end{array}$ & $\begin{array}{l}\text { TOTAL } \\
\text { COST }\end{array}$ \\
\hline & 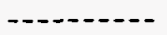 & -1 & \\
\hline JAN 1995 & 0 & 9.790 .521 & $9,790,52$ \\
\hline JAN 1996 & 0 & 9.822 .514 & \\
\hline JAN 1997 & 0 & $9.860,221$ & \\
\hline JAN 1998 & $2,493,450$ & 1.998 .634 & \\
\hline JAN 1999 & $2,493,450$ & & \\
\hline JAN 2000 & 2.493 .450 & & \\
\hline AN 2001 & 2,4 & & \\
\hline AN 2002 & 2,49 & 2.0 & \\
\hline JAN 2003 & 2.49 & 2.116 .230 & \\
\hline JAN 2004 & $2,493,450$ & $2,157,230$ & 4, \\
\hline IAN 2005 & $2,493,450$ & $2.186,677$ & 4.680 .1 \\
\hline JAN 2006 & $2,493,450$ & $2,211,673$ & $4,705,1$ \\
\hline AN 2007 & $2,493,450$ & $2.267,510$ & 4.7 \\
\hline AN 2008 & 0 & 2,310 & 2,3 \\
\hline AN 2009 & 0 & 2,3 & \\
\hline 2010 & 0 & & \\
\hline IAN 2011 & 0 & & \\
\hline N 2012 & 0 & 2,4 & 2.43 \\
\hline IN 2013 & 0 & 2,46 & 2,463 , \\
\hline AN 2014 & 0 & $2,496,418$ & 2,496 , \\
\hline N 2015 & 0 & $2,531,143$ & 2,531 , \\
\hline IN 2016 & 0 & $2,565,858$ & 2,565 , \\
\hline N 2017 & 0 & 2,60 & 2,600 , \\
\hline N 2018 & 0 & $2,636,616$ & 2,636 , \\
\hline 2010 & 0 & $2,674.002$ & 2,674, \\
\hline 2020 & 0 & $2,712,697$ & 2,712, \\
\hline & 0 & 2.751 .419 & $2.751,2$ \\
\hline 14 & 2.144 .367 & $2,790,123$ & \\
\hline & 22.790 .132 & $88,693,392$ & \\
\hline
\end{tabular}

H. 10 
SUM OF ALL CASH FLOWS (w/o showing residual vaiue)

\begin{tabular}{|c|c|c|c|}
\hline $\begin{array}{c}\text { YEAR } \\
\text { BEGINNING }\end{array}$ & $\begin{array}{l}\text { CAPITAL } \\
\text { INVESTMENT }\end{array}$ & $\begin{array}{l}\text { OPERATING } \\
\text { COSTS }\end{array}$ & $\begin{array}{r}\text { TOTAL } \\
\text { COST }\end{array}$ \\
\hline 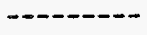 & 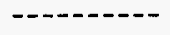 & $-2-1-2-1$ & \\
\hline JAN 1995 & 0 & $9,790,521$ & 9.790 .521 \\
\hline JAN 1996 & 0 & 9.822 .514 & 9.822 \\
\hline JAN 1997 & 0 & $9,860,221$ & 9.860 .221 \\
\hline JAN 1998 & $2,493,450$ & $1.998,634$ & $4.492,084$ \\
\hline JAN 1999 & $2,493,450$ & $2,014,749$ & 4.508 .199 \\
\hline JAN 2000 & $2,493,450$ & 2.036 .242 & 4.529 .69 \\
\hline JAN 2001 & $2,493,450$ & $2,069,555$ & $4,563,005$ \\
\hline JAN 2002 & $2,493,450$ & $2,096,300$ & 4.589 .750 \\
\hline JAN 2003 & 2.493 .450 & $2,116,230$ & $4,609.680$ \\
\hline JAN 2004 & $2,493,450$ & $2,157,230$ & $4,650,680$ \\
\hline JAN 2005 & $2,493,450$ & $2,186,677$ & $4,680,127$ \\
\hline JAN 2006 & $2,493,450$ & $2,211,673$ & $4,705,123$ \\
\hline JAN 2007 & $2,493,450$ & $2,267,510$ & $4.760,960$ \\
\hline JAN 2008 & 0 & $2,310,567$ & $2,310,567$ \\
\hline JAN 2009 & 0 & $2,336,050$ & $2,336,050$ \\
\hline JAN 2010 & 0 & 2.366 .886 & $2,366,886$ \\
\hline JAN 2011 & 0 & 2.398 .940 & 2.398 .940 \\
\hline JAN 2012 & 0 & $2.430,994$ & $2,430,994$ \\
\hline JAN 2013 & 0 & 2.463 .047 & $2,463,047$ \\
\hline JAN 2014 & 0 & $2,496,418$ & $2.496,418$ \\
\hline JAN 2015 & 0 & $2.531,143$ & $2,531,143$ \\
\hline JAN 2016 & 0 & $2,565,858$ & 2.565 .858 \\
\hline JAN 2017 & 0 & $2.600,574$ & $2,600,574$ \\
\hline JAN 2018 & 0 & $2,636,616$ & $2,636,616$ \\
\hline JAN 2019 & 0 & 2.674 .002 & 2.674 .002 \\
\hline JAN 2020 & 0 & $2,712,697$ & $2,712,697$ \\
\hline JAN 2021 & 0 & $2,751,419$ & $2,751.419$ \\
\hline JAN 2022 & 0 & $2.790,123$ & $2,790,123$ \\
\hline TOTAL & $24,934,500$ & $88,693,392$ & $13,627.89$ \\
\hline
\end{tabular}




\section{Distribution}

No. of

Copies

\section{OFFSITE}

2 DOE/Office of Scientific and

Technical Information

\section{ONSITE}

18 DOE Richland Operations Office

B. L. Ayers (5)

J. A. Broderick

J. A. Frey

T. L. Kehrli (5)

J. E. Mecca

R. M. Rosselli

W. A. Rutherford

T. O. Schmeeckle

W. A. White

J. W. Wiley

Westinghouse Hanford Company

J. R. Knight

8 ICF-Kaiser Hanford

J. L. Day

H. L. Debban (5)

W. S. Dunnivant

R. E. Piippo
H6-30

L6-79

A7-80

G3-18

K8-50

G3-18

R3-78

K8-50

A5-51

G3-18

G3-18

K8-50

H4-19

G3-04

G3-10
No. of

Copies

42 Pacific Northwest Laboratory

W. J. Apley

P8-30

T. J. Baranauskas

$\mathrm{K} 1-70$

M. J. Berman (5)

P7-63

V. W. Briggs, Jr.

P7-63

J. E. Burris

P7-63

T. D. Chikalla

P7-75

M. D. Conger

K3-07

E. R. Gerk

K. J. Gaither

J. C. Hail

P7-63

P7-70

P7-70

R. J. McFadzean K1-70

M. E. Olson

P7-63

N. J. Olson (10)

G. B. Parker

K9-89

K9-62

K1-73

K1-45

K8-18

P7-60

K1-52

G. L. Work

JTA Roberts

S. A. Weakley (5)

Publishing Coordination

Technical Report Files (5)

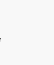

